
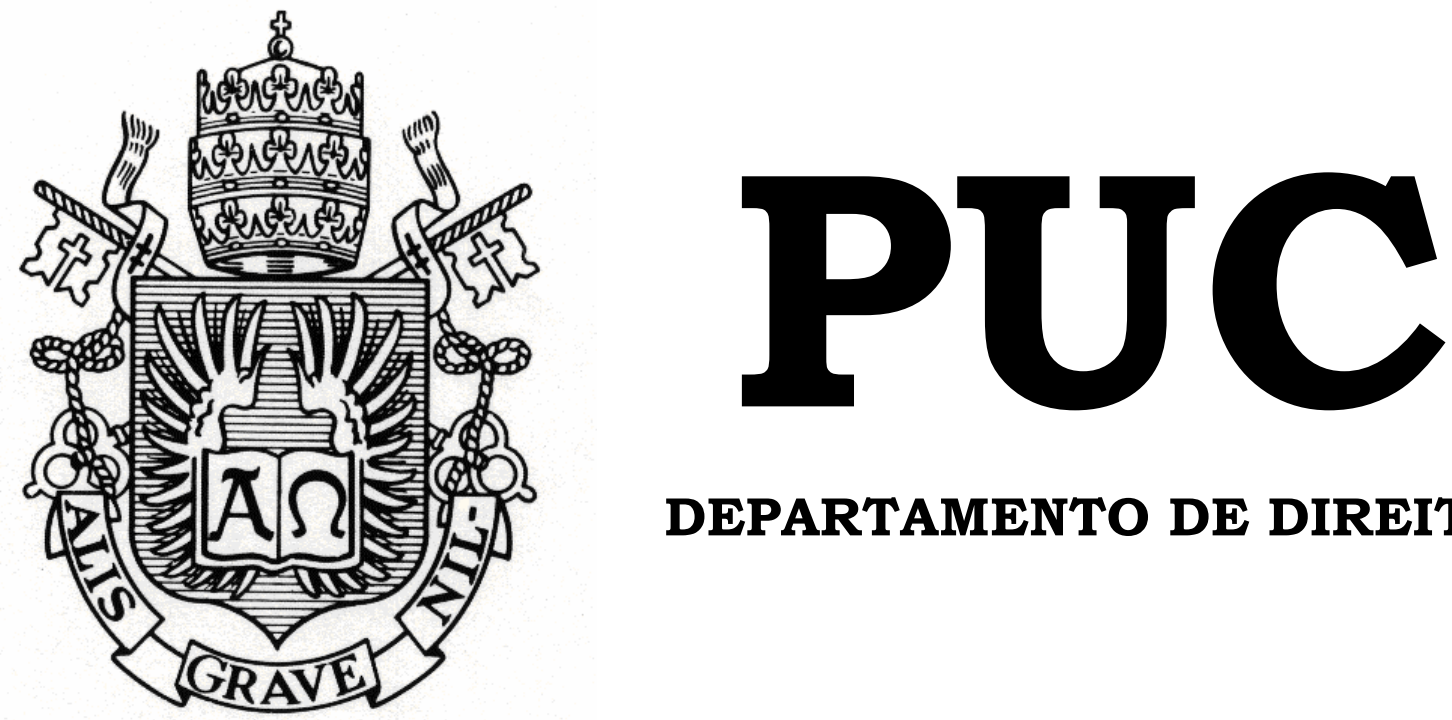

DEPARTAMENTO DE DIREITO

\title{
UMA HIPÓTESE DE COLISÃO DE PRINCÍPIOS NA AÇÃO NEGATÓRIA DE PATERNIDADE
}

por

RENATA DANTAS VILELA

ORIENTADORA:

Prof ${ }^{a}$. Dr ${ }^{a}$. Maria Celina Bodin de Moraes

2005.1 
PONTIFÍCIA UNIVERSIDADE CATÓLICA DO RIO DE JANEIRO

RUA MARQUÊS DE SÃO VICENTE, 225 - CEP 22453-900

RIO DE JANEIRO - BRASIL

\title{
UMA HIPÓTESE DE COLISÃO DE PRINCÍPIOS NA AÇÃO NEGATÓRIA DE PATERNIDADE
}

\author{
por \\ RENATA DANTAS VILELA
}

Monografia apresentada ao Departamento de Direito da Pontificia Universidade Católica do Rio de Janeiro (PUC-Rio) como requisito parcial para a obtenção do Título de Bacharel em Direito.

Orientador(a): Prof $^{a}$. Dr ${ }^{\mathrm{a}}$. Maria Celina Bodin de Moraes

2005.1 
Às minhas filhas Letícia e Luana, dedico este trabalho como tudo na minha vida. 


\section{AGRADECIMENTOS}

Embora esta monografia não tenha sido o meu primeiro rito de passagem no mundo acadêmico, foi sem dúvida o mais importante. O recomeçar pela própria escolha, talvez seja tão difícil quanto o recomeçar por não ter outra opção.

Pelas próprias circunstâncias em que cursei esta faculdade, chegar até este momento, significa muito. Significa ultrapassar o primeiro rito de passagem para o ingresso neste novo mundo profissional que escolhi.

O etnocentrismo é uma característica inerente ao ser humano, que insiste em julgar o outro através de seus próprios modelos e valores. Mas o mundo jurídico nos desafia o tempo todo ao exercício da relativização. Não exige que nos tornemos antropólogos, mas exige que ao menos consigamos olhar o outro através de seus próprios valores e dentro do contexto em que este se insere.

De fato, para muitos, a diferença é ameaçadora por que atinge a sua própria identidade cultural. Mas não se pode esquecer que a cultura opera apenas como uma mediadora entre o ser humano e a sua realidade. Logo, cada ser humano através de sua cultura constrói uma realidade diferente, demonstrando que não existe apenas uma realidade objetiva, mas diferentes realidades que compõem um mesmo universo. É a partir desse "estranhamento" em relação ao outro que iniciamos o ponto de partida para que consigamos sair de nós mesmos, e percebermos que as "verdades" da vida são muito menos uma questão de essência e muito mais uma questão de posição.

Esta é apenas uma das grandes qualidades da minha orientadora, ser uma antropóloga por natureza. Justamente por saber orientar sem conduzir, conseguindo instigar em todos nós o exercício do respeito à diferença.

Por isso, primeiramente, quero agradecer à Profa. Maria Celina Bodin de Moraes, não só pela orientação nesta monografia e pela grande amizade, mas, também, por ter aberto para mim a porta desse novo mundo, quando um dia, almoçando no antigo "Marangone", nesta faculdade, onde eu ainda cursava o $I A G$-master, me apoiou na difícil decisão de recomeçar, quando então resolvi me inscrever na Faculdade de Direito.

Agradeço ainda aos queridos amigos e brilhantes Professores Caitlin Mulholland e Marcelo Calixto por terem me dado a oportunidade de compartilhar com eles suas teses de mestrado, suas idéias e ensinamentos, me introduzindo ao universo da pesquisa jurídica. 
À Profa. Ana Luíza Maia Nevares pela paciência em debater este tema que tanto me atormentava, me trazendo de volta ao caminho, quando perdida, eu estava quase saindo dele.

À Profa. Rose Melo Vencelau Meireles pela excelente tese de mestrado sobre o elo perdido da filiação que foi a "musa inspiradora", além de substrato para a execução desta.

Ao querido amigo e defensor público Gilvan Teixeira Lima pelos ensinamentos e pelo convívio, tornando a dura realidade da defensoria tão prazerosa, conseguindo extrair sempre o melhor de nós.

Às queridas amigas Daniele Teixeira, Luciana Losada e Márcia Alvarenga pelo incentivo, sugestões, material bibliográfico, enfim, pela amizade e apoio em todos os sentidos.

Aos meus pais pela dedicação, presença e amor constantes, compartilhando de todas as minhas decisões.

Aos meus sogros Lélio e Alda Multedo por me receberem como uma filha, torcendo por cada conquista por mim alcançada.

Ao meu amor Fábio Multedo, por estar sempre ao meu lado, me fortalecendo para trilhar este caminho. 


\section{RESUMO}

O presente estudo tem como objetivo analisar os efeitos da ação negatória da paternidade no estado de filiação, tendo em vista que o $\mathrm{CC} / 2002$ optou, de forma diametralmente oposta ao CC/1916, pela ausência de prazo decadencial para a contestação da paternidade pelo pai presumido. Sob essa perspectiva, é primordial destacar que o tema se estrutura sob a ótica dos interesses do filho, diante da possibilidade de ter seu status desconstituído por outrem. Antes de abordarmos a ação ora em análise, trataremos dos critérios que fundamentam o vínculo paterno-filial, enfocando as realidades - jurídica, biológica e afetiva -, analisando, com destaque, o conceito de posse de estado de filho, por ser este fundamental quando ocorre o confronto entre estes critérios. Prosseguindo, procuramos diferenciar as ações de estado afirmativas das negativas, para então analisarmos com mais profundidade a ação negatória de paternidade. Ao final, objetivamos despertar a consciência da necessidade de reformulação das normas infraconstitucionais reguladoras das ações negativas de paternidade, uma vez ser imprescindível que o interesse da norma leve em conta os princípios constitucionais que informam todo o ordenamento jurídico, para que sua aplicação se dê em plena conformidade com os valores fundamentais em que a Constituição se baseia. 


\section{SUMÁRIO}

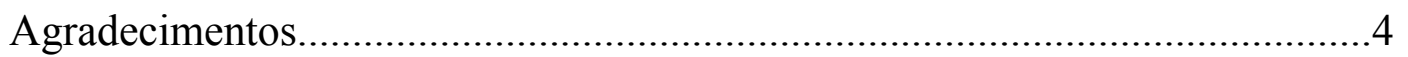

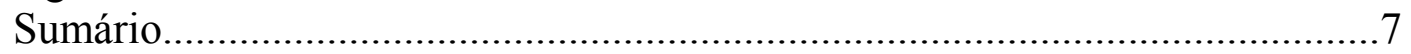

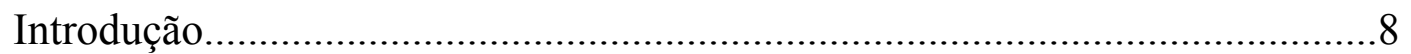

1. A Família fundada na dignidade da pessoa humana e no melhor interesse dos

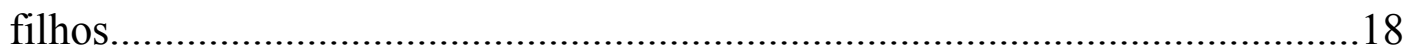

1.1 A consagração da dignidade humana como fundamento da República

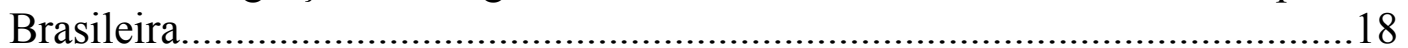

$1.2 \mathrm{O}$ princípio do melhor interesse da criança e do adolescente como desdobramento do princípio da dignidade humana.............................................25

$1.3 \mathrm{O}$ novo paradigma do conceito de família e o instituto da filiação...............30

2. Os critérios de estabelecimento da filiação: as realidades jurídica, biológica

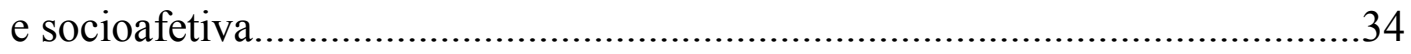

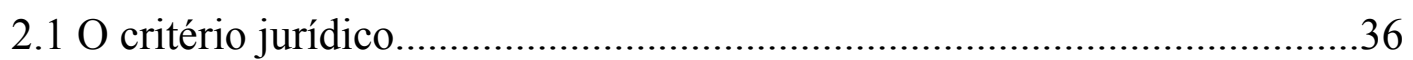

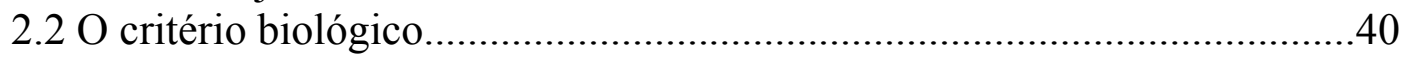

$2.3 \mathrm{O}$ critério afetivo e o conceito de posse de estado de filho...........................46

3. A contestação da paternidade...................................................................52

3.1 Das ações que versam sobre o estado da pessoa..........................................53

3.2 Das ações que viabilizam a contestação da paternidade................................55

3.2.1 Da ação negatória de paternidade.........................................................59

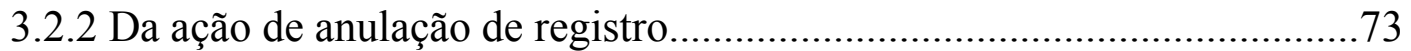

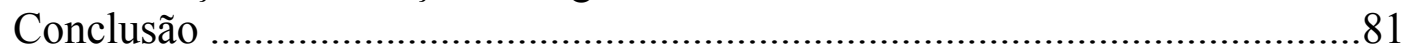

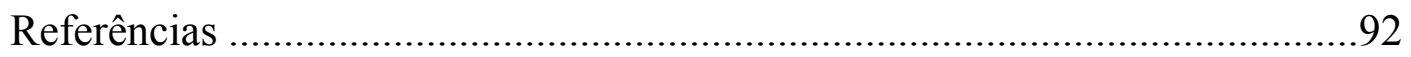




\title{
INTRODUÇÃO
}

\author{
"Conheces o nome que te deram, \\ não conheces o nome que tens. \\ Livro das Evidências". \\ José Saramago,Todos os Nomes.
}

Surpreendem-se aqueles que resolvem se debruçar sobre o tema da filiação no direito brasileiro com a descoberta de um terreno doutrinário fértil e avançado, além de uma jurisprudência rica e diversa. Mas as surpresas não param por aí. Nosso ordenamento jurídico revela grande preocupação com a promoção da dignidade da pessoa humana e a proteção dos direitos do filho, principalmente se comparado com outros sistemas jurídicos da mesma família romano-germânica. ${ }^{1}$

De fato, no Brasil há uma legislação em total sintonia com os direitos humanos da atualidade, marcada por uma norma inovadora que reuniu em seu Estatuto todo o direito especial da criança e do adolescente, disciplinando, com

\footnotetext{
${ }^{1}$ Assim destaca a Professora Maria Celina Bodin de Moraes: “o ordenamento jurídico brasileiro, em comparação com outros ordenamentos do sistema romano-germânico caracteriza-se pelo avanço na proteção dos direitos dos filhos". ("Recusa à realização do exame de DNA na investigação de paternidade e direitos da personalidade". In: A nova família: problemas e perspectivas, (coord.) Vicente Barreto, Renovar, 1997, p. 179)
} 
precisão, os direitos e garantias do menor, buscando conferir maior efetividade aos princípios insculpidos na Constituição Federal de $1988{ }^{2}$

Ainda que críticas possam ser feitas em relação ao Código Civil de 2002 nesta matéria, no geral, o ordenamento jurídico nacional caracteriza-se por um progresso digno de aplausos, principalmente dirigidos ao legislador constituinte de 1988.

A Constituição de 1988 modificou o paradigma do conceito de família no Direito brasileiro. A família valorizada como instituição, acima dos interesses de seus integrantes, cede lugar para uma família que deixa de ter um valor intrínseco, passando a merecer proteção apenas como instrumento de promoção da dignidade de seus membros e da personalidade dos filhos, priorizados em nossa legislação como pessoas humanas em desenvolvimento e por isso merecedores de uma proteção integral. ${ }^{3}$

$\mathrm{O}$ art. 226, caput do Texto de 88 dispõe que "a família, base da sociedade, tem especial proteção do Estado", especificando em seu $\S 8^{\circ}$ a forma como a família deve ser tutelada, estabelecendo que "o Estado assegurará a assistência à família na pessoa de cada um dos que a integram, criando mecanismos para coibir a violência no âmbito de suas relações”.

É esse o sentido da família contemporânea, destacado por Pietro Perlingieri: “A família, como formação social, é garantida pela Constituição

\footnotetext{
${ }^{2}$ Lei 8.069 de 13 de Julho de 1990 (Estatuto da Criança e do Adolescente)

${ }^{3}$ Maria Celina Bodin de Moraes destaca que o legislador constituinte de 1988 especificou a forma de tutela que à família deve ser concedida "não se garantindo mais proteção à instituição familiar a despeito ou acima dos interesses dos indivíduos que a compõem". ("O Direito Personalíssimo à Filiação e a Recusa ao Exame de DNA: Uma Hipótese de Colisão de Direitos Fundamentais”. In: Revista Forense, vol. 343, 1998, p. 161.) No mesmo sentido, Gustavo Tepedino ressalta que a família deve ser vista como um "núcleo intermediário de desenvolvimento da personalidade dos filhos e de promoção da dignidade de seus integrantes". ("A disciplina civil-constitucional das relações familiares". In: Temas de direito civil, $3^{\mathrm{a}}$ ed. Atual. Rio de Janeiro: Renovar, 2004, p. 398 e 399).
} 
não como portadora de um interesse superior e superindividual, mas, sim, em função da realização das exigências humanas, como lugar onde se desenvolve a pessoa".

Quanto ao instituto da filiação não poderia ter sido diferente. Temos aqui um marco histórico, com a adoção de um sistema único de tratamento aos filhos, através da consagração do princípio da isonomia que proíbe qualquer forma de discriminação, independentemente da origem da filiação. ${ }^{5}$ Nesse contexto, podemos inferir a subjacente intenção do legislador constituinte em realizar uma nítida separação entre conjugalidade e parentalidade.

Além disso, como já destacado, priorizou-se a proteção integral dos direitos da criança e do adolescente, como o direito à paternidade, à dignidade, ao conhecimento de sua origem genética, dentre outros, ${ }^{6}$ prevendo o Estatuto da Criança e do Adolescente, em seu artigo 27, que "o reconhecimento do estado de filiação é direito personalíssimo, indisponível e imprescritível”.

A Constituição de 88 valorizou mais do que nunca os laços de afeto nas relações familiares, ${ }^{7}$ comprovando a importância de uma abordagem

\footnotetext{
${ }^{4}$ Pietro Perlingieri. Perfis do Direito Civil: Introdução ao Direito Civil Constitucional, (trad. Maria Cristina de Cicco). $2^{\text {a }}$ ed. Rio de Janeiro: Renovar, 2002, p. 243.

${ }^{5} \mathrm{O}$ art. 227, parágrafo $8^{\circ}$ da $\mathrm{CF} / 88$ dispõe: "Os filhos, havidos ou não da relação do casamento, ou por adoção, terão os mesmos direitos e qualificações, proibidas quaisquer designações discriminatórias relativas à filiação". Como ressalta M.C. Bodin de Moraes (Recusas à realização do exame de DNA na investigação de paternidade e direitos da personalidade, cit., p. 179) "Assim é que, no Brasil, ao contrário do que ocorre em muitos outros países, são reconhecíveis, sem qualquer restrição, não apenas os filhos adulterinos como também os incestuosos, tendo sido vitorioso o argumento ético político de que a proteção da pessoa do filho deve justamente independer do tipo de relação existente entre seus pais".

${ }^{6} \mathrm{O}$ art. 227, caput da $\mathrm{CF} / 88$ dispõe: "É dever da família, da sociedade e do Estado assegurar à criança e ao adolescente com absoluta prioridade, o direito à saúde, à alimentação, à educação, ao lazer, à profissionalização, à cultura, à dignidade, ao respeito, à liberdade e à convivência familiar e comunitária, além de colocá-los a salvo de toda forma de negligência, discriminação, exploração, violência, crueldade e opressão".

${ }^{7}$ Assim ressalta Rose Melo Vencelau ( $O$ elo perdido da filiação: entre a verdade jurídica, biológica e afetiva no estabelecimento do vínculo paterno-filial. Rio de Janeiro: Renovar, 2004, p.114):
} 
interdisciplinar no estudo do direito de família. ${ }^{8}$ Sob essa perspectiva, quanto ao instituto da filiação, a realidade sócio-afetiva tem merecido especial atenção dos estudiosos, principalmente diante da consciência de que somente os laços afetivos são capazes de determinar as verdadeiras relações humanas.

Esse novo paradigma irradiou-se por todo o ordenamento jurídico, impondo uma releitura da legislação infraconstitucional à luz da Constituição, bem como a necessidade premente da análise das leis posteriormente promulgadas, buscando interpretá-las de acordo com os princípios constitucionais ora vigentes. ${ }^{9}$

Nesse cenário é que se insere o objeto desta pesquisa, que propõe uma reflexão, sob a ótica civil-constitucional, da imprescritibilidade conferida à ação negatória da paternidade pelo art. 1601 do Código Civil de $2002^{10}$,

“Atualmente, a Constituição de 1988 favorece o encontro de outros fundamentos para a distinção entre o fato de gerar e o ato de ser pai. Ao igualar os filhos havidos ou não da relação de casamento no art. 227, $\S 6^{\circ}$, a Carta Magna privilegia o critério sanguíneo, mas, também, os laços afetivos, na medida em que não permite discriminações. A afetividade é princípio jurídico presente no Direito de Família constitucional, uma vez que iguala os filhos biológicos aos adotivos, com respeito à escolha afetiva e protege como entidades familiares outras, como a união estável e a família monoparental cujo vínculo fundante é o da afetividade". No mesmo sentido ressalta Ana Luíza Maia Nevares (A tutela sucessória do cônjuge e do companheiro na legalidade constitucional. Rio de Janeiro: Renovar, 2004, p.74): "A partir da concepção instrumental de família, valorizando a pessoa de seus membros $\left(\mathrm{CF} / 88\right.$, art. $1^{\circ}$, III e art. $226, \S 8^{\circ}$ ), que encontram nesta formação social a busca pela sua felicidade pessoal, ganha especial relevo o elemento afetivo nas relações familiares. Assim não se pode mais relegar o vinculo conjugal ao segundo plano. 7(...) Por esta razão, o Código de 2002 alçou o cônjuge a herdeiro necessário em propriedade plena".

8 Ao discursar recentemente na Universidade de Coimbra, pela ocasião solene em que lhe era conferido o grau de doutor honoris causa, Caio Mário da Silva pereira deixou registradas as seguintes palavras: "A todos vós posso afirmar com irrefutável segurança que o Direito deve buscar, também em outras ciências, sobretudo, sociais e humanas, apoio e parceria para afirmar seus princípios, reorganizando, metodologicamente, estudos e pesquisas. As relações humanas não podem ser tratadas pelo Sistema Jurídico como se elas fossem apenas determinadas pelo mundo da objetividade. Outras ciências indicam novos rumos ao Direito". (Caio Mário da Silva Pereira. Discurso de Caio Mário na Universidade de Coimbra. Estado de Minas, $2^{a}$ ed., Belo Horizonte, 19 ago. 1999, p. 10. apud João Baptista Villela. ."O Modelo constitucional da filiação: verdade e supertições”. In: Revista Brasileira de Direito de Família, n. 2, Jul-Ago-Set/9, p.134)

${ }^{9}$ Neste sentido ressaltou Maria Celina Bodin de Moraes o erro profundo de perspectiva metodológica que vem sendo cometido por aqueles que entendem que as leis promulgadas posteriormente a Constituição de 88 , já foram interpretadas em consonância com os princípios por ela impostos. (Palestra proferida na Emerj em 20/05/2005 sobre o tema "Novos paradigmas do direito civil").

10 "Art. 1.601 Cabe ao marido o direito de contestar a paternidade dos filhos nascidos de sua mulher; 
buscando analisar os efeitos causados por esse dispositivo no estado de filiação, frente aos princípios norteadores das relações familiares impostos pela atual Constituição.

Embora antes de sua promulgação muito se tenha discutido, o legislador de 2002 optou, de forma diametralmente oposta ao Código Civil de 1916, por conferir imprescritibilidade à mencionada ação negatória. Esse entendimento já vinha gradativamente prevalecendo na jurisprudência, com o fim de garantir a busca da "verdade real". 11

Nessa perspectiva, parece essencial analisarmos as formas de estabelecimento da filiação, abordando os critérios jurídico, biológico e sócioafetivo, na constituição do vínculo paterno-filial.

De fato, é comum que estes critérios coexistam simultaneamente. No entanto, não raro ocorre o confronto entre eles, cabendo ao julgador avaliar, nesses casos, qual deles deve prevalecer diante da situação fática, priorizando o melhor interesse do filho ao qual a Constituição Federal conferiu proteção integral.

Com efeito, os avanços da biogenética, culminando com a descoberta do exame de DNA, viabilizaram o direito ao conhecimento da identidade genética

sendo tal ação imprescritível. Parágrafo único: Contestada a filiação, os herdeiros do impugnante têm direito de prosseguir na ação". Cumpre ressaltar que embora o Novo Código mencione sobre imprescritibilidade, o prazo anteriormente fixado era decadencial.

${ }^{11}$ No final da década de 90 o entendimento da Quarta Turma do Supremo Tribunal de Justiça já era da não aplicação do art. 178, $\S \S 3^{\circ}$ e $4^{\circ}$ do CC/1916. (RESP 146548 / GO, Rel. Min. César Afor Rocha, $4^{\mathrm{a}}$ Turma, Data do Julgamento: 29/08/2000 DJ 05.03.2001) No entanto, a Terceira Turma daquele Colendo Tribunal continuava entendendo que o prazo decadencial havia de ser aplicado, porém contados da data em que o marido tivesse tomado conhecimento dos fatos ensejadores da ação. (RESP 194866/RS - Rel: Min. Eduardo Ribeiro - Órgão Julgador: 3a Turma, Data do Julgamento: 20/04/1999, DJ 14.06.1999). (RESP 146548 / GO, Rel. Min. César Afor Rocha, 4 ${ }^{a}$ Turma, Data do Julgamento: 29/08/2000 DJ 05.03.2001). 
e, em muitos casos, a concretização do direito à paternidade, passando a ser o meio de prova mais utilizado nas ações que envolvem sua averiguação. ${ }^{12}$

Desse modo, com a possibilidade da determinação da paternidade através de um exame capaz de oferecer uma certeza científica plena de confiabilidade, o direito brasileiro passou a dar prioridade ao critério biológico da paternidade em detrimento do critério jurídico, que até então configurava o sistema clássico de estabelecimento da paternidade, fundado na presunção Pater is est ${ }^{13}$, nos termos do Código Civil de 1916. Assim, a "verdade" real da filiação para o direito passou a ser a "verdade" biológica.

Tão significativa a repercussão dessa descoberta que passaram os Tribunais a admitir a flexibilização da coisa julgada nas decisões que houvessem sido proferidas antes do advento do exame de DNA. Assim, passou-se a entender que nos casos em que as provas poderiam ser consideradas como "precárias", não haveria coisa julgada material, mas apenas formal, mitigando-se os efeitos da coisa julgada. ${ }^{14}$

\footnotetext{
${ }^{12}$ Assim relata Eduardo de Oliveira Leite ("O exame do DNA: reflexões sobre a prova científica da filiação". In: Repertório de doutrina sobre direito de família. São Paulo: Revista dos Tribunais, 1999, p. 191-192): "O surgimento do exame do DNA revolucionou o Direito e, sem dúvida, representa a contribuição mais espetacular conhecida neste meio desde a descoberta das impressões digitais e dos grupos sangüíneos. (...) A 'rainha das provas' suplantou todas as perícias hematológicas empregadas até então no debate judiciário civil e penal; o desenvolvimento da genética na última década abriu novos horizontes para a pesquisa científica, para as intervenções no campo biomédico e no campo das práticas jurídicas, que nos interessa mais particularmente".

13 "Pater is est quem nuptiae demonstrant", quer dizer: "É pai aquele que as núpcias legítimas indicam. Tal regra é de origem antiqüíssima, já constando no Digesto, fragmento de Paulo". (ZenoVeloso. Direito brasileiro da filiação e paternidade. São Paulo: Malheiros, 1997, p.52.)

14 "Não excluída expressamente a paternidade do investigando na primitiva ação de investigação de paternidade, diante da precariedade da prova e da ausência de indícios suficientes a caracterizar tanto a paternidade como a sua negativa, e considerando que, quando do ajuizamento da primeira ação, o exame pelo DNA ainda não era disponível e nem havia notoriedade a seu respeito, admite-se o ajuizamento de ação investigatória, ainda que tenha sido aforada uma anterior com sentença julgando improcedente o pedido". (REsp 226.436 - (1999/0071498-9) 4 4a turma - Rel. Min. Sálvio de Figueiredo Teixeira - J. 28.06.2001) No entanto, tal entendimento não é pacífico, conforme demonstra o posicionamento a seguir:"Ação de negativa de paternidade. Exame pelo DNA posterior ao processo de investigação de paternidade. Coisa julgada. 1. Seria terrificante para o exercício da jurisdição que fosse abandonada a regra absoluta da coisa julgada que confere ao processo judicial força para garantir a convivência social, dirimindo os conflitos existentes. Se, fora dos casos nos quais a própria lei retira
} 
Contudo, a problemática se instaura quando um pai registral, com base num resultado negativo do exame de DNA, propõe a demanda visando desconstituir o vínculo paterno-filial, já restando configurada, além da paternidade juridicamente estabelecida, a paternidade sócio-afetiva fundada na posse de estado de filho.

Nesse universo, essencial diferenciarmos o direito ao conhecimento da origem genética, que se insere nos direitos da personalidade, do direito à paternidade. Pois somente a partir desta distinção que seremos capazes de perceber a razão pela qual o advento do DNA não tem o condão de, por si só, constituir ou desconstituir um vínculo paterno-filial. ${ }^{15}$

A imprescritibilidade conferida à ação negatória de paternidade pelo Código Civil de 2002 gerou uma total insegurança jurídica para o filho, já que a qualquer tempo pode o marido da mãe contestar a paternidade, ignorando o legislador a realidade sócio-afetiva das relações familiares e, mais ainda, expondo o filho à eterna possibilidade de se deparar com a sua realidade e identidade completamente desfiguradas.

Atualmente, tanto a doutrina como a jurisprudência têm se posicionado, majoritariamente, a favor da imprescritibilidade conferida à ação negatória de

a força da coisa julgada, pudesse o magistrado abrir as comportas dos feitos já julgados para rever as decisões não haveria como vencer o caos social que se instalaria. A regra do art. 468 do Código de Processo Civil é libertadora. Ela assegura que o exercício da jurisdição completa-se com o ultimo julgado, que se torna inatingível, insuscetível de modificação. E a sabedoria do Código é revelada pelas amplas possibilidades recursais e, até mesmo, pela abertura da via rescisória naqueles casos precisos que estão elencados no art. 485. 2. Assim, a existência de um exame pelo DNA posterior ao feito já julgado, com decisão transitada em julgado, reconhecendo a paternidade, não tem o condão de reabrir a questão com uma declaratória para negar a paternidade, sendo certo que o julgado esta coberto pela certeza jurídica conferida pela coisa julgada. 3. Recurso especial conhecido e provido". (STJ, REsp. n. 1O7248/GO, 3 ${ }^{\mathrm{a}}$ Turma, Rel. Min. Carlos Alberto Menezes Direito, julg. 07.05.1998, in www.stj.gov.br).

${ }^{15}$ Esta diferenciação é feita por Paulo Luis Netto Lôbo ("O direito ao estado de filiação e o direito à origem genética: uma distinção necessária”. In: Revista Brasileira de Direito de Família, n. 19, Ago.Set./2003), como veremos mais tarde. 
paternidade, ainda que em sede doutrinária persistam muitas ponderações, principalmente no que tange ao não reconhecimento da paternidade sócioafetiva pelo ordenamento jurídico brasileiro. Além das diversas obras pesquisadas sobre a aplicação do dispositivo ora analisado (art.1601), registrase que a norma em comento é objeto de dois diferentes Projetos de Lei que visam a sua alteração. ${ }^{16}$

A prevalência do critério biológico no estabelecimento da filiação pelo direito brasileiro significa ignorar a dimensão que o conceito de paternidade engloba, pois tanto a realidade jurídica como a sócio-afetiva devem ser igualmente analisadas no estabelecimento do vínculo paterno-fílial. Por sua vez, o critério sócio-afetivo embora abordado pela doutrina e já presente em algumas decisões judiciais, ainda não se encontra positivado em nossa legislação.

Sob essa perspectiva, é primordial destacar que o tema se estrutura sob a ótica dos interesses do filho, diante da possibilidade de ter seu status desconstituído por outrem.

Para discutir o tema proposto, tomar-se-á como ponto de partida o processo de constitucionalização do direito civil através da positivação do

\footnotetext{
${ }^{16}$ O PL 4.946 de 2005 propõe a seguinte alteração: "Art. 1.601. Cabe exclusivamente ao marido o direito de impugnar a paternidade dos filhos nascidos de sua mulher. $\S 1^{\circ}$ Impugnada a filiação, os descendentes ou ascendentes do impugnante têm direito de prosseguir na ação. $\S 2^{\circ}$ Não se desconstituirá a paternidade caso fique caracterizada a posse do estado de filiação, ou a hipótese do inciso V do art. 1.597". (Disponível em www.ibdfam.com.br em 05/06/2005) Já o PL 6.960/2002 que encaminhou a seguinte proposta:"Art. 1.601. O direito de contestar a relação de filiação é imprescritível e cabe, privativamente, às seguintes pessoas: I - ao filho; II - àqueles declarados como pai e mãe no registro de nascimento; III - ao pai e à mãe biológicos. $\S 1^{\circ}$ Contestada a filiação, os herdeiros do impugnante têm direito de prosseguir na ação; $\S 2^{\circ}$ A relação de filiação oriunda de adoção não poderá ser contestada; $\S 3^{\circ} \mathrm{O}$ marido não pode contestar a filiação que resultou de inseminação artificial por ele consentida; também não pode contestar a filiação, salvo se provar erro, dolo ou coação, se declarou no registro que era seu o filho que teve a sua mulher; $\S 4^{\circ} \mathrm{A}$ recusa injustificada à realização das provas médico-legais acarreta a presunção da inexistência da relação de filiação".(Disponível em www2.camara.gov.br/proposições)
} 
princípio da dignidade da pessoa humana, como fundamento da República Brasileira, bem como sua propagação, atuando como princípio norteador que permeia todo o ordenamento jurídico. No primeiro capítulo também abordaremos o princípio do melhor interesse da criança e do adolescente, introduzido na legislação pátria pela ratificação da Convenção Internacional dos Direitos da Criança através do Decreto $n^{\circ}$ 99.710/90 e com fundamento constitucional, uma vez que decorre do próprio princípio da dignidade da pessoa humana.

Em seguida, faremos uma breve exposição dos critérios que fundamentam o vínculo paterno-filial, abordando as diferentes realidades jurídica, biológica e afetiva - sob as quais este vínculo pode se estabelecer. Nesse capítulo ainda analisaremos, com destaque, o conceito de posse de estado de filho sobre o qual se assenta a realidade sócio-afetiva.

Ao longo desse trabalho, pretendemos realizar uma ponderação entre a "busca da verdade real" e a realidade sócio-afetiva daqueles que já têm seu status de filho constituído, trazendo à colação algumas decisões judiciais no âmbito de nossos Tribunais.

Prosseguiremos a nossa investigação com o estudo sobre as ações de estado, visando diferenciar as ações afirmativas das negativas, para finalmente nos aprofundarmos na ação negatória de paternidade, objeto da presente monografia.

Em seqüência, buscaremos pontuar as diferenças entre as formas de contestação da paternidade, que podem se operar pela ação negatória da paternidade e/ou pela anulatória de registro, examinando, em cada uma delas, a 
legitimidade ativa, a matéria de prova cabível e os prazos para propositura da demanda.

Reservamos a conclusão para refletir sobre a compatibilização da imprescritibilidade das ações de estado negativas com os princípios constitucionais reguladores das relações familiares, quais sejam, a tutela de proteção da dignidade da pessoa humana e do melhor interesse do filho.

O presente estudo não tem, evidentemente, a pretensão de equacionar todas as questões que gravitam em torno da desconstituição do vínculo paterno-filial, objetivando, apenas a rigor, despertar a consciência da necessidade de reformulação das normas infraconstitucionais reguladoras das ações negativas de paternidade, buscando soluções capazes de tornar efetiva a proteção integral da criança e do adolescente com máxima prioridade, como prevê o texto constitucional. 


\section{Capítulo 1 - A Família fundada na dignidade humana e no melhor interesse dos filhos}

\subsection{A consagração da dignidade da pessoa humana como fundamento da República brasileira}

A Constituição de 1988 trouxe consigo os anseios por uma sociedade mais livre justa e solidária, desenhando um novo Estado Democrático de Direito fundado na proteção da dignidade da pessoa humana, como princípio fundamental positivado no art. $1^{\mathrm{o}}$, inciso III, da $\mathrm{CF} / 88$.

Esta busca pela proteção da dignidade humana iniciou-se com as críticas ao liberalismo e ao individualismo, no início do século XX e foi trazida à tona após a Segunda Guerra Mundial, em virtude da conscientização universal da fragilidade do ser humano. ${ }^{17}$

O "mundo da segurança", inaugurado pelo Código de Napoleão e cristalizado na pretensão de total completude que tinham os códigos modernos, cedeu lugar a uma "era de incertezas", que se por um lado gerou o enfraquecimento dos modelos tradicionais, por outro despertou uma nova consciência moral, uma nova ética. ${ }^{18}$

\footnotetext{
${ }^{17}$ Esta é a lição de Maria Celina Bodin de Moraes ("O princípio da solidariedade". In: Manoel Messias Peixinho et alii (org.), Os princípios da Constituição de 1988, Rio de Janeiro: Lumen Juris, 2001, p. 167): "Se o século XIX foi, reconhecidamente, o século do triunfo do individualismo, da explosão de confiança e orgulho na potência do indivíduo, em sua criatividade intelectual e em seu esforço particular, o século XX presenciou o início de um tipo completamente novo de relacionamento entre as pessoas, baseado na solidariedade social - conseqüência da reviravolta, na consciência coletiva e na cultura de alguns países europeus, decorrente das trágicas experiências vivenciadas ao longo da Segunda Grande Guerra".

${ }^{18}$ Neste sentido Maria Celina Bodin de Moraes ("Constituição e Direito Civil: Tendências", cit., p.99) destaca: "considera-se que a incerteza tenha acarretado um grande beneficio, beneficio este que, em perspectiva histórica, parece ter nascido no séc. XX, o século em que, pela primeira vez na história da humanidade, o desenvolvimento tecnológico alcançou tal nível que parece possível a completa
} 
Imprescindível destacar que a proteção da pessoa humana como centro da nova ordem constitucional refletiu a transformação do próprio conceito de indivíduo ao longo do tempo. A concepção individualista e voluntarista é abandonada frente à constatação, da própria sociedade, acerca da incapacidade de auto-suficiência do indivíduo como um ser fechado em si mesmo, gerando a consciência da necessidade de sua inserção social.

A concepção do indivíduo como um ser autônomo é substituída pela concepção do indivíduo como um ser social, solidário e responsável. A tutela da liberdade individual é abandonada pela noção de proteção à dignidade da pessoa humana. ${ }^{19}$ Constata-se que a consagração desse princípio como valor fundamental da sociedade contemporânea, vem acompanhada pela redescoberta da noção de solidariedade social.

Neste novo cenário é que se operou o reconhecimento da necessidade da aplicação das normas constitucionais nas relações privadas, resultando na perda da centralidade do Código Civil como "Constituição do direito privado" ${ }^{20}$, através do deslocamento do centro regulador do direito civil, para a Constituição Federal, como norma superior de todo o sistema normativo.

autodestruição da espécie humana e do planeta. O beneficio chama-se solidariedade. Este sentimento, o senso de igual dignidade para todas as pessoas humanas, é novo, não existia no passado. Ele decorre da conscientização de 'estarmos todos no mesmo barco'.".

${ }^{19}$ Maria Celina Bodin de Moraes. Danos à pessoa humana: uma leitura civil-constitucional dos danos morais. Rio de Janeiro: Renovar, 2003, p.72.

${ }^{20}$ Neste sentido constata Michele Giorgianni ("O Direito privado e as sua atuais fronteiras". In: Revista dos Tribunais, vol. 747, jan./ 1998, p. 49) "Que deste modo, o direito privado tenha perdido o caráter de tutela exclusiva do indivíduo para socializar-se, como se costuma dizer, não se poderia colocar em dúvida. Não se deveria duvidar, por outro lado, seja dito incidentalmente, que a atividade econômica privada já transcende as fronteiras das relações entre indivíduos, e penetrou no centro do corpo social...". 
Assim ressalta Ingo Wolfgang Sarlet "Com efeito, por sua natureza igualitária e por exprimir a idéia de solidariedade entre os membros da comunidade humana, o princípio da dignidade da pessoa humana vincula também no âmbito das relações entre os particulares". ${ }^{21}$

Neste sentido, oportuna a observação de Maria Celina Bodin de Moraes:

"É forçoso reconhecer que o Código Civil não mais se encontra no centro das relações de direito privado. Tal pólo foi deslocado, a partir da consciência da unidade do sistema e do respeito à hierarquia das fontes normativas, para a Constituição, base única dos princípios fundamentais do ordenamento jurídico". ${ }^{22}$

Essa aplicação da Constituição nas matérias civis mostrou-se essencial para a constitucionalização do direito civil, servindo também para comprovar a necessidade de superação da dicotomia direito público e direito privado, que por tanto tempo perdurou no Direito como duas esferas jurídicas totalmente distintas. $^{23}$

Não obstante, parece fundamental ressaltar que embora normas constitucionais passassem a disciplinar matérias civis, essas, de forma alguma, perderam sua natureza privada, o que confirma, justamente, a superação desta summa divisio.

\footnotetext{
${ }^{21}$ Dignidade da Pessoa Humana e Direitos Fundamentais na Constituição Federal de 1988, Porto Alegre: Livraria do Advogado, $2^{\mathrm{a}}$ ed. rev. e amp., p.112 e 113

${ }^{22}$ Maria Celina Bodin de Moraes. "A caminho de um Direito Constitucional" In: Direito, Estado e Sociedade - Revista do Departamento de Direito da PUC-Rio. Rio de Janeiro: n. 1, jul./dez., 1991, p.62

${ }^{23}$ É o que esclarece Maria Celina Bodin de Moraes ("Constituição e Direito Civil: Tendências", cit., p.101): "É preciso avaliar sistematicamente a mudança, ressaltando que se a normativa constitucional se encontra no ápice do ordenamento jurídico, os princípios nela presentes se tornaram, em conseqüência, as normas-diretivas, ou normas-princípio, para a reconstrução do sistema de direito privado. A nada serve, pois, continuar repisando, indefinidamente, que os conceitos jurídicos fundamentais de direito privado são aqueles contidos na sistemática codicística, quais sejam, a autonomia privada e seus desdobramentos, a propriedade e o contrato. É preciso, ao contrário, buscar perceber e valorar o significado profundo, marcadamente axiológico, da "constitucionalização' do direito civil".
} 
Assim, destaca também Gustavo Tepedino:

"O último preconceito a ser abandonado nessa tentativa de
reunificação do Direito Civil à luz da Constituição relaciona-
se à summa divisio do direito público e do direito privado. A
interpenetração do direito público e do direito privado
caracteriza a sociedade contemporânea, significando uma
alteração profunda nas relações entre o cidadão e o Estado". ${ }^{24}$

E conclui Pietro Perlingieri: "A Carta Constitucional representa o momento da realidade interna do ordenamento jurídico. Significa que não é mais possível distinguir o Direito Constitucional do Direito Civil, que não é mais possível se falar em Direito Público e Privado". ${ }^{25}$

Diante desse novo contexto houve a necessidade premente de se realizar uma releitura de todo o ordenamento jurídico a partir de uma ótica civilconstitucional, passando o sistema jurídico a ser visto como um sistema unitário, onde a Constituição Federal situa-se como norma suprema. ${ }^{26}$

Portanto, é à luz dos princípios constitucionais instaurados em nossa Carta Magna que se torna imperioso verificar, através de uma interpretação axiológica, quais normas devam ou não ser recepcionadas pela nova ordem constitucional. $^{27}$

\footnotetext{
${ }^{24}$ Gustavo Tepedino."Premissas metodológicas para a constitucionalização do direito civil”. In: Temas de Direito Civil. $3^{\mathrm{a}}$ ed, ver. e atual. Rio de Janeiro: Renovar, 2004, p. 19.

25 "Normas constitucionais nas relações privadas". In: Revista da Faculdade de Direito da UERJ. Rio de Janeiro: Universidade do Estado do Rio de Janeiro, n.6-7, 1998-1999, p.66

${ }^{26}$ Maria Celina Bodin de Moraes. "A caminho de um Direito Constitucional", cit., p.68.

27 Neste sentido ressalta Ingo Wolfgang Sarlet. Dignidade da Pessoa Humana e Direitos Fundamentais na Constituição Federal de 1988, Porto Alegre, Livraria do Advogado, $2^{\mathrm{a}}$ ed. rev. e amp., pp. 112 e 113.
} 
Na lição de Pietro Perlingieri: “A interpretação axiológica significa que o interesse da norma se faz levando em conta os princípios fundamentais de todo o sistema. Isto significa reler todo o ordenamento jurídico à luz da Constituição e dos valores fundamentais nos quais ela se baseia". ${ }^{28}$

Nesse novo cenário é que voltou a tramitar o Projeto do Novo Código Civil, hoje a Lei $n^{\circ} 10.406$ de 2002 já em vigor, devendo ser ressaltado que, ainda que nova, imprescindível que tal legislação se submeta a uma análise civil-constitucional para que sua aplicação se dê em plena conformidade com os preceitos constitucionais.

Somente sob esta nova ótica, determinada pelas escolhas éticofilosóficas e políticas da sociedade, é que o novo Código Civil deve ser lido e interpretado, à luz destes princípios contemplados em nossa Constituição, num contexto que não mais dá prioridade aos valores individualistas e patrimoniais, mas sim, como ressalta Maria Celina Bodin de Moraes ${ }^{29}$ :

\begin{abstract}
"trata-se, apenas e sempre, de buscar a primazia da dignidade da pessoa humana, consagrando-lhe plena e absoluta eficácia também no contexto que a ela mais diz respeito, na ordem jurídica que regula suas relações mais importantes, justamente porque são as relações que tocam mais de perto, isto é, o direito civil".
\end{abstract}

Tal princípio como valor supremo que se encontra no topo da ordem jurídica, se irradia por todas as demais normas do ordenamento e se coloca como principal critério para a ponderação de interesses. ${ }^{30}$ Assim assinala

\footnotetext{
${ }^{28}$ P. Perlingieri. "Normas constitucionais nas relações privadas", cit., p.66.

${ }^{29}$ Maria Celina Bodin de Moraes. "Constituição e Direito Civil: Tendências”, cit., p. 113.

${ }^{30}$ Neste sentido ressalta Daniel Sarmento (A ponderação de interesses na Constituição Federal. $1^{\mathrm{a}}$ ed., $3^{\text {a }}$ tiragem Rio de Janeiro: Lúmen Júris, 2003, p. 198): "O princípio da dignidade da pessoa humana desempenha múltiplas funções, entre as quais a de servir de critério material para a ponderação de interesses".
} 
Daniel Sarmento: "a dignidade da pessoa humana sendo um fim e não um meio para o ordenamento constitucional, não se sujeita a ponderações". ${ }^{31}$

Neste passo, destaca Ingo Wolfgang Sarlet: "impõe-se seja ressaltada a função instrumental integradora e hermenêutica do princípio, na medida em que este serve de parâmetro para aplicação, interpretação e integração não apenas dos direitos fundamentais e das demais normas constitucionais, mas de todo o ordenamento jurídico. ${ }^{32}$

Contudo, a amplitude do conceito de dignidade e o seu alto grau de abstração nos levam à grande dificuldade de conferir efetividade à aplicação deste princípio. É o que pondera Maria Celina Bodin de Moraes, recorrendo à filosofia para demonstrar a necessidade de se extrair o substrato material da dignidade a partir da concepção Kantiana, que destaca a dignidade como um atributo das pessoas enquanto o preço é atributo das coisas, norteando o conceito de dignidade como valor intrínseco às pessoas humanas. Assim, desdobra a autora esse substrato em quatro sub-princípios em relação ao princípio maior da dignidade da pessoa humana: o da igualdade, da integridade psicofísica, da liberdade e da solidariedade. Desse modo, ainda que em algumas situações exista um conflito entre estes sub-princípios de mesma hierarquia, através da ponderação entre eles, virá à tona, no caso concreto, qual deles deva prevalecer em favor do outro, para se garantir a proteção ao princípio maior da dignidade da pessoa humana. ${ }^{33}$

\footnotetext{
${ }^{31}$ Ver Daniel Sarmento, (cit., p.198) sobre a técnica da ponderação de interesses sobre a qual discorre sua obra. Nesse sentido também destaca Ingo Wolfgang Sarlet (cit., p.131) citando F. Ferreira dos Santos, (Principio Constitucional da Dignidade da Pessoa Humana, p. 94-96) que "a dignidade, na condição de valor maior do ordenamento jurídico, atua como principal critério substantivo na ponderação de interesses constitucionais, mas não poderá jamais ser objeto de ponderação, no sentido de se admitir sua violação ou relativização em face de outros valores constitucionais".

${ }^{32}$ Ingo Wolfgang Sarlet, cit., p. 85.

33 Assim demonstra a autora que: "O substrato material da dignidade assim entendida se desdobra em quatro postulados: i) o sujeito moral (ético) reconhece a existência dos outros como sujeitos iguais a ele, ii) m_recedores do mesmo respeito à integridade psicofísica de que é titular; iii) é dotado de
} 
Esta é a lição da autora ${ }^{34}$ :

"Quando nos chamados casos difíceis se impõe à necessidade de ponderar os interesses conflitantes quer-se com isso dizer ser cabível examinar, em cada hipótese, a qual princípio deva ser dado prioridade no caso concreto: à liberdade ou à solidariedade? À integridade psicofísica ou à liberdade? À igualdade ou à solidariedade? Os casos difíceis, no dizer Paul Ricouer, constituem um desafio à provação do julgamento reflexivo. O objetivo a ser alcançado, contudo, é único e não admite relativizações". (...) E conclui: "No Direito, hoje, tudo se tornou relativo, ou ponderável, mas em relação ao único valor capaz de dar harmonia, equilíbrio e proporção ao ordenamento jurídico: o princípio da dignidade da pessoa humana".

Constata-se que cada vez mais, a doutrina vem conferindo maior densidade a este princípio, com repercussões na jurisprudência que hoje já utiliza o princípio da dignidade da pessoa humana como critério balizador nas situações conflituosas, ${ }^{35}$ não deixando mais qualquer dúvida acerca da normatividade deste princípio, como conclui Ingo Wolfgang Sarlet:

vontade livre, de autodeterminação; iv) é parte do grupo social, em relação ao qual tem a garantia de não vir a ser marginalizado. São corolários desta elaboração os princípios jurídicos da igualdade, da integridade física e moral - psicofísica -, da liberdade e da solidariedade. Esta decomposição serve, ainda, a demonstrar que, embora possa haver conflitos entre duas ou mais situações jurídicas subjetivas, cada uma delas amparada por um desses princípios, e, portanto, conflito entre princípios de igual importância hierárquica, o fiel da balança, a medida de ponderação, o objetivo a ser alcançado, já está determinado, a priori, em favor do princípio, hoje absoluto, da dignidade humana. Somente os corolários, ou subprincípios em relação ao maior deles, podem ser relativizados; ponderados, estimados. A dignidade, assim como ocorre com a justiça, vem à tona no caso concreto, se bem feita aquela ponderação". (Dano à pessoa humana. Uma leitura civil-constitucional do dano moral. Rio de Janeiro: Renovar, 2004, p. 85)

${ }^{34}$ Maria Celina Bodin de Moraes. "Danos morais e relações de família. In: Anais do IV Congresso Brasileiro de Direito de Família. Afeto, Ética, Família e o Novo Código Civil (Coord.) Rodrigo da Cunha Pereira. Belo Horizonte: Del Rey, 2004, p. 408.

${ }^{35}$ Neste sentido, confira-se, Gustavo Tepedino ("A tutela da personalidade no ordenamento civilconstitucional brasileiro". In: Temas de direito civil, cit., p. 50): "Com efeito, a escolha da dignidade da pessoa humana como fundamento da República, associada ao objetivo fundamental de erradicação da pobreza e da marginalização, e de redução das desigualdades sociais, juntamente com a previsão do $\S 2^{\circ}$ do art. $5^{\circ}$, no sentido da não exclusão de quaisquer direitos e garantias, mesmo que não expressos, desde que decorrentes dos princípios adotados pelo texto maior, configuram uma verdadeira cláusula 
"A qualificação da dignidade da pessoa humana como princípio fundamental traduz a certeza de que o artigo $1^{\circ}$, inciso III, de nossa Lei Fundamental não contém apenas (embora também e acima de tudo) uma declaração de conteúdo ético e moral, mas que constitui norma jurídicopositiva dotada, em sua plenitude, de status constitucional formal e material e, como tal, inequivocamente carregado de eficácia." ${ }^{36}$

\subsection{O princípio do melhor interesse da criança e do adolescente como desdobramento do princípio da dignidade humana}

Como já visto, o art. 227 da Constituição Federal de 1988 conferiu proteção integral à criança e ao adolescente com absoluta prioridade, justamente por serem pessoas humanas em desenvolvimento, dispondo que é dever da família assegurar, ao lado do Estado e da sociedade, seus direitos fundamentais dentre os quais se destaca o direito à dignidade.

Tais disposições insculpem o princípio do melhor interesse da criança e do adolescente também incorporado em nossa legislação pela ratificação da Convenção Internacional dos Direitos da Criança aprovada em Assembléia Geral da ONU em 20 de novembro de 1989, através do Decreto 99.710/90, que em seu art. $3^{\circ}$ dispõe: “Todas as ações relativas às crianças, levadas a efeito por instituições públicas ou privadas de bem-estar social, Tribunais, autoridades administrativas ou órgãos legislativos, devem considerar, primordialmente, o interesse maior da criança". 37

\footnotetext{
geral de tutela e promoção da pessoa humana, tomada como valor máximo pelo ordenamento."

${ }^{36}$ Ingo Wolfgang Sarlet, cit., p.74.

${ }^{37}$ Tânia da Silva Pereira, destaca o texto original em inglês ("O Principio do Melhor Interesse da Criança: Da Teoria a Pratica”. In: Anais do II Congresso Brasileiro de Direito de Família. A Família na Travessia do Milênio.(coord.) Rodrigo da Cunha Pereira, Belo Horizonte, 1999, Del Rey, p. 215):: "all actions concerning children whether undertaken by public or private social welfare institutions,
} 
A proteção integral conferida com absoluta prioridade a criança e ao adolescente, destina-se à defesa de determinado grupo que necessita de um tratamento diferenciado, no caso, como justifica e legitima o próprio texto constitucional, essa proteção especial é conferida ao menor, justamente por esse se tratar de pessoa humana em desenvolvimento.

Esse é o sentido da igualdade substancial presente na Constituição de 88, que autoriza a adoção de discriminações positivas, através da incidência de normas específicas destinadas a determinados grupos de pessoas, visando efetivar uma igualdade real no caso concreto. Assim também ocorre no Estatuto da Criança e do Adolescente, no Código de Defesa do Consumidor e no Estatuto do Idoso.

Contatou-se que a igualdade formal que estabelecia que "Todos são iguais perante a lei", embora representasse um grande avanço conquistado pelo liberalismo, não era mais suficiente para garantir a proteção da dignidade da pessoa humana, na medida que não permitia um tratamento diferenciado àquilo que era diverso, o que é inconcebível numa sociedade solidarista e plural, justamente por ter como uma de suas características o respeito à existência das minorias. ${ }^{38}$

courtsof law, administrative authorities or legislative bodies, the best interests ofthe child shall be a primary consideration".

${ }^{38}$ Como assinala Maria Celina Bodin de Moraes (Danos à pessoa humana..., cit., p.93): "Como visto, o abandono da perspectiva individualista, nos termos em que era garantida pelo Código Civil, e sua substituição pelo princípio da solidariedade social, previsto constitucionalmente, produziram uma significativa transformação no âmago da própria lógica do Direito Civil - que se faz notar nas mais recônditas minudências do sistema. Com efeito, o legislador codicista estava voltado para garantir a igualdade de todos perante a lei - igualdade esta que, apesar de não ultrapassar o caráter formal, representava, à época, significativo avanço social. Essa posição, no entanto, era incompatível com o reconhecimento de quaisquer aspectos, particulares ou específicos, relativos aos destinatários das normas. Por seu turno, o legislador constituinte, apoiado nos princípios da dignidade humana e da solidariedade social, teve a pretensão de enfrentar as desigualdades concretas do contexto da sociedade brasileira contemporânea, ao propugnar,como objetivo fundamental da República - artigo $3^{\circ}$, III - a erradicação da pobreza e da marginalização social”. 
O princípio da igualdade, um dos corolários da dignidade humana, hoje aponta para além da igualdade substancial, para o direito à diferença. Nesse sentido ressalta Maria Celina Bodin de Moraes: "Torna-se, pois, necessário interpretar e aplicar o Direito a partir do respeito pela diferença, que deve sobressair, possibilitando a coexistência pacífica das diversas concepções de vida, cientes do que as distingue e do que as une - no caso, a singularidade de cada uma e a igual dignidade de todas as pessoas humanas". ${ }^{39}$

Este é também o sentido do princípio do melhor interesse da criança, quando impõe, no art. $3^{\circ}$ da Convenção acima citada, que em todas as ações que envolvam a criança o seu maior interesse é o que deve ser primordialmente considerado.

Assim, cumpre destacar que se é tarefa do legislador observar a diversidade existente entre os vários grupos, buscando mecanismos legais capazes de permitir a formação de um processo justo, com efetiva igualdade de condições entre as partes, também não pode o Judiciário se esquivar do dever de assegurar aplicação ao postulado da dignidade humana desde a propositura da demanda.

Quanto à normatividade deste princípio informado pela cláusula geral da tutela da pessoa humana, como observa Gustavo Tepedino, dispôs o art. $6^{\circ}$ do Estatuto da Criança e do Adolescente (Lei $\mathrm{n}^{0}$ 8.069/90) o seu critério

\footnotetext{
${ }^{39}$ Danos à pessoa humana..., cit., p.92. Neste sentido destaca José Ribas Filho (A Construção de um novo paradigma constitucional Rio de Janeiro: Renovar, no prelo.): "que a formulação clássica do princípio da igualdade impunha não só um tratamento igual daquilo que é substancialmente igual, quanto um tratamento desigual àquilo que é substancialmente desigual. Independentemente da existência de diversas diferenças nas condições de vida da sociedade, que não podem ser percebidas como uma situação deficitária, mas podem ser superadas para realização da igualdade deve, no entanto, valorar positivamente a diversidade, quando a ela se fizer uma exigência particular, que seja capaz de realizar e que as pessoas envolvidas nesta diversidade devem ser capazes de formar um grupo apto a produzir uma identidade entre seus integrantes".
} 
hermenêutico, impondo que "na interpretação desta lei, levar-se-ão em conta os fins sociais a que ela se dirige, as exigências do bem comum, os direitos e deveres individuais e coletivos, e a condição peculiar da criança e do adolescente como pessoas em desenvolvimento". Assim, assegura o Autor que o princípio "The best interest of the child" foi colhido por nossa mais sensível jurisprudência, adquirindo, entre nós, conteúdo normativo específico. ${ }^{40}$

O ECA, "expressão infraconstitucional do art. $227, \mathrm{CF}^{4}{ }^{41}$, reuniu toda matéria referente a esta proteção, através do desdobramento dos princípios constitucionais, reforçando o reconhecimento da criança como sujeito de direitos.

Em seu art. 27, como já assinalado, o referido diploma legal dispôs que "o reconhecimento do estado de filiação é direito personalíssimo, indisponível e imprescritível, podendo ser exercitado contra os pais e seus herdeiros sem qualquer restrição", garantindo ao filho, irrestritamente, investigar sua paternidade.

Juntamente com o princípio da isonomia, instaurado pelo texto constitucional, esse Estatuto buscou conferir uma maior efetividade ao direito à paternidade calcado num ideal de igualdade que procura concretizar este direito a todos os filhos, independente da origem da filiação.

Assim destaca Maria Cláudia Crespo Brauner ${ }^{42}$ :

\footnotetext{
40 "A disciplina civil-constitucional das relações familiares", cit., p. 450.

${ }^{41}$ Esta expressão é de Gustavo Tepedino ("A disciplina civil-constitucional das relações familiares", cit., p. 449).

42 "Considerações sobre a filiação extramatrimonial em Direito de Família francês e brasileiro". In: Revista da Faculdade de Direito, n. 27, Curitiba, 1992/93, p. 66.
} 
"Na concepção moderna, o filho extramatrimonial não é mais excluído e indiscriminado porque ele adquiriu um 'status' similar ao do filho legítimo. As noções de legitimidade e de ilegitimidade perderam seu conteúdo e sua justificação. $\mathrm{O}$ Direito deve garantir uma proteção integral à criança, seja ela oriunda de uma família matrimonializada ou não. Trata-se do reconhecimento da criança como sujeito de direitos".

Em seguida, a Lei $n^{0}$ 8.560/92, veio regular a investigação da paternidade dos filhos havidos fora do casamento, a averigüação oficiosa e o reconhecimento voluntário, criando mecanismos para facilitar a constituição do vínculo paterno-filial, impedindo que qualquer obstáculo inviabilizasse a averiguação da paternidade em sua plenitude, ao mesmo tempo em que também facilitou o reconhecimento voluntário da paternidade, ampliando as formas para esse reconhecimento. ${ }^{43}$

Neste cenário, o princípio do melhor interesse da criança ganhou uma grande abrangência, ${ }^{44}$ tornando-se imperiosa sua aplicação como uma cláusula geral em todos os casos que envolvam o interesse da criança e do adolescente. $^{45}$

\footnotetext{
${ }^{43}$ A Lei $\mathrm{n}^{\circ} 8560 / 92$, preceitua, em seu artigo $1^{\circ}$, que, além do registro de nascimento, da escritura pública e do testamento, o escrito particular e a manifestação expressa e direta perante o juiz como formas de reconhecimento de filiação. Já o artigo $2^{\circ}$ trata da averiguação oficiosa dispondo: "Em registro de nascimento de menor apenas com a maternidade estabelecida, o oficial remeterá ao juiz certidão integral do registro e o nome e prenome, profissão, identidade e residência do suposto pai, a fim de ser averiguada oficiosamente a procedência da alegação".

${ }^{44}$ Assim ressalta Tânia Da Silva Pereira (Tânia da Silva Pereira. Direito da criança e do adolescente, 1997, p. 639.) "O mundo jurídico assiste, neste século, fundamental mudança de paradigmas no que concerne à proteção da infanto-adolescência. Destinatária de inúmeros documentos internacionais de proteção de Direitos Humanos, a população infanto-juvenil passa a representar destacada preocupação das autoridades públicas dos diversos países, que vêem nela a continuação de seus projetos como Nação."

${ }^{45}$ Conforme ressalta Heloisa Helena Barbosa ("O Estatuto da Criança e do Adolescente e a disciplina da filiação no código civil". In: Tânia da Silva Pereira (coord.) O melhor interesse da criança: um debate interdisciplinar. Rio de Janeiro: Renovar, 2000, p.112): "Razoável, por conseguinte, afirmar-se que a doutrina da proteção integral, de maior abrangência, não só ratificou o princípio do melhor interesse da criança como critério hemenêutico, como também lhe conferiu natureza constitucional, como cláusula genérica que em parte se traduz através de direitos fundamentais da criança e do adolescente expressos no texto da Constituição Federal".
} 
Neste sentido conclui Luiz Edson Fachin ${ }^{46}$ :

"Deduz-se, pois, que as disposições cuja aplicação contrariem os princípios consignados na Constituição tornaram-se, então, inconstitucionais. Ademais disso, sabe-se que os princípios constitucionais do Direito de Família têm eficácia jurídica direta e são, portanto, normas vinculativas e, que, igualmente, os preceitos relativos ao Direito de Família devem ser interpretados e integrados em conformidade com estes princípios (princípios de interpretação conforme a Constituição)".

Todavia, o Código Civil de 2002, em matéria de filiação, se resumiu a repetir as novidades já trazidas pelo texto constitucional, deixando para trás a oportunidade de reconhecer diversas inovações formuladas pela doutrina e jurisprudência desenvolvidas, especialmente no tocante aos critérios estabelecedores do vínculo paterno-filial, como à paternidade fundada na realidade sócio-afetiva.

\subsection{0 novo paradigma do conceito de família e o instituto da} filiação

A Constituição Federal de 1988 refletiu as transformações da realidade social familiar brasileira, desde a sociedade patriarcal e hierarquizada até a sociedade contemporânea, pluralista, fundada na solidariedade familiar ${ }^{47}$, que passa a reconhecer novas formas de entidades familiares diversas do

\footnotetext{
${ }^{46}$ Averiguação e investigação da paternidade extramatrimonial: comentários à Lei $n^{\circ}$ 8.560/92. Curitiba: Genesis, 1995, p. 11.

${ }^{47}$ Assim ressalta Ana Luiza Maia Nevares (A tutela sucessória do cônjuge e do companheiro na legalidade constitucional. Rio de Janeiro: Renovar, 2004, p.77 ): "Na família, o dever de solidariedade realiza-se em diversos momentos da convivência familiar. Assim é a obrigação alimentar recíproca entre os membros da família, garantindo-se condições mínimas de subsistência do ser humano. Da mesma maneira, as relações entre pais e filhos traduzem a solidariedade objetiva, na medida em que o poder familiar está inserido na categoria do poder jurídico, encerrando uma situação subjetiva que confere a uma pessoa direitos e deveres, que devem ser exercidos no interesse de outra. De fato, o poder familiar é atribuído aos pais para que seja exercido em benefício e no interesse dos filhos menores, pessoas em desenvolvimento e, por esta razão, dotadas de especial proteção do Estado".
} 
matrimônio, como a união estável e as famílias monoparentais ${ }^{48}$, a igualdade entre os cônjuges e o princípio da isonomia entre os filhos.

Um longo período de dogmas e preconceitos que mantinham a família fundada no casamento a qualquer custo, ainda que em prejuízo de seus membros e principalmente de seus filhos, começa a dar lugar a uma família construída sobre os laços de afeto.

Como destaca Maria Cristina Crespo Brauner" ${ }^{49}$ "Compreender a evolução do Direito de família deve ter como premissa a construção e a aplicação de uma nova cultura jurídica, que nos conduz a conhecer a proposta de proteção às entidades familiais, estabelecendo um processo de repersonalização destas relações e, devendo centrar-se na manutenção do afeto, sua maior preocupação".

A busca por um ideal de justiça e igualdade substancial nas relações familiares, se configurou na transformação da família institucional em família instrumento, ultrapassando-se, finalmente, o conceito de família moldado sob uma ótica paternalista e hierárquica.

Sob essa ótica, mais autêntica, verdadeira e adequada às novas realidades sociais, é que a família passa a ser considerada como fundamento da sociedade, como ressalta Maria Celina Bodin de Moraes:

\footnotetext{
48 “Art. 226, parágrafo 3”, da CF/88: Para efeito da proteção do Estado, é reconhecida a união estável entre o homem e a mulher como entidade familiar, devendo a lei facilitar sua conversão em casamento". "Art. 226, parágrafo $4^{\circ}$, da CF/88: Entende-se, também, como entidade familiar à comunidade formada por qualquer dos pais e filhos".

49 "O pluralismo no direito de família brasileiro: realidade social e reinvenção da família". In: Direitos fundamentais do direito de família (coord.) Belmiro Pedro Welter e Rolf Madaleno. Porto Alegre: ed. Livraria do Advogado, 2004, p.255.
} 


\begin{abstract}
"A instituição familiar recebe a proteção legal se e enquanto mantém seu caráter de instrumento para o pleno desenvolvimento de aspectos existenciais, que dizem respeito à personalidade de seus membros, em detrimento das relações de dependência econômica, hoje não mais prioritariamente tuteladas". ${ }^{50}$
\end{abstract}

Nesse sentido também assinala Gustavo Tepedino:

\begin{abstract}
“A família, embora tenha ampliado, com a Carta de 1988, o seu prestígio constitucional, deixa de ter valor intrínseco, como instituição capaz de merecer tutela jurídica pelo simples fato de existir, passando a ser valorada de maneira instrumental, tutelada na medida em que - e somente na exata medida em que - se constitua em um núcleo intermediário de desenvolvimento da personalidade dos filhos e de promoção de seus integrantes". ${ }^{51}$
\end{abstract}

Portanto, conclui-se que é esta nova família que passa a ser desenhada pelo texto constitucional, onde prevalecem os laços de afeto, a solidariedade familiar e o direito a paternidade conferida a todos os filhos ${ }^{52}$, desvinculando a tutela dos filhos com a espécie de relação mantida pelos seus pais. Enfim, priorizando-se a parentalidade frente a conjugalidade.

Não obstante essa nova realidade social, o direito positivo brasileiro continua não reconhecendo a paternidade sócio-afetiva fundada na posse de estado de filho, utilizando este critério apenas subsidiariamente, ignorando, muitas vezes o que deveria ser prioritariamente protegido: o melhor interesse do menor.

\footnotetext{
${ }^{50}$ Maria Celina Bodin de Moraes. "A caminho de um direito civil-constitucional”, cit., pp. 70/71.

${ }^{51}$ Gustavo Tepedino. "A disciplina civil-constitucional das relações familiares”, cit ., p. 398.

${ }^{52}$ Claude Lévi-Strauss apud Elisabeth Roudinesco. (A família em desordem (trad.) André Telles. Rio de Janeiro: Jorge Zahar, 2003, p.15) já assinalava que: "o que diferencia realmente o homem do animal é que, na humanidade, uma família não seria capaz de existir sem sociedade, isto é, sem uma pluralidade de famílias prontas a reconhecer que existem outros laços afora os da consagüinidade, e que o processo natural da filiação somente pode prosseguir através do processo natural da aliança".
} 
Não devemos esquecer, como ressalta Elisabeth Roudinesco: $:^{53}$ "A família é reivindicada como um valor seguro, ao qual ninguém quer renunciar. Ela é amada, sonhada e desejada por homens, mulheres e crianças, de todas as orientações sexuais e de todas as condições".

É neste sentido que o presente trabalho se orienta, e, por isso, pareceu fundamental abordarmos, neste primeiro capítulo, os princípios regedores de nosso ordenamento jurídico e do instituto da filiação, para que não corramos o risco de perdê-los de vista em nosso estudo. Ao mesmo tempo, é essencial destacar que somente estes princípios serão capazes de nos fornecer subsídios para que, nos casos difíceis, saibamos ponderá-los, preservando sempre o princípio maior da dignidade da pessoa humana.

Em seqüência, no capítulo seguinte, iremos analisar os três critérios que determinam o estabelecimento do vínculo paterno-filial, bem como as situações onde há conflito entre eles. Assim, abordaremos o critério fundado na realidade jurídica, biológica e afetiva. Em referência a esta última, iremos aprofundar o conceito da posse de estado de filho que emerge justamente desta nova realidade social em que a família se encontra inserida, num contexto que valoriza o afeto, como o elemento unificador dos laços familiares. Com efeito, essa nova realidade nos impõe a "reinvenção da família". ${ }^{54}$

\footnotetext{
${ }^{53}$.A família em desordem, cit., p. 198.

${ }^{54} \mathrm{O}$ termo é utilizado por Maria Cláudia Crespo Brauner in "O pluralismo no direito de família brasileiro: realidade social e reinvenção da família", cit., p. 277.
} 


\section{Capítulo 2 - Os critérios de estabelecimento da filiação: as realidades jurídica, biológica e afetiva}

Até bem pouco tempo atrás somente a paternidade era passível de questionamentos. Mãe era indubitavelmente aquela que deu à luz ao seu filho. No entanto, com as técnicas de reprodução assistida, tornou-se plenamente possível que aquela que carrega o filho em seu ventre não seja a mãe biológica daquele embrião.

De qualquer forma, a paternidade continua sendo o principal alvo de contestação. Até porque, além da descoberta do exame de DNA que substituiu a prevalência do critério jurídico pelo critério biológico, os bancos de sêmen e as inseminações artificiais homólogas e heterólogas ${ }^{55}$ se tornaram parte da realidade contemporânea.

Por outro lado, não devemos esquecer que a realidade biológica é apenas um dos critérios de estabelecimento da filiação. $O$ vínculo que une os pais aos seus filhos vai muito além dos laços de sangue, o que não significa dizer que não seja um direito fundamental da pessoa humana ter conhecimento a sua origem genética, direito este que é garantido pela Constituição a todos os filhos. $^{56}$

\footnotetext{
${ }^{55}$ A reprodução artificial homóloga é aquela realizada com material genético do próprio casal, já a heteróloga, ocorre mediante o uso de material genético de um doador, estranho ao casal.

${ }^{56}$ Neste sentido expõe Maria Claudia Crespo Brauner ("Novos contornos do direito da filiação: a dimensão afetiva das relações parentais". In: Revista da AJURIS, n.78, jun/2000, p. 203): "Considerando-se que a busca da paternidade é uma exigência para a defesa dos interesses da criança, seguindo-se o modelo do sistema unificado da filiação adotado pela Constituição Federal de 1988 e, posteriormente fortalecido no Estatuto da Criança e do Adolescente (Lei $\mathrm{n}^{\circ}$ 8.069/90), pode-se perceber que toda a pessoa, menor ou maior, tem o direito de ter a filiação identificada e formalizada, considerando-se que o estabelecimento da filiação passa a ser uma necessidade e a paternidade um direito de toda a criança, adolescente ou adulto, sendo, portanto, um direito personalíssimo, indisponível e imprescritível, como preceitua o artigo 27 do referido Estatuto da Criança e do Adolescente."
} 
Portanto, torna-se fundamental a análise desses critérios que determinam o estabelecimento do vínculo paterno-filial, e principalmente das situações em que há conflito entre eles.

Como já assinalado, é certo que com o advento do exame de DNA, o critério biológico passou a prevalecer sobre o jurídico; contudo, é importante ressaltar que esse, ainda que de forma mais flexibilizada, continua presente em nosso ordenamento jurídico, nos incisos I a V do art. 1597 do Código Civil de 2002. Paralelamente, embora não positivado, coexiste o critério sócio-afetivo fundado na posse de estado de filho, que hoje já é abordado em sede jurisprudencial e principalmente doutrinária, devido à relevância que cada vez mais vem sendo conferida aos laços de afeto dentro das relações familiares. ${ }^{57}$

Neste sentido ressalta Pietro Perlingieri:

“o sangue e os afetos são razões autônomas de justificação para o momento constitutivo da família, mas o perfil consensual e a affectio constante e espontânea exercem cada vez mais o papel de denominador comum de qualquer núcleo familiar. O merecimento de tutela da família não diz respeito exclusivamente às relações de sangue, mas, sobretudo, àquelas afetivas que se traduzem em uma comunhão de vida". 58

\footnotetext{
${ }^{57}$ Como ressalta Maria Claudia Crespo Brauner, ("Novos contornos...”, cit., pp.203 e 204): “A família sociológica é a família onde predominam os laços de afeto e solidariedade entre pais e filhos e esta situação passa a ter, enfim, para o mundo jurídico, uma significação. Mesmo que de forma lenta, esta noção vem a ser concebida, num primeiro momento, um pouco intuitivamente para, num segundo momento, reivindicar-se uma posição clara da doutrina e da jurisprudência sobre o seu papel no sistema de estabelecimento da filiação".

${ }^{58}$ Perfis do direito civil..., cit., p. 244.
} 


\subsection{0 critério jurídico}

A família do início do século XX era patriarcal, hierarquizada e exclusivamente fundada no matrimônio, refletindo a moral imposta pela sociedade daquela época. Neste contexto é que foi promulgado o Código Civil de 1916, como destacou Gustavo Tepedino 59 : “A regulamentação legal da família voltava-se, anteriormente para a máxima proteção da paz doméstica, considerando-se a família fundada no casamento como um bem em si mesmo, enaltecida como instituição essencial".

No que se refere à filiação, o ordenamento jurídico só reconhecia os filhos oriundos do matrimônio, os quais eram denominados de "legítimos". A legitimidade era uma qualidade atribuída ao filho concebido na constância do casamento. Portanto, o vínculo que unia um filho ao seu pai era o jurídico, ou seja, aquele estabelecido pela lei, conforme dispunha o art. 337 do Código Civil de 1916, estabelecendo que ficando a maternidade configurada, pai era presumidamente o marido da mãe. Assim, qualquer incerteza acerca da paternidade era eliminada por força da lei, que prescrevia como legítimos, os filhos nascidos na constância do casamento de seus pais.

A desigualdade entre os filhos estava estampada na legislação, que somente permitia o reconhecimento da paternidade extramatrimonial em casos realmente excepcionais, pois o sistema jurídico tinha como principal objetivo à preservação da "paz" familiar. ${ }^{60}$

\footnotetext{
59 “A disciplina civil-constitucional das relações familiares". In: Vicente Barreto (org.). A nova família: problemas e perspectivas. Rio de Janeiro: Renovar, 1997, p. 56.

${ }^{60}$ Neste sentido destaca Luiz Edson Fachin (Estabelecimento da filiação e paternidade presumida. Porto Alegre: Sérgio Fabris, 1992, p. 45): "a idéia central que norteia o sistema é a da preservação da família calcada no matrimônio, pelo que se procura explicar a admissão do reconhecimento de filho ilegítimo excepcionalmente, apenas quando há manifestamente uma base para poder se estabelecer à verdade".
} 
Os limites para invalidar a presunção pater is est eram taxativos só autorizando, privativamente, ao marido da mãe, o direito de contestar à paternidade e através de ação específica e dentro de prazos decadenciais estabelecidos pela lei, conforme determinava o art. 178, parágrafo $3^{\circ}$, do Código de 1916. Somente em duas hipóteses era permitida tal contestação: no caso de não ter havido coabitação dentro do período legal da concepção, podendo esta ser provada pela separação legal dos cônjuges, ou pela impossibilidade física de coabitação à época da concepção e no caso da impotência absoluta e permanente para gerar filhos. Importante também destacar que tampouco a prova do adultério da mulher ou mesmo sua confissão eram suficientes para afastar a presunção de paternidade.

No caso da mãe que não era casada, a paternidade só poderia ser estabelecida nos casos de reconhecimento voluntário ou judicial da filiação.

Nesse cenário, os filhos oriundos nestas circunstâncias, eram denominados "ilegítimos", pois nascidos de pais não unidos pelos laços do matrimônio. Dentre estes, distinguia-se ainda os filhos em naturais, cujos pais não tinham impedimento matrimonial quando da sua concepção, dos filhos espúrios, quando seus genitores possuíam impedimentos absolutos para casar entre si. Dentre estes últimos, os filhos ainda poderiam ser denominados de incestuosos, quando advindos de parentes em grau proibido para o matrimônio ou adulterinos, quando nascidos de homem ou mulher casados com pessoa diversa da do cônjuge. ${ }^{61}$ Cumpre ainda ressaltar que somente era admitido o reconhecimento dos filhos naturais.

\footnotetext{
${ }^{61}$ Zeno Veloso, (cit., p. 12). O autor ainda comenta (cit., p. 23) que "A proibição de investigar a paternidade adulterina ou incestuosa, conforme o aludido art. 363, estava na lógica do sistema, sendo corolário da vedação do reconhecimento voluntário dos filhos dessas classes, como determinava o art. 358 ".
} 
Certo é que as mudanças, ainda que de forma lenta, foram ocorrendo na legislação, surgindo leis esparsas que revogaram artigos do Código de 1916, adequando-se, gradativamente, às transformações da sociedade.

Esse processo iniciou-se com o Decreto-Lei $\mathrm{n}^{0} 3200$, de 1941, que proibiu fazer constar nas certidões de registro civil a circunstância da filiação "ilegítima", aparecendo como uma primeira forma de proteção à filiação extramatrimonial. Em seguida, o Decreto-Lei $n^{0}$ 4737/42 possibilitou o reconhecimento voluntário dos filhos "ilegítimos", bem como a demanda judicial para tal fim, embora somente após o desquite. Posteriormente, a Lei $\mathrm{n}^{\mathrm{o}}$ 883/49 revogou o Decreto-Lei $n^{0} 4737 / 42$, permitindo ao cônjuge, tendo dissolvido o matrimônio, de qualquer forma, reconhecer filho seu havido fora do casamento, bem como conferiu ao filho o direito de propor ação própria para que fosse declarada a sua filiação. Esta lei também incluiu como herdeiro necessário o filho "ilegítimo", conferindo a este o direito de receber metade da herança que coubesse ao filho "legítimo" ou "legitimado". Além disso, permitiu o reconhecimento da paternidade da filiação "ilegítima" somente para fins de prestação de alimentos. Mais à frente, a Lei $n^{0}$ 6515/77, denominada “Lei do Divórcio", acrescentou um parágrafo único ao artigo 4, da Lei 883/49, que dispunha: "Dissolvida à sociedade conjugal do que foi condenado a prestar alimentos, quem os obteve não precisa propor ação de investigação para ser reconhecido, cabendo, porém, aos interessados, o direito de impugnar a filiação." Em seu artigo 51, a Lei n 6515/77 dispôs que "Qualquer que seja a natureza da filiação, o direito à herança será reconhecido em igualdade de condições", igualando em relação à herança paterna, fillhos "legítimos" e “ilegítimos”. Finalmente, esta lei considerada revolucionária à sua época, permitiu o reconhecimento do filho havido de relação fora do casamento ainda na constância da sociedade conjugal, desde que fosse através de testamento 
cerrado. Em 1984, a Lei no 7250 introduziu outra alteração na Lei no 883/49, prevendo a possibilidade do pai adulterino que estivesse separado de fato há mais de cinco anos de seu cônjuge, reconhecesse seu filho, fruto de uma relação extramatrimonial.

Desta maneira, destaca-se que o modelo clássico de estabelecimento da filiação difícultava o acesso à criação do vínculo paterno-filial, pois restringia o direito de investigar a filiação, criando uma hierarquia entre os filhos, de cunho nitidamente discriminatório com o objetivo de manter a estrutura de proteção aos interesses patrimoniais dos pais irresponsáveis que negligenciavam suas obrigações para com os filhos gerados de relações extraconjugais. $^{62}$

Conclui-se que a realidade da filiação era apenas a jurídica, ignorando-se a realidade biológica se esta configurasse uma ameaça à instituição familiar, evitando-se a revelação das relações adulterinas, ainda que em prejuízo dos filhos oriundos destas relações.

Atualmente, a presunção de paternidade estabelecida no art. 1597 do CC/2002, difere da prevista no CC/1916, ganhando novos contornos, não visando mais presumir a legitimidade do filho nascido na constância do casamento de seus pais, até porque a $\mathrm{CF} / 88$ vedou qualquer tratamento discriminatório entre os filhos. ${ }^{63}$ Portanto, tal presunção tem hoje apenas o condão de presumir ser o marido da mãe o pai dos filhos havidos por sua

\footnotetext{
${ }^{62}$ Maria Cláudia Crespo Brauner. "Novos contornos ...", cit., p. 199.

${ }^{63}$ Importante a distinção feita por Luis Edson Fachin (Estabelecimento da Filiação e da Paternidade Presumida, cit., p. 38): "Não raro identifica-se à presunção de paternidade com a presunção de legitimidade. É a que, por exemplo, pode induzir o art. 337 do Código Civil brasileiro. Essa confusão, porém, não tem mais razão de ser. Não se fala mais em presunção de legitimidade para se estabelecer uma presunção de paternidade do marido da mãe em relação aos filhos concebidos na vigência do matrimônio Tem sentido abandonar a menção à presunção de legitimidade quando o sistema imprime iguais direitos aos filhos havidos dentro e fora do casamento."
} 
mulher, uma vez que a coabitação e o dever de fidelidade são presunções da vida matrimonial. ${ }^{64}$

Percebe-se que a presunção Pater is est está bastante enfraquecida, aparecendo apenas como um reflexo do que normalmente ocorre no cotidiano das relações conjugais e por esse motivo dispensa a manifestação expressa do pai no registro do filho realizado pela mãe casada.

Como expõe Luiz Edson Fachin: “A função dessa presunção é a de permitir o estabelecimento da paternidade pelo simples fato do nascimento. $\mathrm{Ou}$ seja: quem nasce de uma mulher casada é filho do marido dessa mulher. Funciona, assim, tal presunção, como modo de estabelecimento da paternidade que opera automaticamente". 65

\subsection{0 critério biológico}

A certeza científica ${ }^{66}$ sobre a paternidade trazida pelo exame de DNA causou uma verdadeira revolução em relação à filiação, levando a uma confluência entre paternidade e origem genética passando a busca por essa origem a ser denominada de busca da "verdade real" sobre a paternidade.

De fato, o conhecimento à origem genética determinou um grande avanço para medicina facilitando o diagnóstico de doenças e correção de anomalias. ${ }^{67}$ Também em matéria de filiação, possibilitou a concretização do

\footnotetext{
${ }^{64}$ Rose Melo Vencelau, cit., p.137.

${ }^{65}$ Estabelecimento da filiação e paternidade presumida, cit., p. 35.

${ }^{66}$ Salmo Raskin. ("A análise de DNA na determinação de paternidade: mitos e verdades no limiar do século XXI”. In: LEITE, Eduardo Oliveira (coord.). Grandes temas da atualidade - DNA como meio de prova da filiação. Rio de Janeiro: Forense, 2000, p. 328): "No limiar do século XXI, não existe absolutamente nenhuma dúvida entre os cientistas quanto à extrema segurança e eficiência da análise de DNA para determinação da paternidade". Segundo o autor "Cabe, ainda esclarecer que o resultado de inclusão não chega a $100 \%$, não porque haja incerteza quanto ao resultado, mas por uma simples questão matemática decorrente da forma utilizada para o cálculo da probabilidade de paternidade calculada a partir do índice de paternidade (Teorema de Bays).

${ }^{67}$ Neste sentido destaca Alejandro Bugallo Alvarez. Principios informativos da relação de filiação: indagações à luz dos progressos da biotecnologia. "O direito à identidade biológica e ao conhecimento
} 
direito à paternidade responsável, conferindo uma maior efetividade a esse preceito constitucional.

Por outro lado, o deslumbramento com a certeza científica trazida pelo exame de DNA acerca da paternidade, que até então se cerceava num jogo de presunções, resumiu o vínculo paterno-filial ao vínculo biológico, parecendo ser este o único elo capaz de manter a união entre pais e filhos.

\title{
Assim ressalta Zeno Veloso:
}

\begin{abstract}
"Obviamente, até porque estão abarrotados de trabalho, muitos juízes receberam com extrema felicidade este notável progresso científico. Até a instrução probatória tradicional vem sendo substituída pela ordem, sem mais nada, de ser realizada a perícia genética. Assim, as outras provas parecem débeis, frágeis, desnecessárias, diante da prova absoluta, plena, vigorosa do DNA. O que estamos assistindo, nas questões de paternidade, é a sacralização, quando não a divinização da prova do DNA". ${ }^{68}$
\end{abstract}

Outro efeito do advento desse exame, já anteriormente exposto, foi o da mitigação da coisa julgada, entendendo os Tribunais que nas decisões que envolvessem o estado de filiação, processadas quando o exame ainda não era disponível e julgadas mediante provas precárias ou mesmo improcedentes por falta de provas, caberia a flexibilização da coisa julgada. ${ }^{69}$ Além disso, em

da mesma, não parece deva ser sacrificado em função de outros valores ou interesses, ao menos a partir da maioridade e, a qualquer momento, para fins de diagnóstico e correção de anomalias".

68 "A dessacralização do DNA" in Anais do II Congresso Brasileiro de Direito de Família. A família na travessia do milênio. Belo Horizonte: Del Rey, 2000, p. 197.

69"PROCESSO CIVIL. INVESTIGAÇÃO DE PATERNIDADE. REPETIÇÃO DE AÇÃO ANTERIORMENTE AJUIZADA, QUE TEVE SEU PEDIDO JULGADO IMPROCEDENTE POR FALTA DE PROVAS. COISA JULGADA. MITIGAÇÃO. DOUTRINA. PRECEDENTES. DIREITO DE FAMÍLIA. EVOLUÇÃO. RECURSO ACOLHIDO. I - Não excluída expressamente a paternidade do investigado na primitiva ação de investigação de paternidade, diante da precariedade da prova e da ausência de indícios suficientes a caracterizar tanto a paternidade como a sua negativa, e considerando que, quando do ajuizamento da primeira ação, o exame pelo DNA ainda não era disponível e nem havia notoriedade a seu respeito, admite-se o ajuizamento de ação investigatória, ainda que tenha sido aforada uma anterior com sentença julgando improcedente o pedido. II - Nos termos da orientação da Turma, "sempre recomendável à realização de perícia para investigação genética (HLA e DNA), porque permite ao julgador um juízo de fortíssima probabilidade, senão de certeza" na composição do conflito. Ademais, o progresso da ciência jurídica, em matéria de prova, está na substituição da 
alguns julgamentos, já em curso, passaram a ser convertidos em diligências, ${ }^{70}$ para a execução do exame considerado como prova imprescindível para a solução do processo.

Certo é que diante da repercussão atingida pelo DNA no direito de família brasileiro, diversas polêmicas começaram a surgir em sua volta, principalmente quanto a sua obrigatoriedade nas ações investigatórias de paternidade diante da recusa do suposto pai biológico a realizar o referido exame. Tal discussão chegou ao Supremo Tribunal Federal que decidiu em novembro de 1994, por maioria de votos (6 a 4), que ninguém poderia ser obrigado a submeter-se a exame pericial com a finalidade do estabelecimento da paternidade biológica. ${ }^{71}$

\footnotetext{
verdade ficta pela verdade real. III - A coisa julgada, em se tratando de ações de estado, como no caso de investigação de paternidade, deve ser interpretada modus in rebus. Nas palavras de respeitável e avançada doutrina, quando estudiosos hoje se aprofundam no reestudo do instituto, na busca, sobretudo, da realização do processo justo, "a coisa julgada existe como criação necessária à segurança prática das relações jurídicas e as dificuldades que se opõem à sua ruptura se explicam pela mesmíssima razão. Não se pode olvidar, todavia, que numa sociedade de homens livres, a Justiça tem de estar acima da segurança, porque sem Justiça não há liberdade". IV Este Tribunal tem buscado, em sua jurisprudência, firmar posições que atendam aos fins sociais do processo e às exigências do bem comum."(STJ, REsp. $n^{\circ}$ 226436/PR, 4a Turma, Rel. Min. Sálvio de Figueiredo Teixeira, julg. 28.06.2001, disponível em www.stj,gov.br).

70 "Investigação de paternidade cumulada com alimentos. Condenação lastreada em prova testemunhal e em perícia hematológica inconclusiva. Necessidade de busca da verdade real. Pretensão de realização de exame mais acurado do que ABO acolhida. Determinação da realização de DNA. Conversão do julgamento em diligência."(TJSC, Ap.Civ n. ${ }^{\circ}$ 99.011822-3, Rel. Des. Gaspar Rubik, julg. 30.08.2000, disponível em www.tj.sc.gov.br).

71 InVESTIGAÇÃo DE PATERnidAde - EXAME DNA - CONDUÇão DO RÉU "DEBAiXo DE VARA". Discrepa, a mais não poder, das garantias constitucionais implícitas e explícitas - preservação da dignidade humana, da intimidade, da intangibilidade do corpo humano, do império da lei e da inexecução específica da obrigação de fazer - provimento judicial que, em ação civil de investigação de paternidade, implique determinação no sentido de o réu ser conduzido ao laboratório, "debaixo de vara", para coleta do material indispensável à feitura do exame DNA. A recusa resolve-se no plano jurídico-instrumental, consideradas a dogmática, a doutrina e a jurisprudência, no que voltadas ao deslinde das questões ligadas à prova dos fatos. (STF - HC 71.373-4 RGS - Tribunal Pleno - Rel. p/ o acórdão: Min. Marco Aurélio - julg. 10.11.94, disponível em www.stf,gov.br). A respeito da presente decisão ver a profunda análise realizada pela Prof. Maria Celina Bodin de Moraes ("O Direito Personalíssimo à Filiação e a Recusa ao Exame de DNA: Uma Hipótese de Colisão de Direitos Fundamentais" in Revista Forense, vol.343, 1998”).
} 
Nesse rumo, passou então a se discutir se esta recusa não teria o condão de gerar a presunção relativa da paternidade. Sob esses aspectos, o art. 231 do novo Código estipula que a negativa do agente em submeter-se a exame médico necessário não poderá ser aproveitada em seu favor. Ainda, o art. 232 acrescenta que a recusa à perícia médica ordenada pelo juiz poderá suprir a prova que se pretendia obter com o exame. De fato, não chega a ser uma presunção, mas na esteira que já caminhavam alguns julgados, a negativa passou a poder servir como subsídio para que se entenda pela paternidade, como mais uma prova a seu favor. ${ }^{72}$ Em 2004, a questão foi então "pacificada" pelo Enunciado $n^{\circ} 301$ da Súmula do Supremo Tribunal de Justiça que dispôs que "em ação investigatória, a recusa do suposto pai a submeter-se ao exame de DNA induz presunção relativa (juris tantum) de paternidade".

Com a supervalorização do critério biológico, assumiu a doutrina um papel determinante para a reconstrução do instituto da filiação, assinalando para a importância do reconhecimento de uma realidade que estava à margem do direito brasileiro: a paternidade socioafetiva fundada na posse de estado de filho.

Não obstante, a importância do instituto passou a fomentar a doutrina causando repercussões na jurisprudência, principalmente nos casos em que se revela um conflito de paternidades. Assim, o grande foco de discussão deslocou-se para a ponderação da filiação biológica frente a socioafetiva.

\footnotetext{
72،“INVESTIGAÇÃO DE PATERNIDADE, EXAME DE DNA. PRESUNÇÃO DE PATERNIDADE. O ônus da prova é o meio para se atingir a escopo do processo, devendo, por isso, recair sobre a parte capaz de oferecer a melhor contribuição para o convencimento do juiz. A recusa do investigado em submeter-se ao exame, induz presunção que milita contra sua irresignação, e faz certo, do ponto de vista processual, o que já era provável. Sentença correta. Apelo improvido.”(TJRJ, Ap.Civ no 2001.001.16066, 93 Câmara Cível, ReI. Des. Laerson Mauro, julgo 04/12/2001, disponível em www.ti.rj.gov.br)
} 
Contudo a Constituição de 88 nos forneceu subsídios suficientes para os casos difíceis, pois ainda que não positivada a posse de estado de filho no ordenamento jurídico brasileiro, ao analisarmos a paternidade através de uma ótica civil-constitucional que se coaduna com o conceito de família delineado pelo texto constitucional, resta claro que esta não se funda somente na origem genética.

Ressalta-se mais uma vez que, apenas recentemente a paternidade socioafetiva ganhou lugar no cenário jurídico brasileiro, já sendo inclusive abordada pelos Tribunais. ${ }^{73}$

Nesse universo, pondera-se que "diante deste paradoxo de verdades, é preciso dizer que não deve haver prevalência ou predomínio de uma dimensão sobre a outra. A constituição jurídica da filiação pode ser fundada tanto na consangüinidade - já que ser filho é, antes de tudo, um dado biológico - quanto na socioafetividade - elo formado pelos laços afetivos, história pessoal de cada membro pautada por alegrias e tristezas, ligações de parentesco, apoio, comprometimento, solidariedade e influência do ambiente familiar e social, realidade esta que os testes científicos da descoberta da filiação não podem alcançar". 74

Ainda que o exame de DNA seja essencial nas ações que buscam o conhecimento da origem genética, da mesma forma esse não pode ser valorizado quando se trata de ações que visam desconstituir ou constituir o vínculo paterno-filial. Nessas, esse exame deve ser visto apenas como mais

\footnotetext{
${ }^{73}$ Neste sentido destaca Paulo Luiz Netto Lobo ("Direito ao estado de filiação e direito à origem genética: uma distinção necessária", cit., p.134 ): "Na tradição do direito de família brasileiro, o conflito entre a filiação biológica e a filiação socioafetiva sempre se resolveu em benefício da primeira. Em verdade, apenas recentemente a segunda passou a ser cogitada seriamente pelos juristas, como categoria própria, merecedora de construção adequada".

${ }^{74}$ Maria Christina de Almeida. "O paradoxo da Filiação Biológica e Sócio-afetiva". Artigo publicado no Boletim nº 22 do IBDFAM de Set./Out. de 2003.
} 
uma prova dentro do conjunto probatório a ser analisado, uma vez que não é apenas o vínculo biológico que deve nortear o estabelecimento da filiação. Assim já entendeu o Supremo Tribunal de Justiça, decidindo ser prescindível o exame de DNA em ação investigatória de paternidade. ${ }^{75}$

Torna-se, portanto, fundamental que no estabelecimento da filiação outros critérios sejam ponderados para que se constitua ou desconstitua o vínculo paterno-filial. Não basta a certeza da origem genética para transformar um genitor em pai. Ser pai também envolve um elemento volitivo, uma atitude externada de paternidade em relação ao filho, ainda que estabelecida por um dolo eventual, ou seja, quando o marido da mãe registra seu filho, assumindo o risco de não ter com o mesmo um vínculo biológico.

Nesse rumo, fundamental distinguirmos, como muito bem ressalta Paulo Luiz Netto Lôbo ${ }^{76}$ o direito ao estado de filiação do direito ao conhecimento à origem genética, uma vez que "o primeiro decorre da estabilidade dos laços afetivos construídos no cotidiano de pai e filho, constituindo o fundamento essencial da atribuição de paternidade ou maternidade". Assim ressalta o Autor que o estado de filiação "nada tem a ver com o direito de cada pessoa ao conhecimento de sua origem genética. São duas situações distintas, tendo a primeira natureza de direito de família e a segunda de direito da personalidade. As normas de regência e os efeitos jurídicos não se confundem nem se interpenetram".

\footnotetext{
75 "Investigação de paternidade. Exame DNA. Embora se trate de prova cuja produção é conveniente, não é impositivo seja realizada, se já existentes outros elementos que bastem à formação do convencimento do juiz. Hipótese em que a autora requereu sua produção e $o$ investigado absteve-se de a isso aquiescer, o que era indispensável, dada a natureza da prova. Não contraria a lei a decisão que, nas circunstâncias, negou requerimento, formulado já em segundo grau, visando a que se procedesse à diligência com aquele fim. Diplomata. Indenização de representação por exercício no exterior. Parcela que, dada sua natureza, não é de ser computada para o cálculo da pensão. Alimentos. Julgada procedente a investigação de paternidade, os alimentos são devidos desde a citação". (STJ, REsp. n. 248277/MG, 3a Turma, ReI. Min. Eduardo Ribeiro, julg.15/05/2005, disponível em www.stj.gov.br)

76 "O direito ao estado de filiação e o direito à origem genética: uma distinção necessária", cit.,, p.134.
} 
Cumpre inclusive destacar que o Supremo Tribunal de Justiça, em decisão ímpar também já abordou tal distinção em decisão que conferiu o direito do filho adotado de perquirir sua origem genética, mas entendendo que a adoção subsiste inalterada. ${ }^{77}$

Atualmente, podemos perceber que considerável parte da doutrina já entende que a realidade socioafetiva é a que deve ser priorizada no estabelecimento da filiação, como veremos no item a seguir. ${ }^{78}$

\subsection{0 critério afetivo e o conceito de posse de estado de filho}

As transformações ocorridas no direito de família após a Constituição de 88 abriram espaço para o ressurgimento da paternidade socioafetiva dentro do conceito atual de família desenhada pelo texto constitucional.

Conforme elucida Paulo Luiz Netto Lobo ${ }^{79}$ :

"O estado de filiação desligou-se da origem biológica e de seu consectário, a legitimidade, para assumir dimensão mais ampla que abranja aquela e qualquer outra origem. Em outras palavras, o estado de filiação é gênero do qual são espécies a filiação biológica e a filiação não biológica. Daí é de se

\footnotetext{
77، Adoção. Investigação de paternidade. Possibilidade. Admitir-se o reconhecimento do vínculo biológico de paternidade não envolve qualquer desconsideração ao disposto no artigo 48 da Lei 8.069/90. A adoção subsiste inalterada. A lei determina o desaparecimento dos vínculos jurídicos com pais e parentes, mas, evidentemente, persistem os naturais, daí a ressalva quanto aos impedimentos matrimoniais. Possibilidade de existir, ainda, respeitável necessidade psicológica de se conhecer os verdadeiros pais. Inexistência, em nosso direito, de norma proibitiva, prevalecendo o disposto no artigo 27 do ECA." (STJ, REsp n. 127.541/RS, 3 ${ }^{\text {a }}$ Turma, ReI. Min. Eduardo Ribeiro, julgo 10.04.2000, disponível em www.stj.gov.br)

${ }^{78}$ Rodrigo da Cunha Pereira. "Pai, por que me abandonaste?". In: O melhor interesse da criança e do adolescente: um debate interdisciplinar (coord.) Tânia da Siva Pereira. Rio de Janeiro, Renovar, 2000, p.580) destaca que "O Direito brasileiro já deveria ter entendido que por mais que se queira atribuir uma paternidade pela via do laço biológico, ele jamais conseguirá impor que o genitor se torne o pai. $\mathrm{O}$ alcance desta investigação limita-se na maioria das vezes, como já estabeleceu a lei francesa, para os fins de subsídios. Com isto, podemos entender que a Constituição brasileira de 1988, ao interferir no sistema de filiação, está a um passo do entendimento da paternidade em seu sentido mais profundo e real. Ela está acima dos laços sanguíneos. Um pai, mesmo biológico, se não adotar seu filho, jamais será o pai. Por isto podemos dizer que a verdadeira paternidade é adotiva e está ligada à função, escolha, enfim, ao Desejo".

79 "O direito ao estado de filiação e o direito à origem genética: uma distinção necessária", cit., pp.135 e 136.
} 
repelir o entendimento que toma corpo nos tribunais brasileiros de se confundir estado de filiação com origem biológica, em grande medida em virtude do fascínio enganador exercido pelos avanços científicos em torno do DNA".

É certo que os critérios jurídico e biológico, por si só, podem ser insuficientes para que se estabeleça a real paternidade. Ser pai porque a lei presumiu ou ser pai apenas pela descendência genética não revelam, necessariamente, a verdadeira paternidade. Ser pai implica num desejo, numa postura, que se constrói através da convivência diária baseada na afetividade que externa o desejo daquele que atua como pai, conferindo um sentido muito mais real e profundo ao elo paterno-filial.

Assim destaca Julie Cristine Delinsk ${ }^{80}$ que "a paternidade biológica, em determinados casos, coincide com a paternidade sócio-afetiva. Entretanto, confrontando-se as duas, esta pode preponderar sobre aquela, tendo em vista que revela muito mais do que laços de sangue, revelam laços de afeto entre pai e filho". E complementa Zeno Veloso ${ }^{81}$ : "Quem acolhe, protege, educa, orienta, repreende, veste, alimenta, quem ama e cria uma criança, é pai. Pai de fato, mas, sem dúvida, pai”.

Nesse contexto é que também ressurge o conceito de posse de estado de filho ${ }^{82}$, que segundo Paulo Luiz Netto Lobo, "constitui-se quando

\footnotetext{
${ }^{80}$ O novo direito da filiação. São Paulo: Dialética, 1997, p. 81.

${ }^{81}$ Direito brasileiro da filiação e da paternidade, cit., p. 215.

${ }^{82}$ Maria Claudia Crespo Brauner ("Novos contornos...", cit., pp. 205 e 206) destaca que "a idéia de posse de estado de filho não é recente, ao contrário, ela é muito remota e já conhecida antes mesmo que os países civilizados organizassem o sistema de registro de nascimentos, que primeiramente, eram oficializados nas paróquias, sob a égide do Direito Canônico. Assim sendo, os elementos da realidade fática, ou seja, o tratamento de um adulto para com uma criança, os cuidados com o seu sustento e o afeto serviam para considerar a existência de um laço de filiação entre eles. Consistiria num reconhecimento espontâneo de filiação, não havia necessidade de documentos que comprovassem tal parentesco. Bem mais tarde, com as primeiras codificações, a partir de 1800 e a institucionalização do matrimônio, surgiu à discriminação dos filhos nascidos de relações não formalizadas sendo que, a incidência $d a$ presunção de paternidade legal desconsiderou o elemento fático da filiação,
} 
alguém assume o papel de filho em face daquele ou daqueles que assumem os papéis ou lugares de pai ou mãe ou de pais, tendo ou não entre si vínculos biológicos. A posse de estado é a exteriorização da convivência familiar e da afetividade, segundo as características adiante expostas, devendo ser contínua". 83

Não obstante a posse de estado de filho não estar contemplada em nossa legislação, podemos encontrar na própria jurisprudência decisões que já tem acolhido esse instituto, embora, na maioria das vezes, apenas como uma prova subsidiária.

Ademais, a doutrina tem realizado papel fundamental na demonstração da relevância desse instituto como único meio capaz de garantir o melhor interesse do filho, na medida que dele se emerge a verdadeira realidade da paternidade, possibilitando a solução dos conflitos no âmbito do direito de filiação, através da manutenção do elo paterno-filial que melhor proteja o desenvolvimento do filho, como prima nossa Constituição. ${ }^{84}$

Essa é a lição de Julie Cristine Delinski ${ }^{85}$ ressaltando a importância da posse de estado de filho:

"Com a busca da verdadeira paternidade percebe-se que a verdade da filiação não está fundada apenas na descendência genética, pois, para se estabelecer à verdadeira relação paterno-filial, há necessidade da presença de outros elementos; então surge aqui a valorização das relações

estabelecendo somente o critério legal para determinação da filiação. O reconhecimento de filho passou a ser um ato formal e a simples posse de estado de filho, pão servia para demonstrar a filiação e, muito menos, para criar o vínculo legal entre pai e filho". (Novos contornos..., cit., p.205 e 206)

83 "O direito ao estado de filiação e o direito à origem genética: uma distinção necessária", cit., p.138.

${ }^{84}$ Neste sentido, Luiz Felipe Brasil Santos, citando o Prof. José Bernardo Ramos Boeira ("A posse de estado de filho e a contestação da paternidade" artigo publicado no boletim do IBDFAM de Set/Out de 2003) afirma que "a verdade socioafetiva deve assumir papel de destaque, sobretudo nos casos em que é importante manter a estabilidade de famílias que cumpram o seu papel afetivo e social, embora não assentem num vínculo biológico, e ainda nos casos em que se deva evitar o reconhecimento da fíliação biológica por inconveniência para os interesses do filho".

${ }^{85}$ O Novo Direito da filiação, cit., p. 49. 
fundadas no afeto, buscando-se a paternidade sócio-afetiva. A valoração da"posse de estado" se efetiva para dar subsídios ao julgador a fim de reconhecer não a paternidade fundada apenas em presunção jurídica, ou na verdade biológica, mas sim aquela que retrata a relação paterno-filial fundamentada na relação de existência, sedimentada pela vida em comum."

Sob essa perspectiva que surge a importância de nos debruçarmos na análise desse conceito, uma vez demonstrado ser ele fundamental nas situações onde há conflito de paternidades.

O estado de filiação é obtido através da presunção da paternidade, do reconhecimento voluntário ou judicial e da adoção, ou seja, através dos meios jurídicos que a lei dispõe para sua constituição. Contudo, como destaca Perlingieri, "do título constitutivo do status distingue-se a posse de estado que é, segundo as hipóteses, elemento sanante dos defeitos de forma do título de estado e prova legal do fato do qual depende o nascimento do estado pessoal civil: assim, a filiação pode ser provada com a posse continuada deduzida de uma série de fatos". ${ }^{86}$

A doutrina clássica define que a posse de estado de filho se revela através de três elementos que a constituem: o nome, o trato e a fama. Todavia, ressalta Luiz Edson Fachin que "é sabido que estes são os principais dados formadores daquele conceito, mas nem a doutrina nem o legislador se arriscam em dar um rol completo ou definição acabada dos fatos aptos a constituí-lo". ${ }^{87}$

Conforme Julie Cristine Delinski ${ }^{88}$ "o primeiro elemento, a nominatio ou nomen é considerado como o uso constante do nome de família do pretendido pai, ou seja, àquele filho é atribuído o nome do pai. O tractautus é a situação resultante de ser o indivíduo criado, educado, tido e apresentado como filho

\footnotetext{
${ }^{86}$ Perfis..., cit., p. 137.

${ }^{87}$ Estabelecimento..., cit., p. 156.

${ }^{88}$ O Novo Direito da filiação, cit., p. 4.
} 
legítimo, pelo pai e pela mãe. E o terceiro elemento, a reputatio ou fama, que consiste na situação resultante de ser o filho sempre considerado na família e na sociedade como filho "legítimo" das pessoas de quem ele afirma ser".

Todavia, a própria doutrina vem dispensando, na análise do caso concreto, a necessidade de coexistência simultânea desses elementos. Como por exemplo, no caso de uma filiação adulterina, onde o pai não registra, mas torna-se presente, sustentando, visitando e tratando o filho como tal, resta a posse de estado de filho configurada. ${ }^{89}$

Além disso, a doutrina é unânime quanto à necessidade de ser conjugado a esses elementos, o fator tempo. Não que haja a determinação de um período certo, mas é necessário um período suficiente para provar a consistência do estabelecimento dessa posse de estado de filiação. ${ }^{90}$

Diante dessas considerações, percebe-se a importância e a relevância da posse de estado de filho no estabelecimento da filiação e, conseqüentemente, a imprescindibilidade de seu reconhecimento pelo ordenamento jurídico

\footnotetext{
${ }^{89}$ Neste sentido destaca Julie Cristine Delinski (Novo Direito da filiação, cit., p.44 e 45) que "os outros dois elementos (tractatus e fama) são capazes de demonstrar a "posse de estado", revelando assim a paternidade sócio-afetiva, pois, constituindo-se esse instituto em verdadeiro estado de permanente e reiterado comportamento dos pais em relação ao filho, nada melhor do que buscar a sua caracterização através do tratamento que é despendido pelo suposto pai em relação ao filho. São esses elementos que fornecem a densidade suficiente para o reconhecimento da "posse de estado". Importa lembrar que não se podem estabelecer conceitos apriorísticos do trato e da fama. É necessário estudar cada caso emparticular. A determinação deles decorre das circunstâncias que rodeiam as situações fáticas. Até mesmo a posição social e o grau de educação das pessoas envolvidas são fatores que se devem considerar para a configuração e tipificação desses dois elementos essenciais. Depreende-se do texto que a conjugação dos três elementos para a caracterização da "posse de estado de filho" não é taxativa".

${ }^{90}$ Ainda em relação aos elementos da posse de estado de filho, Julie Cristine Delinski ( $O$ Novo Direito da filiação,cit., p.48) pondera: "De forma que, além dos elementos constitutivos da "posse de estado", exige-se certa continuidade, ou seja, uma permanência no tempo para que esses elementos clássicos venham a ser considerados consistentes. A existência da "posse de estado de filho" supõe "habitualidade" e "estabilidade" relativas, o que não significa que deva ser "perpétua". A "continuidade" supõe uma duração suficiente. Nos termos da noção de "posse de estado de fillho", não há como desvinculá-la do elemento "tempo", pois, como já mencionado, não se resume num fato pontual; ela vem dia após dia, ela se constrói, ela se intensifica com o passar do tempo".
} 
brasileiro.

Fundamental, nesse contexto, também tem sido o papel do Instituto Brasileiro de Direito de Família (IBDFAM) na luta pela valorização da ética e do afeto como os dois valores que devem nortear as relações familiares.

$\mathrm{Na}$ abertura dos Anais do IV Congresso Brasileiro de Direito de Família Maria Berenice Dias ressaltou mais uma vez que "não ter lei não quer dizer não ter direitos, e é de todo descabido invocar a ausência de lei como justificativa para negar a jurisdição". E complementa: “É indispensável reconhecer que o afeto é uma realidade digna de tutela, e para isso é preciso levantar o véu do preconceito e arrancar a venda da injustiça”.

Sem dúvida, esse tem sido o papel da doutrina, preenchendo lacunas e conferindo densidade aos conceitos abertos, presentes na legislação.

Resta claro que os princípios fundamentais positivados na Constituição de 88 nos forneceram subsídios suficientes para afirmar que não há qualquer fundamento jurídico para tal desvio hermenêutico restritivo ao estabelecimento do vínculo paterno-filial, que abriga o estado de filiação de qualquer natureza, sem primazia de um sobre outro. Como ressalta Paulo Luiz Netto Lôbo": "Na realidade da vida, o estado de filiação de cada pessoa humana é único e de natureza socioafetiva, desenvolvido na convivência familiar, ainda que derive biologicamente dos pais, na maioria dos casos. Portanto, não pode haver conflito com outro que ainda não se constituiu”.

De fato o exame de DNA permitiu a concretização da paternidade responsável permitindo dar, ainda que apenas um pai biológico àquele que não

91 “O direito ao estado de filiação e o direito à origem genética: uma distinção necessária”, cit., pp.135 e 136. 
tinha e, sem dúvida, que para um filho, é melhor ter um pai, mesmo que não the dê afeto, mas que por sua paternidade e seu sustento se responsabiliza, do que não ter nenhum. Afinal, a obrigação de um pai em conferir amor ao seu filho, nenhuma legislação conseguirá impor ou suprir, por isso o que nos resta, como operadores do direito, é proteger ao máximo as relações onde naturalmente exista essa paternidade fundada no amor, na dedicação e no afeto.

Diante dessas considerações partiremos para análise do objeto central deste trabalho, abordando mais detalhadamente as formas de contestação da paternidade proposta por pessoa diversa do filho.

\section{Capítulo 3 - A contestação da paternidade}

Primeiramente, cabe lembrar que o enfoque deste trabalho incide na pessoa do filho, aquele que pelas formas de contestação da paternidade poderá ter seu status desconstituído. Porém, abordaremos somente as hipóteses em que a contestação da paternidade está sendo proposta por pessoa diversa do filho, para finalmente analisarmos mais profundamente a imprescritibilidade conferida à negatória de paternidade pelo Código Civil de 2002, principal objeto deste estudo.

De início, mister se faz localizarmos a negatória de paternidade dentro do rol das ações que envolvem o estado das pessoas, que podem ser afirmativas ou negativas; em seguida, é necessário diferenciaremos o fundamento desta das demais formas de contestação da paternidade, para então, finalmente analisarmos suas características particulares (legitimidade ativa, matéria de prova cabível e prazo para a propositura da demanda), alteradas pelo Código ora vigente. 


\title{
3.1 Das ações que versam sobre o estado da pessoa
}

A proteção da dignidade da pessoa humana envolve não somente a proteção da pessoa como indivíduo, mas também dentro dos grupos sociais dos quais faz parte. Assim, ressalta Perlingieri ${ }^{92}$ que os direitos invioláveis do homem devem ser garantidos:

\begin{abstract}
"quer como indivíduo, quer formações sociais onde se desenvolve a sua personalidade, não há razões para atribuir aos direitos que cabem ao indivíduo como membro da família, uma natureza diversa daquela que cabe ao indivíduo como pessoa. A indisponibilidade do status pessoal não deriva da natureza pública da família, mas do significado de ordem pública que assume o livre e pleno desenvolvimento da pessoa: essa circunstância não permite que tais estados sejam objeto de transações ou de compromissos arbitrais e requer, nas causas relacionadas com o estado, a intervenção do Ministério Público". (grifos nossos)
\end{abstract}

As ações que versam sobre o estado da pessoa podem ser afirmativas ou negativas. Denominam-se afirmativas as ações propostas pelo próprio indivíduo, que visa constituir, contestar ou alterar o seu próprio status. Já as negativas são aquelas propostas por legitimado que visa alterar ou modificar o status de outrem.

Sob essa perspectiva elucida Perlingieri" ${ }^{93}$ : "as ações de estado, que tendem em via principal a reclamar, contestar ou modificar os estados pessoais, de regra, são imprescritíveis quando a pessoa age para afirmar a veracidade do próprio status e são prescritíveis quando o legitimado age para contestar ou modificar o estado de outrem".

\footnotetext{
${ }^{92}$ Perfis..., cit., pp. 137 e 138.

${ }^{93}$ Perfis..., cit., p. 138.
} 
No entanto, no Superior Tribunal de Justiça já prevalece há algum tempo, o entendimento de que as ações de estado devem ser imprescritíveis, fundamentando muitas vezes este posicionamento pela interpretação dada ao art. 27 do Estatuto da Criança e Adolescente e pelo enunciado 149 da Súmula do STF, que determinam que a ação de investigação de paternidade é imprescritível e não admite restrições, sendo a busca pela paternidade um direito personalíssimo, indisponível e imprescritível do filho.

Diante das considerações acima expostas, este posicionamento deve ser melhor analisado, ponderando-se que a ação de investigação de paternidade é uma ação afirmativa, regulada pelo ECA que visa justamente à proteção da pessoa do filho, diferentemente da negatória de paternidade que permite justamente a desconstituição desse status por outrem.

Como já analisado, o resultado negativo de exame de DNA, provando a ausência de vínculo biológico entre o pai e o filho, tem sido o principal documento instrutório dessas demandas e potencialmente, tem possibilitado se afastar a paternidade. Aliás, na grande maioria das demandas, este exame tem sido utilizado como principal fundamento nas sentenças julgadas procedentes, que decidem pela desconstituição do vínculo-paterno-filial, principalmente no caso dos filhos presumidos pelo casamento de seus pais.

Em contrapartida, já encontramos decisões, que diante da análise de todo conjunto probatório, não consideram a ausência do vinculo biológico suficiente para desconstituir a paternidade, quando já configurada a posse de estado de filho. Num cenário, como demonstrado no capítulo anterior, que caminha para a valorização da paternidade sócio-afetiva em nome da preservação do melhor 
interesse do filho. ${ }^{94}$

\subsection{Das ações que viabilizam a contestação da paternidade}

Contextualizando, importante lembrar que, antes do advento da Constituição de 88 o status de filho englobava várias classificações. Com o princípio da isonomia instaurado pela nova ordem constitucional proibindo, definitivamente, qualquer distinção entre filhos independente de sua origem, configurou-se um único status em relação à filiação: o status de filho, ao qual deve ser conferido máxima proteção.

Esse status, como já dito anteriormente, pode ser obtido através de diferentes formas: mediante a presunção de paternidade, através do reconhecimento voluntário, forçado ou ainda pela adoção.

Já a desconstituição do estado de filiação pode se operar pela ação investigatória de paternidade, exclusiva do filho, pela negatória de paternidade ou pela ação de anulação de registro. Assim elucida Cáio Mário da Silva

\footnotetext{
94، Negatória de paternidade. Declaração falsa de filiação. Desconstituição do registro. Impossibilidade. Paternidade sócio-afetiva. Carência de ação. É carecedor de ação visando desconstituir o registro de nascimento. o pai que reconhece formalmente a filha, sendo sabedor da inexistência do liame biolóGico, mas deixando evidenciada a situação de paternidade sócio-afetiva. Vedação dos art. 104 do Código Civil e art. $1^{\circ}$ da Lei n. 8.560/92. Embargos Infringentes acolhidos".(grifos nossos) (Embargos Infringentes n ${ }^{\circ}$ 70001152933. Quarto Grupo de Câmaras Cíveis do Tribunal de Justiça do Rio Grande do Sul. Relator Desembargador Sérgio Fernando de Vasconcellos Chaves. Julgado em 11/08/00. Disponível em www.tj.rs.gov.br).

"Ação para Anular Registro de Nascimento. Legitimidade ativa. Verdade formal, verdade material e verdade sócio-Afetiva. Gratuidade judiciária e execução da sucumbência. O filho do de cujus tem legitimidade para anular registro de nascimento feito por seu pai, o qual entende falso. O de cujus teve muito tempo para renegar a sua paternidade. Tinha muitos meios de prova que não era pai. Contudo, preferiu viver como verdadeiro pai. Assumiu e se responsabilizou, sem ligar para o que a ciência genética poderia dizer. Um registro de nascimento deve atentar mais para a verdade sócioafetiva do que para a verdade biológica. A execução da sucumbência, havendo o benefício da gratuidade judiciária, deve ficar suspensa. Rejeitadas as preliminares, deram provimento ao apelo". (grifos nossos) (Apelação Cível n 70002016038, 88 Câmara Cível, Tribunal de Justiça do Rio Grande do Sul, Relator Desembargador Rui Portanova. Julgado em 08/03/2001. Disponível em www.tj.rs.gov.br)
} 


\section{Pereira $^{95}$ :}

"Para se desconstituir a relação de filiação, em princípio, podemos identificar dois tipos de ações, além da ação investigatória: a "negatória da paternidade" e a "ação de anulação do registro civil". Filiamo-nos à corrente que admite cumulação de pedidos devendo ser a ação julgada no Juízo de Família, em procedimento ordinário, fundado no art. $292 \mathrm{e}$ $\S \S$ do CPC. José Carlos Barbosa Moreira ${ }^{96}$ explica que "não é requisito de admissibilidade de cumulação haver no processo um Único réu, ou dirigirem-se os pedidos cumulados a um único réu, ou dirigirem-se os pedidos cumulados a um único dos co-réus: existindo litisconsórcio passivo, de acordo com as normas que regem o instituto, podem cumular-se pedidos contra os vários litisconsortes, ou contra parte deles, desde que atendidos os $\S \S 1^{\circ}$ e $2^{\circ}$ do art. 292".

A ação negatória de paternidade visa desconstituir a paternidade presumida dos filhos havidos na constância do casamento, com fundamento no art. 1601 do CC/2002, já a ação de anulação de registro somente pode ser manejada, provando-se erro ou falsidade deste, e tem seu fundamento nos arts. 1604 e 1608 do CC/2002 e 113 da Lei de Registros Públicos.

\section{Ainda neste âmbito de diferenciações, esclarece Caio Mário da Silva Pereira: ${ }^{97}$}

"Optamos por distinguir a ação negatória daquela que tem o objetivo de impugnar a paternidade. A primeira tem por objeto negar o status de filho ao que goza da presunção decorrente da concepção na constância do casamento. Esta última visa negar o fato da própria concepção, ou provar a sucessão de parto, e, por via de conseqüência, a condição de filho".

Não obstante tais distinções, a jurisprudência tem se utilizado da ação negatória para as diversas hipóteses de contestação de paternidade, seja para

\footnotetext{
${ }^{95}$ Caio Mário da Silva Pereira. Instituições de Direito Civil. V. 5 - Direito de Família. Rio de Janeiro: Forense, 2004, pp. 327 e 328.

${ }^{96}$ Barbosa Moreira apud Caio Mário da Silva Pereira (cit., p. 327) ressalta que "Também não é raro encontrarmos a ação investigatória de paternidade cumulada com pedido de anulação de registro, que também poderá levar a desconstituição do vínculo paterno-filial”.

${ }^{97}$ Instituições de Direito Civil, cit., p. 333.
} 
impugnar a paternidade presumida, seja para anular o registro por erro, falsidade ou ainda por outro vício de consentimento. ${ }^{98}$

O grande problema é que embora todas essas hipóteses visem à desconstituição do vínculo paterno-fililial, são disciplinadas de forma diversa, tanto no que se refere à legitimidade ativa, como em relação à matéria de prova cabível e aos prazos para propositura da demanda, o que torna ainda mais difícil a compreensão do emaranhado de normas que regulam a matéria.

Cumpre também destacar que, na hipótese de contestação visando à impugnação do registro, nos deparamos também com os casos de adoção à brasileira (adoção irregular), única hipótese, em que, na maioria das vezes, quando proposta pelo pai registral tem sido julgada improcedente, por ser equiparada ao reconhecimento voluntário, este irrevogável, como dispõe o arts. 1609 e 1610 do CC/2002, salvo se comprovado algum vício de consentimento,

\footnotetext{
98 Sobre esta distinção dispõe Rose Melo Vencelau, fazendo uma comparação com a negatória regulada pelo CC/1916, ponderando que atualmente tal confusão também se dá pelo fato do objeto das duas ações terem se tornado muito parecidos. (Op. cit., pp.171 e 172): “Assim, a ação de contestação da paternidade seria própria dos filhos havidos no casamento, visando negar a sua legitimidade. A ação de impugnação abarcaria um número maior de hipóteses, voltadas para a falsidade ou erro do registro. A primeira teria fundamento legal no art. 1.601 do Código Civil de 2002 (art. 344, CC1916). A segunda teria embasamento legal no art. 1.604 do Código Civil de 2002 (art. 348, CC1916). Quando vigorava a classificação entre filho legítimo e ilegítimo, fazia algum sentido a distinção, uma vez que a presunção era de legitimidade. In favores legitimitatis é que se cercava a ação negatória de legitimidade - não de paternidade como hoje usualmente se denomina - de todo tipo de restrição: de legitimidade ativa, de prova e de prazo. Atualmente, a presunção de paternidade beneficia o filho na medida em que se prescinde do reconhecimento formal da paternidade para que esta seja juridicamente estabelecida. Porém, quando o pai presumido nega a presunção está também negando a concepção, ou seja, a própria paternidade. Não é mais o status de filho legítimo que se nega, porque a Constituição veda esse tipo de qualificação. Desta forma, o objeto das duas ações se tornou muito parecido, se não é o mesmo, uma vez que ambas têm o fito de afastar a paternidade". (grifos nossos) A decisão a seguir demonstra exatamente tal "confusão", pois não é raro a jurispriudência chamar a anulatória de registro como negatória de paternidade: "Ação negatória de paternidade. Pai registral. O reconhecimento espontâneo da paternidade por quem sabe não ser o pai biológico tipifica verdadeira adoção (adoção à brasileira), a qual é irrevogável, descabendo postular-se anulação do registro de nascimento, salvo se demonstrada de forma convincente a existência de vício de consentimento, o que inocorreu". Em seu voto o relator destaca: "Conforme se encontra na melhor doutrina a respeito da matéria, a ação negatória de paternidade ou a anulatória do registro de nascimento, quando interpostas pelo pai registral, deve ter como fundamento vício de consentimento".APELAÇÃO DESPROVIDA. (TJRS APELAÇÃO CÍVEL N ${ }^{\circ}$ 70010231843- Oitava Câmara Cível Rel. Des. ALFREDO GUILHERME ENGLERT - Julgado em 16/12/2004 - Disponível em www.tj.rs.gov.br)
} 
ou à adoção regular, também irrevogável nos moldes do art. 48 da Lei $n^{\text {o }}$ 8.069/90. De fato, não é razoável que o pai registral, após efetuado o registro consciente de não haver vínculo biológico, venha alegar a falsidade desse registro que ele mesmo efetuou. ${ }^{99}$

Nessa esteira, ressalta João Baptista Villela que "Verdade e falsidade no registro civil e na biologia têm parâmetros diferentes. Um registro é sempre verdadeiro se estiver conciliado com o fato jurídico que lhe deu origem. (...) O cidadão que comparece espontaneamente a um cartório e registra, como seu filho, uma vida nova que veio ao mundo, não necessita qualquer comprovação genética para ter sua declaração admitida". ${ }^{100}$

Dessa forma, torna-se fundamental analisarmos cada uma das ações separadamente, para que possamos distinguir as suas peculiaridades, bem como os diversos argumentos utilizados pela jurisprudência, revelando uma realidade assustadora, na medida que coloca o filho em situações de total insegurança jurídica, em decorrência da imprescritibilidade admitida em lei.

\footnotetext{
${ }^{99}$ Neste sentido ver a jurisprudência comentada pelo Prof. Zeno Veloso (Revista Brasileira de Direito de Família, n. 3, Out-Nov-Dez/99, p.73) “A Segunda Câmara Cível do Tribunal de Justiça de Minas Gerais, julgando a Apelação Cível n 117.577/7, Comarca de Pouso Alegre, Relator Desembargador RUBENS XAVIER FERREIRA, à unanimidade de votos, deu provimento ao recurso. Do extenso e muito bem fundamentado voto do Relator, verifica-se que a declaração de M.E.A, no Registro Civil, do que C.E.A era sua filha, configurava uma "adoção à brasileira", não sendo lícito que o declarante, que agiu voluntária e conscientemente quando efetuou o registro, venha querer, posteriormente, anular o ato que praticou, alegando ter incorrido em erro substancial, porquanto não é o verdadeiro pai. Expôs o Relator que a declaração de vontade tendente ao reconhecimento voluntário da filiação é irretratável. A exemplo do que ocorre com os demais atos jurídicos, a invalidação pode verificar-se em razão de erro, dolo, coação, simulação ou fraude, observando-se, no caso, que foi o próprio apelado (M.E.A) que deu causa à realização do registro, e é de sabença geral que ninguém pode alegar em seu beneficio a própria torpeza. Pelas razões expostas no voto, e por outras, mais, estou de pleno acordo com a decisão referida". (grifos nossos) 100 "O modelo constitucional da filiação: verdade e superstições". In: Revista Brasileira de Direito de Família, n. 2, Jul-Ago-Set/99, pp. 139 e 140.
} 


\subsubsection{Da ação negatória de paternidade fundada no art. 1601 do CC/2002}

Como já assinalado, a ação negatória de paternidade tem como objetivo contestar à paternidade presumida dos filhos havidos na constância do casamento.

$\mathrm{O}$ art. 1597 do CC/2002, em seus incisos I ao V, trata das hipóteses que geram a presunção de paternidade dos filhos havidos na constância do casamento:

"I - nascidos cento e oitenta dias, pelo menos, depois de estabelecida a convivência conjugal; II - nascidos nos trezentos dias subseqüentes à dissolução da sociedade conjugal, por morte, separação judicial, nulidade e anulação do casamento;

III - havidos por fecundação artificial homóloga, mesmo que falecido o marido;

IV - havidos, a qualquer tempo, quando se tratar de embriões excedentários, decorrentes de concepção artificial homóloga;

V - havidos por inseminação artificial heteróloga, desde que tenha prévia autorização do marido".

Os incisos I e II traduzem mera repetição do art. 338 do Código Civil de 1916, embora já não tratassem de presunção de legitimidade, mas sim de paternidade. Os incisos III, IV e V tratam da presunção de paternidade dos filhos concebidos por técnicas de reprodução assistida.

A primeira controvérsia que se instaura é quanto à aplicabilidade da presunção de paternidade à união estável. Parte da doutrina já vem sustentando que a esta também se aplica à normativa. Caio Mário da Silva Pereira ressalta que "tais dispositivos devem ser revistos de imediato, uma vez que a união 
estável é hoje entidade familiar protegida pelo Estado e logo às presunções dispostas no art 1597 a ela também se aplicam”. ${ }^{101}$

Em sentido contrário, Paulo Luiz Netto Lôbo entende que especificamente neste caso não é admissível a interpretação extensiva da norma prevista neste artigo à união estável "não apenas pela estrita referência a marido e mulher, contendo-a ao âmbito do casamento, mas pela natureza da união estável que envolve a assunção da maternidade e da paternidade do filho como ato livre de cada companheiro". ${ }^{102}$

Certo é que a união estável é entidade familiar reconhecida pela $\mathrm{CF} / 88$, mas não pretendeu o legislador constituinte igualá-la ao casamento, até porque se correria o risco de tal entidade perder o próprio sentido de sua existência. Dessa maneira, se uma companheira for ao registro civil de pessoas naturais para registrar a criança, ela só vai registrar a criança e reconhecer a maternidade. No entanto, quando a mulher é casada, basta que ela apresente a certidão de casamento no ato registral para que esta também tenha a paternidade de seu filho reconhecida. A questão é controvertida, mas tudo indica que não quis o legislador estender tais hipóteses de presunção de paternidade à união estável. ${ }^{103}$

\footnotetext{
${ }^{101}$ Op. cit., p. 315.

${ }^{102}$ Código Civil comentado. Direito de família, relações de parentesco, direito patrimonial: Arts. 1.591 a 1.693, vol. XVI. (coord.) Álvaro Villaça Azevedo. São Paulo: Atlas, 2003, pp.78 e 79

${ }^{103}$ Neste sentido Lúcia Maria Teixeira (O Novo Código Civil do Direito de Família, (coord.) Heloísa Maria Daltro Leite, Rio de Janeiro: Freitas Bastos, 2002, pp. 184 e 185) pondera que "como no Código anterior, a presunção de paternidade se aplica apenas aos filhos concebidos na constância do casamento e não da união estável". Segundo a autora "o princípio da igualdade da filiação pode gerar divergências doutrinárias e jurisprudenciais, visto que muitas vozes respeitadas deverão sustentar que a presunção de paternidade deve ser aplicada também no âmbito da união estável, sendo esse um problema delicadíssimo, não se podendo discriminar os filhos em razão de sua origem".
} 
Muito pertinente é a observação de Luiz Edson Fachin, ressaltando que “como a Constituição manteve o casamento como fonte da família, desaparece a designação discriminatória, mas permanece a distinção. Há um resíduo diferenciador sem que implique uma ofensa ao princípio da igualdade, porque distinguir não significa discriminar".

Entre o Código de 1916 e a CF/88, como já demonstrado, a legislação infraconstitucional se encarregou gradativamente de alargar a possibilidade da declaração da filiação havida fora do casamento, ainda que permanecesse a distinção entre os filhos. Somente com o advento da Constituição de 1988, instaurando o princípio da isonomia, é que o direito à paternidade passou a ser estendido a todos os filhos havidos ou não da relação matrimonial.

O Código Civil de 2002, em seu art. 1601 não se referiu, como o Código de 1916 havia feito, à legitimidade privativa do marido, mas não a estendeu a qualquer outra pessoa.

Contudo, entende Caio Mário da Silva Pereira que "deixou de ser do marido "privativamente" (como estabelecera o art. 344 de 1916) o direito de contestar a paternidade do filho nascido de sua mulher ou companheira. Cabe, portanto, também ao companheiro, como ao próprio filho. Se o marido é incapaz torna-se admissível seja ação ajuizada pelo seu representante". E mais a frente complementa que quanto à legitimidade apenas pai presumido, poderia propor essa demanda:

\footnotetext{
"Considerando que, do art. 1.601, foi excluída a referência "privativamente" para designar a exclusividade do marido para contestar a paternidade do filho nascido de sua mulher não deve ser dele, apenas, a ação visando ilidir a presunção de paternidade, se o filho foi concebido fora dos prazos
} 
básicos da presunção estabelecida no art. 1.597. Reportandose à paternidade sócio-afetiva Paulo Luiz Netto Lobo, considera que o genitor biológico não tem ação contra o pai sócio-afetivo, marido da mãe, para impugnar a paternidade. Apenas o pai sócio-afetivo pode impugnar a paternidade quando a constatação da origem genética diferente da sua provocar a ruptura da relação paternidade-filiação. O mesmo autor ressalva, ainda, que a contestação da paternidade não pode ser decisão arbitrária do marido, quando declarou no registro que era seu o filho que teve com a mulher em virtude do princípio venire contra factum proprium nulli conceditur. A contestação, neste caso, terá de estar fundada em hipótese de invalidade dos atos jurídicos, que o direito acolhe, tais como erro, dolo, coação. Na dúvida deve prevalecer a relação de filiação sócio-afetiva, consolidada na convivência familiar, considerada prioridade absoluta em favor da criança". ${ }^{104}$

Quanto à legitimidade do pai biológico, não podemos esquecer que a ele cabe propor ação de anulação de registro por falsidade, com base no art. 1604 do $\mathrm{CC} / 2002$, a qual analisaremos a seguir. Esta se julgada procedente, irá desconstituir a paternidade jurídica presumida para afirmar a paternidade biológica. Neste caso trata-se de uma ação negativa e afirmativa ao mesmo tempo. De qualquer forma caberá ao juiz analisar qual era o vínculo que tinha o filho com o seu pai registral. Pois, configurada a paternidade sócio-afetiva fundada na posse de estado de filho, não é a ausência de vínculo biológico suficiente para desconstituir a paternidade já estabelecida sob os laços de afeto que unem o filho àquele pai registral, ainda que seja para transformar seu pai biológico em pai jurídico, uma vez que com este o filho pode não ter qualquer relação.

Contra a legitimidade do pai biológico também defende Sílvio Rodrigues ${ }^{105}$ que o filho pode investigar a paternidade em face de terceiros,

\footnotetext{
${ }^{104}$ Op. cit., p.321 e 330

${ }^{105}$ Silvio Rodrigues, Direito Civil: Direito de Família. $28^{\mathrm{a}}$ ed. rev. e atual. São Paulo: Saraiva, 2004, p. 304
} 
igualmente, o pai biológico, que teria mantido a relação adulterina com a mãe tem o direito de ver reconhecida à filiação em ação própria, porém, pondera o autor, que tanto em um como em outro caso, o resultado final poderá desconstituir a paternidade presumida, porém como efeito reflexo das ações próprias, não por meio da negatória que, segundo ele é privativa do pai presumido.

Outro ponto ainda polêmico refere-se à legitimidade do filho. Fato é que pertinentemente questiona a doutrina se não seria inconstitucional continuar não admitindo ao filho tal legitimidade, não só frente ao art. 27 do ECA, mas principalmente pelos princípios constitucionais da tutela da pessoa humana e do melhor interesse do filho. Neste sentido, destaca Gustavo Tepedino:

"Nesta esteira, o Código Civil de 2002 manteve apenas uma das restrições acima referidas, a que diz respeito à legitimidade processual que, segundo o art. 1.601, cabe ao marido. Contudo, a supressão do termo"privativamente" não deve ser vista sem propósito, pois seguindo a inteligência acima aduzida, não se pode deixar de afirmar que o filho tem hoje o direito à busca da paternidade." 106

No mesmo sentido salienta Rose Vencelau ressaltando, todavia, que tal legitimidade só deve ser estendida ao filho:

"Sob o prisma civil-constitucional o pai continua sendo legitimado ativo para a propositura da ação negatória de paternidade, mas não privativamente. $\mathrm{O}$ filho também possui legitimidade para contestar a paternidade do marido de sua mãe. Primeiramente, em função da unidade da filiação, ao filho presumido deve ser conferido o mesmo direito que tem o filho reconhecido voluntariamente de impugnar a paternidade do marido de sua mãe, ainda que haja o vínculo biológico. Em segundo lugar, em decorrência da livre investigação de paternidade que lhe é atribuída, quer seja pela legislação infraconstitucional (art. 27, Lei no 8.069/90),

106 “A disciplina jurídica da filiação na perspectiva civil-constitucional”, cit., p. 458. 
quer seja em face do princípio da unidade da filiação (art. $\left.227, \S 6^{\circ}, \mathrm{CF}\right)$, não podendo ser restringida sequer pela presunção pater is est. E também para impugnar o registro, por não ser o pai presumido o biológico". ${ }^{107}$

Em sentido contrário, defende parte da doutrina, na linha do Projeto de Lei $\mathrm{n}^{\circ}$ 6.690/2002 que este rol de legitimados deve ser ampliado. Segundo este Projeto, os legitimados ativos para contestar a relação de filiação deveriam ser: 1) o filho; 2) o pai e a mãe registrais; 3) o pai e a mãe biológicos; 4) quem demonstrar interesse legítimo. ${ }^{108}$

Certamente, alargar o rol de legitimados da ação negatória de paternidade é resumir mais uma vez a paternidade ao vínculo biológico, desconsiderando a paternidade sócio-afetiva e colocando em jogo um vínculo paterno-filial fundado nos laços de afeto que só ao pai e ao filho interessam. Contestar a paternidade presumida pelo casamento é completamente diferente de contestar a paternidade fundada no erro ou falsidade de registro, como veremos ao tratar da ação de anulação de registro.

Nesse ponto, acertadamente, optou o legislador de 2002 em não conferir à mãe ou a qualquer outra pessoa legitimidade para contestar a paternidade

\footnotetext{
${ }^{107}$ Op. cit., pp. 150 e 151. A autora também cita interessante ponderação sobre esse assunto realizada por Fernanda Otoni de Barros (Do direito ao pai, Belo Horizonte, Del Rey, 2000, pp. 74 e ss) demonstrando o quanto pode ser traumatizante para a criança ser submetida aos caprichos da mãe que, ora decreta ser um o pai, ora outro. É o que se verifica nesses dois casos tomados como exemplo: (Caso I - Paternidade e afeto) "A mãe entra com processo na justiça requerendo investigação da paternidade de uma filha que, até a data do processo, tinha como suposto pai o companheiro da mãe. $\mathrm{O}$ pai dito como verdadeiro, biológico, não tem nenhuma relação com a criança e não quer assumir a paternidade. O pai que a criança sempre conheceu e chama de pai, o qual nomearemos aqui por 'paisocial', não quer perder o lugar de pai desta criança, mesmo sabendo que este é filha adulterina. A pergunta do processo: quem é o pai?". (Caso 2 - O pai e o capricho materno) "O pai biológico entra com um processo na justiça requerendo regulamentação de visitas à sua filha. A mãe, depois da separação, proibiu suas visitas. Quando recebe o alvará para visitar a filha, descobre que esta foi adotada, em tempo recorde, pelo atual companheiro da mãe. A pergunta do processo: quem é o pai?"

${ }^{108}$ Neste sentido, também concordam Sílvio Venosa (Direito Civil: Direito de Família, 4a ed. São Paulo: Atlas, 2004, p. 282) e Washington de Barros Monteiro (Curso de direito civil: Direito de Família, v.2, 37ªed. São Paulo: Saraiva, 2004 p. 312).
} 
presumida, embora entendamos que ao filho esta foi estendida.

Sob essa perspectiva é que também não há como defender o legítimo interesse da mãe para propor a presente ação. Como muito bem destaca Rose Vencelau ${ }^{109}$ que "a mãe não é uma pessoa totalmente estranha à paternidade, pois no aspecto biológico o filho é a união do material genético da mãe e do pai. Se a filiação se reduzisse a esse aspecto, qualquer um poderia contestar a paternidade, bastaria provar com exames genéticos que não há consangüinidade". Contudo destaca a autora que "a questão se coloca justamente porque a paternidade é algo mais que o dado biológico, de modo que para a contestação da paternidade presumida a mãe não tem interesse tutelável, pois conseqüência alguma traz à maternidade que continua intacta".

Finalmente, ainda em relação à legitimidade ativa, cumpre assinalar que iniciada a ação negatória pelo pai presumido, seus herdeiros têm o direito de prosseguir na ação, conforme dispôs o $\mathrm{CC} / 2002$ no parágrafo único do art. 1601.

Quanto à matéria de prova cabível, o Código de 1916 estabelecia limites taxativos para que se pudesse contestar a paternidade presumida, dispondo em seu art. 340 que a legitimidade do filho havido do casamento podia ser contestada se provado que o marido se achava fisicamente impossibilitado de coabitar com a mulher dentro do período da concepção ou se há esse tempo estavam os cônjuges legalmente separados.

Em que pese tanto a doutrina ${ }^{110}$ como a jurisprudência ${ }^{111}$ terem firmado

\footnotetext{
${ }^{109}$ Op.cit., p. 151

${ }^{110}$ Assim ressalta Gustavo Tepedino (A disciplina jurídica da filiação na perspectiva civilconstitucional, cit., p.458): "Diante de tais considerações, pode-se afirmar que as restrições do Código Civil de 1916 perderam a sua justificativa axiológica a partir de 5 de outubro de 1988, seja no que tange à legitimação processual do próprio filho para a atribuição insincera da paternidade/o seja no que concerne ao prazo para a propositura das respectivas ações, seja finalmente no que respeita ao material probatório a ser oferecido em juízo."
} 
entendimento de que já não havia limites materiais para cercear a matéria de prova cabível na negatória de paternidade frente ao advento do exame de DNA e aos próprios princípios constitucionais, o Código de 2002 optou por manter alguns limites em seus artigos 1599, 1600, 1602, e 1597, V.

Portanto, segundo o $\mathrm{CC} / 2002$, terá o marido que provar que se achava fisicamente impossibilitado de coabitar com a mulher nos primeiros $121 \mathrm{ou}$ mais de 300 dias que precederam ao nascimento do filho, como no CC/1916; que não doou sêmen para inseminação artificial homóloga; que não autorizou a inseminação artificial heteróloga ou que era impotente para gerar a época da concepção (impotentia generandi).

Certamente, quanto à impotência para o coito (impotentia coeundi) é certo que esta não é suficiente para elidir a presunção de paternidade, até por que, com a utilização das técnicas de reprodução assistida, é plenamente viável, ainda que não tenha havido relação sexual, ter ocorrido fecundação. Entretanto, impende também destacar, quanto à impotência generandi, que não dispôs expressamente o legislador de 2002, na hipótese da reprodução humana assistida heteróloga, que o marido só poderá excluir a paternidade presumida, provando que não houve sua autorização. ${ }^{112}$

\footnotetext{
${ }^{111}$ No acórdão a seguir o STJ expõe esse entendimento que já vinha prevalecendo na jurisprudência: "As normas jurídicas hão de ser entendidas, tendo em vista o contexto legal em que inseridas e considerando os valores tidos como válidos em determinado momento histórico. Não há como se interpretar uma disposição, ignorando as profundas modificações por que passou a sociedade, desprezando os avanços da ciência e deixando de ter em conta as alterações de outras normas, pertinentes aos mesmos institutos jurídicos. Nos tempos atuais, não se justifica que a contestação da paternidade, pelo marido, dos filhos nascidos de sua mulher, se restrinja às hipóteses do artigo 340 do Código Civil, quando a ciência fornece métodos notadamente seguros para verificar a existência do vínculo de filiação.” (Resp. 194.866/RS - Rel. Min. Eduardo Ribeiro - Terceira Turma - Julgado em 20.04.1999, DJ de 14.06.1999, disponível em www.stj.gov.br.

${ }_{112}$ Como analisa Guilherme Calmon Nogueira da Gama. ("Reprodução Assistida Heteróloga sob a Ótica do Novo Código Civil”. In: Revista Brasileira de Direito de Família, n. 19 - Ago./Set.2003, pp.50 e 51 ) "A paternidade já havia se constituído desde a época da concepção e do início da gravidez, tal como ocorreria na hipótese de procriação carnal - pressupondo a relação sexual. No âmbito da procriação assistida heteróloga, a circunstância de não haver relação sexual faz com que devam ser considerados outros pressupostos fáticos como a vontade associada ao êxito da técnica conceptiva com
} 
O Código Civil de 2002 ainda prevê a insuficiência do adultério e da confissão materna de não ser o marido o pai de seu filho para ilidir a presunção de paternidade, conforme os artigos 1.600 e 1.602. Contudo, tais argumentos poderão ser utilizados dentro do conjunto probatório na negatória de paternidade, mas por si só não serão suficientes para instruir a ação.

Finalmente, quanto ao prazo para a sua propositura dispôs o art. 1601 ser a ação negatória de paternidade imprescritível. Aqui, podemos ressaltar que se encontra o ponto mais discutido pela doutrina, uma vez que a mudança foi radical frente ao $\mathrm{CC} / 1916$, que previa em seu art. 178 , $\S 3^{\circ}$ e $4^{\circ}$ que a ação negatória da paternidade decaía em 02 (dois) meses, contados do nascimento, se era presente o marido, e em 03 (três) meses se o marido se achava ausente, contados do dia de seu retorno a lar conjugal ou se lhe ocultaram o nascimento, da data do conhecimento do fato.

Em que pese prevalecer na jurisprudência o entendimento de que tal ação é imprescritível, antes mesmo da promulgação do CC/2002, como já ressaltado, mister se faz analisarmos sob quais argumentos tal posição é defendida, pois eles são bastante diversos.

a gravidez da mulher em nítida observância ao princípio da paternidade responsável, tal como expresso no texto constitucional (art. 226, $\S 7^{\circ}$ ). Como tem sido aceito no Direito comparado, o critério de estabelecimento da parentalidade-filiação decorrente de procriação assistida heteróloga não é o biológico no que toca ao ascendente que não contribuiu com suas células reprodutivas para a formação do filho. Desse modo, ainda que o marido pretenda impugnar a paternidade relativamente ao filho, e prove que biologicamente não é o genitor da criança concebida e nascida da sua esposa, a paternidade foi estabelecida no momento da concepção e do início da gravidez. A vontade acoplada à existência do convívio conjugal e ao êxito da técnica de procriação assistida heteróloga se mostra o elemento fundamental para o estabelecimento da paternidade que, desse modo, se torna certa, insuscetível de impugnação pelo marido. O mesmo raciocínio deve ser desenvolvido relativamente ao companheiro, com a diferença acerca da necessidade do reconhecimento - voluntário ou judicial - de paternidade. A este respeito, o Código Civil de 2002 é omisso, mas o raciocínio deve ser o mesmo da procriação carnal apenas com a substituição da relação sexual pela vontade qualificada e juridicamente responsável, e associada aos outros elementos fáticos indispensáveis - entre eles a convivência dos companheiros na época da concepção e início da gravidez". 
Ainda na vigência do CC/1916, após a Constituição de 1988 e a Lei nº 8.069/90 que dispôs em seu art. 27 que o reconhecimento da paternidade é um direito imprescritível dos filhos, o STJ ficou dividido em relação à vigência dos dispositivos do Código Civil de 1916 acerca do prazo de propositura da ação negatória pelo marido, defendendo a Terceira Turma deste Tribunal, em oposição à Quarta, que a imprescritibilidade conferida pelo art. 27 deveria ser estendida a todas as ações de estado. ${ }^{113}$

Quanto a esse primeiro argumento, inicialmente cumpre mais uma vez destacar o que o art. 27 do Estatuto da Criança e do Adolescente trata da ação investigatória de paternidade, visando proteger justamente o interesse do filho,

\footnotetext{
${ }^{113}$ EMENTA: INVESTIGAÇÃO DA PATERNIDADE. DECADÊNCIA SUPERADA. INTERPRETAÇÃO ATUAL DO $\S 3^{\circ}$ DO ART. 178 DO CÓDIGO CIVIL. "Nos tempos atuais, não se justifica que a contestação da paternidade, pelo marido, dos filhos nascidos de sua mulher, se restrinja às hipóteses do artigo 340 do Código Civil, quando a ciência fornece métodos notavelmente seguros para verificar a existência do vínculo de filiação". (Min. Eduardo Ribeiro, Resp 194.866/RS). Pelas especiais peculiaridades da espécie, admite-se a ação da paternidade, mesmo quando ultrapassado o prazo previsto no $§ 3^{\circ}$ do art. 178 do Código Civil. O aplicador da lei não deve se deixar limitar pelo conteúdo que possa ser percebido da leitura literal e isolada de uma certa regra legal, a ponto de lhe negar sentido e valor. "As decisões judiciais devem evoluir constantemente, referindo, é certo, os casos pretéritos, mas operando passagem à renovação judicial do Direito"(Nelson Sampaio).Interpretação atual do $\S 3^{\circ}$ do art. 178 do Código Civil.Recurso conhecido e provido. (RESP 146548 / GO, Rel. Min. César Afor Rocha, $4^{\text {a }}$ Turma, Data do Julgamento: 29/08/2000 DJ 05.03.2001) No entanto, embora a $4^{\mathrm{a}}$ Turma do STJ, tenha formado o entendimento de que estaria superado tal prazo, a $3^{\text {a }}$ Turma daquele Colendo Tribunal continuava entendendo que o prazo decadencial havia de ser aplicado, porém contados da data em que o marido tivesse tomado conhecimento dos fatos ensejadores da ação, conforme a decisão a seguir: EMENTA: "Paternidade. Contestação. As normas jurídicas hão de ser entendidas, tendo em vista o contexto legal em que inseridas e considerando os valores tidos como válidos em determinado momento histórico. Não há como se interpretar uma disposição, ignorando as profundas modificações por que passou a sociedade, desprezando os avanços da ciência e deixando de ter em conta as alterações de outras normas, pertinentes aos mesmos institutos jurídicos. Nos tempos atuais, não se justifica que a contestação da paternidade, pelo marido, dos filhos nascidos de sua mulher, se restrinja às hipóteses do artigo 340 do Código Civil, quando a ciência fornece métodos notavelmente seguros para verificar a existência do vínculo de filiação. Decadência. Código Civil, artigo $178, \S 3^{\circ}$. Admitindo-se a contestação da paternidade, ainda quando o marido coabite com a mulher, o prazo de decadência haverá de ter, como termo inicial, a data em que disponha ele de elementos seguros para supor não ser o pai de filho de sua esposa". (RESP 194866/RS - Rel: Min. Eduardo Ribeiro - Órgão Julgador: $3^{a}$ Turma, Data do Julgamento: 20/04/1999, DJ 14.06.1999). Disponíveis em www.stj.gov.br. Em alguns Tribunais Estaduais, como no Tribunal de Justiça do Rio Grande do Sul, precedentes adotavam o mesmo posicionamento da $3^{\text {a }}$ Turma do STJ, aplicando o $\S 3^{\circ}$ do artigo 178 do Código de 1916, com base no princípio do melhor interesse da criança.
} 
conferindo maior efetividade ao direito à paternidade e ao conhecimento da origem genética, como já apontado. Portanto, trata-se de uma ação afirmativa, cuja legitimidade é exclusiva do filho, que visa afirmar seu status ou perquirir sua origem genética.

Já a ação negatória de paternidade é uma ação negativa que visa desconstituir o status de filho proposta por outrem, ou seja, pelo pai presumido que deseja contestar a paternidade. Nesta esteira, resta claro que não é porque o art. 27 tornou a ação investigatória de paternidade imprescritível que a negatória de paternidade também deva ser, como já argumentado quando tratamos da diferença entre as ações de estado afirmativas e negativas.

Portanto, este primeiro argumento nos parece bastante frágil para que se firme um posicionamento favorável quanto à imprescritibilidade ora em análise.

Outro argumento bastante utilizado pela jurisprudência refere-se à busca da verdade real, aqui entendida como verdade biológica, argumentando-se que nem ao filho nem ao pai, tampouco à sociedade interessa manter uma paternidade fundada numa falsa declaração. Aqui, por tudo já esboçado parecenos óbvio que tal entendimento resume a "verdade" da paternidade ao vínculo biológico.

Partindo-se da premissa básica imposta pelos princípios constitucionais já aduzidos neste trabalho, que impõem a prevalência do interesse do filho nas ações de estado, pois é a ele que o texto constitucional conferiu proteção integral visando garantir o seu melhor interesse, entendemos que esta busca a “verdade real" ou seja, a origem biológica só deva ser um direito imprescritível 
para o filho, não para qualquer outro. ${ }^{114}$

Finalmente o terceiro argumento utilizado aduz que pela própria evolução do direito a regra geral das ações que envolvem o estado das pessoas é a imprescritibilidade. Mais uma vez aqui, não se diferencia as ações positivas das negativas, tampouco se prioriza o melhor interesse da criança quando se trata de ação que visa desconstituir o status de filho por outrem. Afinal, qual a proteção que está sendo garantida ao se conferir ao marido da mãe, a qualquer tempo, ou seja, conforme a sua conveniência, contestar a paternidade presumida do filho que muitas vezes ele próprio registrou? ${ }^{115}$ Além disso, não nos parece tão clara essa tendência quando analisamos outras legislações. ${ }^{116}$

\footnotetext{
${ }^{114}$ Assim destaca Zeno Veloso (Direito brasileiro da filiação e da paternidade, cit. p. 214) "A busca da verdade biológica, obviamente, tem de ter alguns limites, inclusive para garantir o que seja mais útil para a criança, para o seu equilíbrio psicológico, sua paz, tranqüilidade enfim, o que seja melhor para o seu bem, para a sua felicidade."

${ }^{115}$ Sobre essa nova realidade interessante o artigo de João Batista Villela ("O art. 1601”. In: Anais do II Congresso Brasileiro de Direito de Família. Afeto, Ética, Família e o Novo Código Civil. Belo Horizonte: IBDFAM. Belo Horizonte: Del Rey, 2004.) onde o autor ressalta que a ausência de prazo propiciará que pessoas em idade avançada possam ter sua filiação negada, por ausência de vínculo biológico, ainda que presentes os demais elementos da vida que caracterizam o rico e complexo fenômeno da paternidade. A certeza sobre a paternidade dos filhos matrimoniais somente estará assegurada após a morte do pai (e somente se ocorrida sem que este tenha iniciado a ação, porque, caso contrário, os herdeiros do impugnante poderão continuá-la).

${ }^{116}$ Como exposto por Luís Paulo Cotrim Guimarães (A paternidade presumida no direito brasileiro $e$ comparado. Rio de Janeiro: Renovar, 2001, p.192 a 213), embora defenda a tese a favor da imprescritibilidade da negatória de paternidade, podemos constatar através de sua pesquisa ao tratar da referida ação que diversas legislações mantém prazos para propositura da negatória de paternidade. A título de exemplo cita o autor o art. 244 do Código Civil italiano que dispõe: "244. L'azione di disconoscimento della paternità da parte della madre deve essere proposta nel termine di sei mesi dalla nascita del figlio. Il marito può disconoscere il figlio nel termine di un anno che decorre dal giorno della nascita quando egli si trovava ai tempi di questa nel luogo in cui è nato il figlio; L'azione di disconoscimento della paternità può essere proposta dal figlio, entro un anno dal rompimento della maggiore età o dal momento in cui viene sucessivamente a conoscenza dei fatti che rendono ammissibile il disconoscimento (...)" ou seja, para mãe o prazo é de 6(seis) meses da data do nascimento, para o pai de 1 (um) ano da data do nascimento do filho estando ou não presente e para o filho de um ano da maioridade ou da data que tome conhecimento dos fatos ensejadores da ação.(p. 207 e 208). No direito alemão expõe o autor que, conforme o BGB, o prazo é de 2 (dois) anos do nascimento do filho ou da data que o marido tome conhecimento de que o filho presumido não é seu. Já no Código Civil Austríaco o prazo é de um ano, assim como no Português.(p.203 e 204) Enfim, resta claro que ainda que disponham de prazos bem maiores do que os previstos no nosso CC/1916, as legislações modernas da família romano-germânica continuam a impor prazos para sua propositura, visando a segurança jurídica do filho.
} 
As indagações não param por aqui. Inúmeros são os casos concretos que nos deixam em estado de total perplexidade, pois sob os mais diversos argumentos dão prioridade à imprescritibilidade das ações de estado negativas, revelando uma realidade absurda, colocando o filho em situações de completa insegurança jurídica. Em nome da busca da verdade real, cabe à legislação infraconstitucional ignorar os princípios constitucionais que devem reger toda a matéria referente à filiação?

Também merece destaque a análise realizada por Rose Melo Vencelau, aduzindo que o CC/2002 estaria ferindo o princípio da unidade de filiação, tratando de forma diversa os filhos oriundos do casamento dos havidos fora dele. Pois em relação aos filhos havidos de sua mulher, permite o Código Civil em vigor que, a qualquer tempo, possa o marido provar a inexistência do vínculo biológico e extinguir a relação paterno-filial. Já se o filho é havido fora do casamento, necessário o reconhecimento voluntário ou judicial para a declaração da filiação. $\mathrm{O}$ reconhecimento judicial é imutável e o reconhecimento voluntário é irrevogável (conforme preceitua o art. 10 da Lei $\mathrm{n}^{\circ}$ 8.560/92 e o art. 1.609 do CC/2002), podendo apenas ser impugnado desde que tenha havido vício do consentimento e, mesmo assim, como expõe a autora, sujeito ao prazo geral de 4 (quatro) anos para a anulação do ato jurídico conforme o art. 178, CC2002. Dessa forma, conclui a autora que o vínculo paterno-filial estabelecido pela presunção pater is est é facilmente elidido pela vontade paterna com a demonstração de não haver consangüinidade, enquanto que o estabelecido mediante reconhecimento só pode ser impugnado excepcionalmente e dentro de um prazo legal. ${ }^{117}$

\footnotetext{
117 Op. cit., pp.159 e 160. A autora também destaca que já existe outro Projeto de Lei de $\mathrm{n}^{\mathrm{o}} 6.613 / 02$ que visa alterar o presente dispositivo com a inclusão de um prazo de 04(anos) para que o pai possa contestar a paternidade presumida pelo casamento. Nessa mesma linha de raciocínio afirma Marco Túlio de Carvalho Rocha: "Ao deixar de submeter a prazo o direito de o pai impugnar a paternidade dos filhos matrimoniais, discrimina-se estes em relação aos não-matrimoniais e adotivos, cuja paternidade não poderá ser impugnada, na vigência do novo Código Civil: a) quando houver reconhecimento judicial, em razão da imutabilidade da coisa julgada; b) quando houver
} 
Por fim, cabe destacar o entendimento defendido por Sérgio Gischkow Pereira, na esteira do PL 4946 de 2005, que não se posiciona contra a imprescritibilidade conferida à ação negatória, mas defende o reconhecimento da posse de estado de filho pela legislação brasileira, como forma de conferir proteção ao filho, entendendo que restando configurada a paternidade sócioafetiva, a ausência do vínculo biológico não terá o condão de desconstituir o vínculo paterno-filial. Portanto, para essa corrente a imprescritibilidade não conflita com os interesses dos filhos menores, pois se restar comprovada a paternidade socioafetiva, a ação do pai será repelida, por tal fundamento. Considerando-se que são planos totalmente distintos do mérito da causa. ${ }^{118}$

Dentre os projetos de lei que propõem a alteração do art. 1601 do CC/2002, percebe-se que o PL 4950 de 2005 é o que ainda confere uma maior proteção ao filho, uma vez que não amplia o rol de legitimados e, conforme o seu $\S 2^{\circ}$, reconhece a posse de estado de filho dispondo: "Não se desconstituirá a paternidade caso fique caracterizada a posse do estado de filiação, ou a hipótese do inciso V do art. 1.597”.

Já são encontradas nesta esteira, principalmente nos Tribunais do Rio Grande do Sul e Minas Gerais, decisões que priorizam a paternidade sócioafetiva fundada na posse de estado de filho, entendendo que a ausência do vínculo biológico por si só não é suficiente para anular o registro e

reconhecimento voluntário de filhos não-matrimoniais, por ser irrevogável (arts. 1.609 e 1.610, do novo Código Civil); c) quando houver adoção, por ser esta igualmente irrevogável (art. 48, da Lei $n^{\circ}$ 8.069, Estatuto da Criança e do Adolescente).Fácil concluir: a perpetuidade do prazo para impugnar a paternidade será uma espada de Dâmocles para os filhos matrimoniais! Só para estes. Seria uma punição pelos privilégios que esta classe de filhos desfrutou durante séculos em relação às demais? Vingança, ainda que tardia?"

118 Sérgio Gischkow Pereira (“A imprescritibilidade das ações de estado e a socioafetividade: repercussões do tema no pertinente aos arts. 1601 e 1614 do Código Civil”. In: (coord.) Belmiro Pedro Welter e Rolf Hanssen Madaleno. Direitos fundamentais do direito de família. Porto Alegre: Livraria do Advogado, 2004, p. 434) ressalta: “ Melhor para os próprios filhos que assim seja, pois não se chancelará uma situação falsa e hipócrita (que facilmente escorrega para a morbidez) de paternidade pela singela passagem de curto lapso de tempo, como ocorria com o art. 344 do antigo Código Civil". 
conseqüentemente desconstituir a paternidade. ${ }^{119}$

De qualquer forma não parece que tal solução atinja o cerne da questão, ou seja, confira efetivamente uma proteção integral à criança e ao adolescente, cujos interesses devam ser tratados com prioridade como impõe a Constituição Federal, como desenvolveremos mais à frente.

\subsubsection{Da ação de anulação de registro}

Tecnicamente, não se confunde a ação anulatória de registro com a negatória de paternidade, não obstante possa a negatória ser cumulada com a anulatória de registro e ambas objetivarem a desconstituição do vínculo paterno-filial, como também já ressaltado.

A ação anulatória de registro tem fundamento nos arts. 1604 e 1608 do Código Civil em vigor e no art. 113 da Lei $n^{\circ}$ 6.015/73 (Lei de Registros Públicos), podendo ser manejada tanto para desconstituir a paternidade como a maternidade, provando-se erro ou falsidade do registro de nascimento.

No que concerne à paternidade, esta ação abarca tanto as hipóteses dos filhos presumidos do casamento, como dos filhos havidos fora dele, tendo sido o registro estabelecido por presunção ou pelo reconhecimento da paternidade, ou seja, pela perfilhação.

Contudo, como destaca Caio Mário da Silva Pereira ${ }^{120}$, "no que concerne a ação anulatória do registro civil tem-se admitido um leque maior de

\footnotetext{
${ }^{119}$ Neste sentido ver decisões da nota 88 .

${ }^{120}$ Op. cit., p. 328
} 
legitimados". Nesta esteira, entende Zeno Veloso ${ }^{121}$ que a interpretação, a contrario sensu, permite que o artigo 1604 seja lido da seguinte forma: "provando-se erro ou falsidade do registro, qualquer pessoa pode vindicar estado contrário ao que resulta o registro de nascimento". ${ }^{22}$

Discute-se se a ação em questão é imprescritível. A maioria da doutrina e da jurisprudência ${ }^{123}$ entende que sim. Em posição minoritária encontramos o entendimento de que esta se sujeita ao prazo de 4 (quatro) anos do art. 178, do CC/2002, para anulação de negócios jurídicos eivados por vícios de consentimento. Contudo, ponderamos não se tratar o registro de nascimento de um negócio jurídico, como dispõe o artigo acima aludido, sendo discutível se este prazo decadencial a ele se aplica.

Para um melhor entendimento das diversas hipóteses abarcadas pela presente ação, analisaremos algumas decisões judiciais de ações negativas propostas pelo pai registral ou seus herdeiros, visando anulação do registro. Em sede jurisprudencial, encontramos basicamente duas situações mais

${ }^{121}$ Direito brasileiro da filiação e da paternidade, cit., p. 102.

${ }^{122}$ Como espelha a decisão a seguir: CIVIL E PROCESSUAL CIVIL.AÇÃO DE ANULAÇÃO DE REGISTRO DE NASCIMENTO. LEGITIMAÇÃO ATIVA. Não se cuidando de ação negatória de paternidade e sim de ação declaratória de inexistência de filiação legítima, decorrente de falsidade ideológica, é possível que ela seja intentada não só pelo suposto filho, mas também por outros legítimos interessados. Enquanto a ação negatória da paternidade é privativa do pai a ação anulatória de reconhecimento de filiação pode ser intentada por quem tenha legítimo interesse econômico ou moral. Sendo, pois, o assento de nascimento decorrente de falsa declaração, pode àquele que tenha fundado interesse em torná-lo de nenhuma conseqüência, a qualquer tempo, requerer ao juiz que assim o declare, através de pretensão regularmente deduzida. RECURSO PROVIDO". (APELACAO CIVEL $\mathrm{n}^{\mathrm{o}}$ 2004.001.09429- DES. Maldonado de Carvalho, Julgado em 05/08/2004, disponível em www.tj.rs.gov.br)

123 “Ação negatória de paternidade. Ação de nulidade de registro. Distinção. Decadência. Não podem ser confundidas a ação negatória de paternidade com a de nulidade de registro em razão de reconhecimento falso. Enquanto a primeira visa a impedir o registro do filho em nome do marido da mãe, a segunda tem por objeto desconstituir registro feito mediante falsa declaração. A negatória se sujeita ao prazo decadencial de 2 ou 3 meses (CC , art. 178, par. $3^{\circ}$ e $4^{\circ}$ ), enquanto a ação de nulidade é imprescritível. apelo provido, por maioria." (Apelação Cível no 596111963, Sétima Câmara Cível, Tribunal e Justiça do RS, Relator: Des. Sérgio Fernando de Vasconcellos Chaves, julgado em 27/11/96, disponível em www.tj.rs.gov.br) (grifos nossos) 
freqüentes em que a presente ação tem sido manejada: quando um pai registral visa anular o reconhecimento voluntário de um filho que sabia não ser seu filho biológico, alegando falsidade por ausência de vínculo biológico ou pelo pai presumido sob o argumento de que não tinha conhecimento de que era o pai biológico daquele filho, tendo sido induzido a erro por sua mulher.

No primeiro caso são dois os argumentos mais utilizados: o de falsidade nos casos de "adoção à brasileira" e o de erro ou coação nos casos de união estável ou mesmo de namoro. No caso da "adoção à brasileira, na grande maioria das vezes, às ações propostas pelo pai registral têm sido julgadas improcedentes, equiparando a adoção à brasileira ao reconhecimento voluntário ou a adoção regular e, portanto, irrevogáveis. Sustenta-se que tal contestação também seria inconcebível por violar o princípio da vedação ao venire contra factum proprium. ${ }^{124}$ Já os casos onde se alega vícios de consentimento capazes de revogar o reconhecimento voluntário, as decisões requerem uma análise mais minuciosa do conjunto probatório, havendo decisões em ambos os sentidos.

\footnotetext{
${ }^{124}$ Assim destaca Paulo Luiz Netto Lobo (Código Civil Comentado, cit., p.89 e 90) afirmando que não haverá falsidade se o declarante for o marido da mãe, sabendo não ter o filho sua origem genética, porque prevalece a presunção pater is est, cuja perfilhação foi conscientemente assumida. Assim, não poderia o autor da declaração falsa vindicar a invalidade do registro do nascimento, conscientemente assumida, porque violaria o princípio assentado em nosso sistema jurídico de vedação ao venire contra factum proprium. Conclui o autor que nas hipóteses que configuram a denominada "adoção à brasileira", ainda que de forma ilegal, atende-se ao mandamento contido no art. 227 da Constituição, afirmando que "a invalidade do registro assim obtido não pode ser considerada quando atingir o estado de filiação, por longos anos estabilizado na convivência familiar." Em relação ao venire contra factum proprium no direito brasileiro, Anderson Schreiber (A proibição de comportamento contraditório: tutela da confiança e venire contra factum proprium. Rio de Janeiro: Renovar, 2005) faz uma profunda análise das hipóteses em que a vedação a este princípio tem sido utilizada, embora não consagrado em nossa legislação. Neste sentido segue a decisão proferida pelo TJRS: "AÇÃO NEGATÓRIA DE PATERNIDADE. ADOÇÃO A BRASILEIRA. PATERNIDADE SOCIOAFETIVA. O REGISTRO DE NASCIMENTO REALIZADO COM O ÂNIMO NOBRE DE RECONHECER A PATERNIDADE SOCIOAFETIVA NÃO MERECE SER ANULADO, NEM DEIXADO DE SE RECONHECER O DIREITO DO FILHO ASSIM REGISTRADO. NEGARAM PROVIMENTO”. (APELAÇÃO CíVEL N 70003587250, OITAVA CÂMARA CÍVEL, TRIBUNAL DE JUSTIÇA DO RS, RELATOR: DES. RUI PORTANOVA, JULGADO EM 21/03/02).
} 
Ressalte-se que em algumas decisões a interpretação das expressões "erro" e "falsidade" tem sido bastante flexível. ${ }^{125}$ A verdade biológica, verificada por meio do exame de DNA, tem embasado, equivocadamente, com freqüência os pedidos de anulação dos registros de nascimento, não interpretando a regra do art. 1609 do Código Civil em vigor, em consonância com o princípio do melhor interesse do filho, que prima pela regra geral da irrevogabilidade do reconhecimento voluntário. ${ }^{126}$

Nesse sentido, muito consistente o voto proferido pelo Desembargador Célio César Paduani, do Tribunal de Justiça de Minas Gerais ${ }^{127}$, negando provimento à apelação proposta por pai registral visando anular o registro de filho que este havia reconhecido voluntariamente quando vivia com a mãe, alegando que foi induzido a erro, pois achava ser realmente o pai da criança. Chama a atenção a análise que inicialmente faz o Relator dos conceitos de “erro", "dolo" e "coação", hipóteses excepcionais em que o reconhecimento

${ }^{125}$ Neste sentido: STJ, Resp 139.590/SP, DJ 03.022003 e Resp 158.056/MS, DJ 28.08.2000.

${ }^{126}$ Caio Mário da Silva Pereira (Reconhecimento da paternidade e seus efeitos. $3^{\text {a }}$ ed. Rio de Janeiro: Forense, 1991, p.72) elucida que "uma vez pronunciada a declaração volitiva do reconhecimento, ela se desprende do foro interior do agente, para adquirir a consistência jurídica de um ato perfeito."

127 "Ab initio, cumpre destacar que o ato que o apelante pretende ver declarado nulo foi emanado de sua própria vontade. Para desconstituição de tal ato há que se verificar se a declaração do apelante deveu-se a erro, dolo, coação, simulação ou fraude. Tomando-se "erro" na acepção juridicamente corrente de substituição de uma idéia verdadeira por outra que não o é, o apelante não laborara desta forma, ao afirmar que o apelado era seu filho. Ele tinha plena consciência de todos os fatos. Muito menos poder-se-ia afirmar que sua declaração foi decorrente de dolo. Como o próprio apelante afirma, "era namorado da ré na data em que o menor nasceu, portanto, acreditando ser o pai da criança, registrou-a como seu filho". Sua declaração não foi fruto da malícia de quem quer que seja e nem objetivou causar danos a quem quer que fosse. Resta, portanto, salientar que diante do exposto acima, vê-se que o ora apelante livremente declarou sua vontade, e ,por isso, à toda evidência tal motivação jamais poderia ser qualificada como resultante de coação capaz de viciar o ato jurídico, qual seja, o registro civil do menor. Assim, de acordo com o que dispõe o art. 348 do Código Civil de 1916, lei em vigor no momento do registro e da propositura da ação, bem como o art. 113 da Lei 6.015/73, "ninguém pode vindicar estado contrário ao que resulta do registro de nascimento, salvo provando-se erro ou falsidade do registro", a serem discutidas em processo contencioso para esta anulação. Ora, diante do alhures salientado, vejo que estão ausentes os motivos ensejadores da nulidade do registro civil, vez que referido registro preenche aos requisitos formais exigidos, tendo o apelante reconhecido a paternidade de modo espontâneo, estando, assim, ausentes quaisquer vícios. Forte nessas razões, nego provimento ao recurso. É como voto". Votaram de acordo com o(a) Relator(a) os Desembargador(es): Audebert Delage e Moreira Diniz. (TJMG - Apelação Cível $\mathrm{N}^{\circ}$ 1.0512.03.009837-4/001 - Relator: Des. Célio César Paduani - Data do acórdão: 31/03/2005, Data da publicação: 03/05/2005) 
voluntário poderia ser revogado. Mostrando que tais vícios devem ser amplamente comprovados não bastando mera alegação do Apelante, nem o exame de DNA negativo, aliás, pouco relevante no caso do reconhecimento voluntário para que a paternidade seja desconstituída.

Já na hipótese de propositura de ação de anulação de registro em face do filho presumido, não é raro que a demanda seja julgada procedente, principalmente pelo fato do principal meio de prova se tratar de exame de DNA negativo e, nesse caso, o mesmo tem sido considerado prova de suma importância, justamente por ser o pai registral casado com a mãe à época do registro, sendo a fidelidade conjugal um dever do casamento.

Ainda deve-se atentar que na hipótese do filho presumido, torna-se ainda mais essencial uma profunda investigação probatória pelo julgador, pois também não é raro que o pai tenha registrado aquele filho na vigência da sociedade conjugal por sua conveniência, visando preservá-la ou mesmo evitar tornar público um provável adultério, e posteriormente, com a dissolução desta, resolve contestar a paternidade alegando a falsidade do registro pela ausência do vínculo biológico.

Percebe-se em todas as hipóteses abordadas, que raramente é feita uma ponderação para que se alcance a solução que melhor tutele o princípio da dignidade humana do filho. ${ }^{128}$ Ainda que tenha sido o pai registral enganado,

\footnotetext{
${ }^{128}$ Homenageando a filiação socioafetiva e a dignidade humana decidiu o Tribunal de Justiça do Paraná, nesse acórdão citado por Rosana Fachin ("Do parentesco e da filiação". In: (coord) Maria Berenice Dias e Rodrigo da Cunha Pereira. Direito de família e o novo código civil, 3 ed rev. e atual e ampl. Belo Horizonte: Del Rey, 2003, p.134) "1. A ação negatória de paternidade é imprescritível, na esteira do entendimento consagrado na Súmula 149/STF, já que a demanda versa sobre o estado da pessoa, que é emanação do direito da personalidade. 2. No confronto entre a verdade biológica, atestada em exame de DNA, e a verdade socioafetiva, decorrente da denominada 'adoção à brasileira' (isto é, da situação de um casal ter registrado, com outro nome, menor, como se deles filho fosse) e que perdura por quase quarenta anos, há de prevalecer à solução que melhor tutele a dignidade da pessoa humana. 3. A paternidade socioafetiva, estando baseada na tendência de personificação do direito civil,
} 
coagido ou induzido a erro, como pode tal interesse prevalecer indeterminadamente a ponto de anos mais tarde conferir a esse pai o direito de desconstituir o status do filho. E a dignidade desse filho? Apagar-lhe todo um histórico de vida, tirar-lhe o nome, tudo isso sob o argumento da prevalência da verdade real? Em nome dos interesses do pai? Onde ficam os princípios constitucionais da dignidade da pessoa humana, do melhor interesse da criança e do adolescente, da importância da família como instrumento de realização do ser humano?

Destacam os Tribunais que não interessa para ninguém, nem para a sociedade, manter uma falsa paternidade. ${ }^{129}$ Falsa desde quando? Até aquele dia em que ele se separou da mãe, decidiu realizar o exame de DNA e resolveu não querer mais prestar alimentos aquele filho, já não era ele o seu pai? Não o provia materialmente e afetuosamente? Percebe-se um certo sentimento de solidariedade do julgador com aquele pai enganado, traído. Parece que a justiça quer a todo custo achar um modo de recompensá-lo, ao menos exonerando-o do pagamento de alimentos, tirando o seu sobrenome do filho e

vê a família como instrumento de realização do ser humano; aniquilar a pessoa do apelante, apagandolhe todo o histórico de vida e condição social, em razão de aspectos formais inerentes à irregular 'adoção à brasileira', não tutelaria a dignidade humana, nem faria justiça ao caso concreto, mas, ao contrário, por critérios meramente formais", Proteger-se-iam as artimanhas, os ilícitos e as negligências utilizadas em benefício do próprio apelado."(AC 108.417-9 - 2a C.Cív. - Ac. 20.110 Rel. Des. ACCÁCIO CAMBI - acórdão unânime - Julgado em 12.12.2001)

${ }^{129}$ Como é o entendimento da decisão a seguir: "I - Na linha da jurisprudência deste Tribunal, a ação declaratória de inexistência de filiação legítima, por comprovada falsidade ideológica, é suscetível de ser intentada não só pelo suposto filho, mas também por outros legítimos interessados'. II - O art. 178, $\S 6^{\circ}$, XII do Código Civil de 1.916 tratava da ação dos herdeiros de filho falecido que viessem a postular a declaração judicial da filiação desse 'filho'. No caso, diferentemente, trata-se de ação de irmão contra irmã, fundada no art. 348 do mesmo diploma legal, requerendo a nulidade do registro dessa última. III - Nesse caso, é de aplicar-se à orientação de ser 'imprescritível o direito ao reconhecimento do estado filial, interposto com fundamento na falsidade do registro'. IV - A orientação da Segunda Seção deste Tribunal, relativamente aos prazos prescricionais nas ações de paternidade, tem sido pela interpretação restritiva. A preocupação com a insegurança para as relações de parentesco deve ceder diante do dano que decorre da permanência de registro meramente formal, atestando uma verdade que sabidamente não corresponde ao mundo dos fatos". (RESP139118/PB; RECURSO ESPECIAL 1997/0046796-1 Fonte DJ DATA: 25/08/2003 PG: 00309 Relator Min. SÁLVIO DE FIGUEIREDO TEIXEIRA, disponível em www.stj.gov.br) 
desconstituindo a paternidade. De fato, simples a solução não é, mas punir o filho também contraria frontalmente a Constituição, permitindo, mais uma vez, que os efeitos das relações conjugais atinjam a pessoa do filho, não se levando em conta o melhor interesse desse, com prioridade máxima, como impõem os princípios constitucionais regedores das relações familiares.

Nesse contexto, interessante a decisão proferida em fevereiro de 1994 pela Corte Constitucional italiana citada por Maria Celina Bodin de Moraes, em seu artigo que ressalta a importância do nome como direito da personalidade, em que foi julgado procedente o desconhecimento da paternidade, de que decorreria a perda do sobrenome, mas que, no caso em tela, tinha o interessado direito a mantê-lo, embora não mais houvesse a relação de paternidade, sob o argumento de que este representava o verdadeiro sinal distintivo com o qual ele era individualizado, conhecido, tratado e estimado no ambiente em que vivia. ${ }^{130}$

Todas essas questões mostram que perdura a era das incertezas. Como destaca Rosana Fachin ${ }^{131}$ : "De um lado, os avanços da Constituição brasileira, de outro, a força avassaladora dos fatos; na engenharia genética e na bioética, de uma parte, grandes progressos; de outra, enormes dúvidas e incertezas".

O fato é que ainda que o direito brasileiro reconheça a paternidade socioafetiva fundada na posse de estado de filho, como propõe o PL 4946 de 2005, esta solução embora de suma importância, não é suficiente para conferir a proteção integral ao filho, tutelando sua dignidade e priorizando o seu melhor

\footnotetext{
130 "A Tutela do Nome da Pessoa Humana". In: Revista Forense, v. 98, n.. 364, nov.-dez./2002, pp. 217 a 228) Ressalta ainda a Autora na mencionada sentença, $n^{\circ} 13 / 94$, que se considera que "o interessado não pretende conservar o prenome do suposto pai, mas o próprio sinal distintivo, que possui relevância e autonomia próprias, e que já faz parte de sua subjetividade como característica própria, personalíssima e projetada ao externo".

131 "Do parentesco e da filiação" in Direito de família e o novo Código Civil, cit., pp.134 e 135.
} 
interesse como impõe a Constituição atual.

Mesmo limitando-se a possibilidade da desconstituição do status de filho quando a posse deste resta configurada, a imprescritibilidade conferida à ação negatória, por si só, já o expõe. Não é difícil dimensionarmos o tormento psicológico daquele filho que após anos, quando se presume que este já possui seus referenciais selados, por razões que não se justificam se encontre diante de uma situação e exposição desnecessárias, que, sem dúvida, gerarão abalos irrecuperáveis em sua personalidade.

Não é à toa que o direito comparado embora preveja prazos menos exíguos dos que dispunha o Código de 1916, continue impondo um limite temporal às ações negativas de paternidade. Atente-se que como exposto na introdução desse trabalho, a maioria das legislações não confere ao filho a proteção que nossa Constituição vislumbrou. ${ }^{132}$

\footnotetext{
${ }^{132}$ Neste sentido Marco Túlio de Carvalho Rocha ("Prazo para impugnar a paternidade". In: Revista Brasileira de Direito de Família, n. 13, Abr-Mai-Jun/2002, p.35) pondera: "Basta aduzir que, em Portugal, o referido prazo é de 2 anos (Código Civil, art. 1.842º , na Espanha (Código Civil, art. 136) e na Argentina (Código Civil, art. 259), de 1 ano, na França, de 6 meses (Código Civil, art. 326), e que, no Brasil, o prazo para a anulação de atos jurídicos é de 4 anos. Este, a meu ver, seria um prazo razoável, a ser fixado em lei, para a impugnação da paternidade dos filhos matrimoniais, com a vantagem da uniformização."
} 


\section{CONCLUSÃO}

Ao concluir esta pesquisa resta claro que a inquietude enfrentada pelos que militam na seara do Direito de Família no que se refere ao tema da filiação tem muita razão de ser. A paternidade e a maternidade são, sem dúvida, os referenciais permanentes a partir dos quais o indivíduo constrói a sua identidade e a sua estrutura para se afirmar frente ao mundo que o cerca.

As transformações operadas pela Constituição de 1988 e implementadas pelo Estatuto da Criança e do Adolescente mudaram radicalmente o enfoque das relações parentais, hoje calcadas na responsabilidade e na solidariedade familiar. O dever do Estado, da família e da sociedade de assegurarem, com máxima prioridade, os direitos fundamentais do menor, conferindo-lhes proteção integral por se tratarem de pessoas humanas em desenvolvimento, delinearam o princípio do melhor interesse da criança com fundamento na cláusula geral de tutela da dignidade humana.

Diante desta atual realidade torna-se claro que a criança e o adolescente são vistos nas relações parentais como a parte vulnerável e logo carecedora de maior proteção, o que justificou a atuação positiva do legislador constituinte nas questões concernentes ao direito da filiação, garantindo mais proteção aos filhos e maior responsabilidade aos pais. ${ }^{133}$

\footnotetext{
${ }^{133}$ Maria Celina Bodin de Moraes. (Danos morais em família? Conjugalidade, parentalidade e responsabilidade civil. Obra em homenagem ao Prof. Caio Mário da Silva Pereira. IBDFAM/Forense, p.20, no prelo) Neste sentido também destaca Giselda Maria Ferrnandes Novaes Hironaka ("Responsabilidade Civil na relação paterno-filial. Anais do III Congresso Brasileiro de Direito de Família. Família e Cidadania - O Novo CCB e a vacatio legis. Belo Horizonte: IBDFAM/Del Rey, 2002, pp.429 e 430): “A responsabilidade dos pais consiste principalmente em dar oportunidade ao desenvolvimento dos filhos, consiste em ajudá-los na construção o da própria liberdade. Trata-se de uma inversão total, portanto, da idéia antiga e maximamente patriarcal de pátrio poder”.
} 
Ao analisarmos as ações negativas de paternidade no curso deste trabalho, muitas questões se abriram e algumas ainda se encontram sem respostas. Mas o cerne do problema emergiu de uma forma muito clara, configurando-se em uma colisão de princípios. E, portanto, ao final deste percurso voltaremos ao início dele, mais precisamente ao primeiro capítulo desta monografia, quando tratamos dos substratos que compõem a dignidade da pessoa humana sendo este o príncípio maior de nosso ordenamento jurídico.

A dignidade não se sujeita a ponderações, no entanto, os quatro subpricípios que formam seu substrato, quais sejam, a igualdade, a liberdade, a solidariedade e a integridade psico-física podem e devem ser ponderados havendo, no caso concreto, uma colisão entre eles, objetivando-se analisar qual deles deva ser sopesado em favor do outro para melhor realizar o valor da dignidade. ${ }^{134}$

No caso em tela, diversos são os argumentos invocados pelos defensores da imprescritibilidade da ação negatória de paternidade, mas o mais recorrente é de que "a ação negatória de paternidade é imprescritível, na esteira do entendimento consagrado na Súmula 149 do STF, já que a demanda versa sobre o estado da pessoa, que é emanação do direito da personalidade". ${ }^{135}$ Infere-se que aqui encontramos a primeira e talvez a maior incongruência dos defensores desta tese. O equívoco é óbvio. Como pode um direito

\footnotetext{
${ }_{134}^{134}$ Maria Celina Bodin de Moraes. (Danos morais em família?..., cit., p.24 e 25)

${ }^{135}$ AC 108.417-9 - 2a C.Cív. - Ac. 20.110 - Rel. Des. ACCÁCIO CAMBI - un. - J. 12.12.2001. Assim defende Alessandra Morais Alves de Souza e Furtado. ("Paternidade Biológica x Paternidade Declarada: Quando A Verdade Vem À Tona" in Revista Brasileira de Direito de Família - n. 13 Abr-Mai-Jun/2002, p. 19) "Usando o conceito de desbiologização da paternidade e ao argumento de que deve prevalecer a paternidade declarada, posto que o suposto pai reconheceu a paternidade livremente e que mediante a isto seria inclusive parte ilegítima para ingressar com a referida ação, esses doutrinadores e julgados adotam uma posição que, a nosso entender, fere o Princípio Constitucional da Igualdade. Entendemos que assim como é garantido ao filho o direito de conhecer sua origem biológica, mesmo que para isso seja necessário desconstituir uma paternidade anteriormente declarada, da mesma forma ao pai declarante que, de posse da verdade, demonstra o desejo de desconstituir essa paternidade que, sendo induzido a erro, reconheceu, a Justiça tem o dever de conceder-lhes o direito a ingressar com a ação".
} 
personalíssimo, indisponível e imprescritível do filho, transformar-se em um direito de outrem (do pai) e sujeitá-lo à possibilidade de ter sua condição de filho impugnada, indeterminadamente, ou enquanto seu pai viver? Como destaca Marco Túlio Carvalho da Rocha sobre esta problemática: "Inaugura-se, uma nova categoria de direitos subjetivos: o direito de ser réu!",136

Não obstante tal ponderação, abordemos alguns argumentos mais técnicos. É natural que o pai enganado, traído, induzido a erro e de posse da verdade de que não é o pai biológico como pensava ser, demonstre o desejo de desconstituir essa paternidade que reconheceu, tendo o direito de recorrer à Justiça, e esta the conceder o direito a ingressar com a ação. Sob esta ótica, não há dúvida que o princípio da liberdade do pai legitima-se através do acesso à Justiça que deve satisfazer seu direito de intentar a demanda.

Contudo, sob a ótica do filho, parte vulnerável da relação parental e processual, temos que garantir sua integridade psíquica, a qual, em razão da imprescritibilidade conferida a esta demanda, pode ser desmazelada de uma hora para outra, vindo a ter o seu histórico de vida apagado e sua identidade perdida, enfim, causando-lhe prejuízos psicológicos imensuráveis e na maioria das vezes irrecuperáveis. A propósito, como pondera João Baptista Villela: "Todos os argumentos que militam em favor da prescrição - estabilidade das relações jurídicas, os limites da memória, a segurança, a certeza, etc. - ganham aqui um especial e extremo relevo. Se a uma situação patrimonial modesta e reles já convém beneficiar com os favores da indisputabilidade prescricional, tornando-a preclusa e, portanto, imune a questionamentos, o que não dizer da paternidade, ela própria a encarnação do sólido e do permanente no universo 136 “Prazo para impugnar a paternidade". In: Revista Brasileira de Direito de Família, n. 13, Abr-Mai-
Jun/2002, p. 36. 
afetivo de cada um? Pai é o contraponto da fragilidade e da insegurança em que está irremediavelmente imersa a criança, com seus medos e desvalias". ${ }^{137}$

Assim, estamos diante de uma colisão entre dois princípios de mesma hierarquia que compõem o substrato da dignidade humana, quais sejam: o direito à liberdade do pai e a integridade psíquica do filho. ${ }^{138}$

Torna-se, portanto, imprescindível ponderarmos os interesses contrapostos de cada uma das partes, para verificar que princípio, concretamente, terá mais peso, ou seja, qual deverá ceder em favor do outro visando dessa análise emergir qual deles melhor realiza o princípio maior da dignidade da pessoa humana. ${ }^{139}$

Considerando-se a "doutrina da proteção integral" do menor, os princípios constitucionais da solidariedade familiar e do melhor interesse da criança e do adolescente, verifica-se diante da sua vulnerabilidade e dependência na relação parental, que o exercício de liberdade de ação do pai se torna abusivo a partir do momento que passou a ser vitalício, podendo, indeterminadamente, atingir a integridade psíquica do filho, que se vê diante de uma situação de total insegurança jurídica. ${ }^{140}$

Diante desta breve análise, entendemos que embora quanto à existência da norma em comento possa não caber questionamentos, o mesmo não ocorre

\footnotetext{
137 "O Modelo Constitucional da Filiação: Verdade e Superstições”. In: Revista Brasileira de Direito de Familia, n. 2, jul-ago-set/99, p.137.

${ }^{138}$ Como já destacado na nota 30, onde a Prof. Maria Celina Bodin de Moraes desenvolve esta idéia.

${ }^{139}$ Maria Celina Bodin de Moraes. (Danos morais em família..., cit., p. 9)

140 João Baptista Villela. (“O Modelo Constitucional da Filiação: Verdade e Superstições”, cit.,,p.138) "A que as estamos condenando as nossas crianças, se elas sabem ou, pior ainda, desconfiam que seu pai de hoje pode não ser o de amanhã? (...) O que, na verdade, os fautores da imprescritibilidade à outrance estão promovendo, na certa sem o desejarem, é a caça aos pais bons partidos ou aos espólios abonados, com sacrifício das relações de afeto na família. E ao preço de devassar condutas pretéritas, invadir privacidades, exumar corpos e restos, assim como trazer aos holofotes, sem compaixão nem pudor, deslizes de conduta, que porventura o tempo já curou, se o perdão antes não dissolveu”.
} 
quanto à sua aplicabilidade ao caso concreto. Sob a ótica civil-constitucional, a tábua axiológica consagrada na Constituição pelos princípios constitucionais deve ser o ponto de partida do intérprete. ${ }^{141}$ Dessa forma, no caso concreto, havendo uma norma que contrarie um princípio constitucional que regule a mesma matéria, esta deve ser afastada, aplicando-se o princípio norteador, ou seja, a técnica da subsunção ${ }^{142}$ deve ceder lugar à aplicação dos princípios constitucionais.

De fato, o choque entre princípios, no tocante ao prazo para impugnar a paternidade, deveria ter sido, precipuamente, analisado pelo legislador, como também é certo que a regra do art. 1601 veio apenas consolidar um entendimento que já prevalecia, a nosso ver, equivocadamente, na jurisprudência, que por sua vez, também defende serem as ações anulatórias de registro imprescritíveis.

Todavia, não devemos esquecer o precioso papel da doutrina como auxiliar da justiça nos hard cases, através de uma interpretação axiológica, buscando encontrar soluções para os casos em que há colisão de princípios, que diferentemente das regras não utilizam a técnica do "tudo ou nada", mas devem ser sopesados, buscando a prevalência daquele que mais adequadamente concretize o princípio constitucional da dignidade humana, como na ponderação acima realizada. ${ }^{143}$

${ }^{141}$ Luis Roberto Barroso, Interpretação e aplicação da constituição. São Paulo: Saraiva, 1999, p.147.

${ }^{142}$ P. Perlingieri (Perfis..., cit., p. 68) critica a técnica da subsunção expondo que "a ampliação da noção de direito positivo e a sua abertura para noções e valores não literalmente e não explicitamente subsuntos nos textos jurídicos permite a superação da técnica da subsunção e a prospectação mais realística da relação dialética e de integração fato-norma, em uma acepção unitária da realidade. (Por técnica da subsunção - que num tempo representava a única técnica possível correta de interpertação normativa - entende-se o procedimento de recondução do caso concreto à fattispecie abstrata prevista na norma, corno operação puramente lógico-formal.)".

${ }^{143}$ Contribuíram de forma decisiva para a distinção entre regras e princípios, Ronald Dworkin e Robert Alexy. Na dicção de Dworkin, as regras são aplicadas sob a forma do "tudo ou nada" (all or nothing), o que não sucede com os princípios. Assim, no caso de colisão entre regras, uma delas prevalece sobre a outra de forma a excluí-la. Para o autor, "se os fatos que a regra estipula estão presentes, então ou a 
Neste contexto, cumpre registrar o acórdão inédito proferido pelo Tribunal de Justiça do Rio Grande do Sul reformando a decisão julgada improcedente no primeiro grau, proposta por filho pleiteando danos morais ao pai registral pelos abalos sofridos por ter sua paternidade desconstituída e o nome perdido. Afirmou em seu voto a ilustre Relatora que "Não era dado ao réu, após ter eleito a opção de sua conveniência na época concordar com a paternidade e gerar o vínculo, inclusive dando o seu nome ao autor, posteriormente, e com o argumento pouco convincente de que "a maternidade é certa e a paternidade é presumida” (...) O réu, 'para viver em paz' assumiu a paternidade. Posteriormente, decidiu 'negar essa verdade' e, mais uma vez, adentrar o âmago dos laços biológicos. E a paz do autor, onde fica? (...) Como referido, a dor experimentada não foi resultante da paternidade afinal desvendada, mas, muito mais, do desfazimento de laços e da perda do referencial" 144

regra é válida, e nesse caso o comando que ela estabelece tem de ser aplicado, ou ela é inválida, e nesse caso ela não contribui em nada para a decisão do caso". Alexy, partindo desta consideração, afirma que os princípios, todavia, admitem uma dimensão de peso demonstrável na hipótese de colisão entre os princípios, havendo a prevalência do princípio com peso relativo maior em relação ao outro, sem que este perca sua validade. (Daniel. Sarmento. A Ponderação de Interesses, cit., p. 44)

144 “Ação de indenização por dano moral e material. Ação negatória de paternidade promovida pelo réu contra o autor, sua mãe e irmãs, não obstante soubesse o demandado, desde sempre, que o filho não era seu. Exposição desnecessária a sofrimento intenso. Danos psicológicos e desequilíbrio. Hipótese que, se não colore a figura do abuso de direito, porquanto reconhecido ser direito do réu perquirir os laços biológicos, pelo menos tipifica a imprudência na condução dos atos da vida do homem médio. Era obrigação do réu pressupor, ao tempo em que se uniu à mãe do autor e assumiu a paternidade do filho que já era gerado por aquela, sponte sua, que, se pretendesse mais além rever a atitude tomada, as conseqüências seriam de proporções consideráveis à vida do perfilhado. Se não flagrado o abuso de direito na propositura da ação negatória de paternidade - que muito insinua cupidez pela futura herança a ser repartida -, porquanto o réu tinha o direito de perquirir de sua prole, flagra-se atitude contrária aos princípios mais comezinhos da ética o selar uma paternidade de forma temerária, deixando a discussão mais detalhada para o momento da conveniência do demandado. Dano moral in re ipsa. Quantificação da indenização atentando-se à gravidade da lesão e à suficiência da reparação no caso concreto. Sentença modificada. Apelo provido. Vistos, relatados e discutidos os autos. Acordam, os magistrados integrantes da 10a Câmara Cível em Regime de Exceção do Tribunal de Justiça do Estado, à unanimidade, em dar provimento ao apelo. Custas na forma da lei”. (Apelação Cível nº 70007104326 10. Câmara Cível em Regime de Exceção - Bento Gonçalves - Rel. Dra. Ana Lúcia Carvalho Pinto Vieira - julgado em 17/06/2004 - disponível o inteiro teor do acórdão na Revista de Jurisprudência do TJRS de Dezembro de 2004) 
Diante dessa decisão, percebemos que ainda que não encontremos uma definição pacífica quanto ao prazo decadencial ideal para regular o direito do pai, que não deve ser de todo afastado, cabe destacar que, tanto na doutrina como na jurisprudência, já está sendo considerado que a própria contestação da paternidade, proposta pelo pai, poderá ensejar danos morais na pessoa do filho, quando atingir sua integridade psíquica, isto é, um dos aspectos de sua dignidade. $^{145}$

De qualquer forma, por todos os argumentos aqui aduzidos, impõe-se que limites sejam fixados nas ações negativas de paternidade, visando tornar efetiva a proteção integral ao filho que a Constituição de 88 conferiu.

Tratando-se de ação de anulação de registro do filho proposta por outrem, cumpre ressaltar que não compartilhamos da idéia de que o registro de nascimento configura-se como um negócio jurídico, entendemos que esta ação não está sujeita ao prazo decadencial do art. 178 do CC/2002. Contudo, como ressalta João Baptista Villela ${ }^{146}$, "constitui fonte de graves equívocos pensar o registro fora de seu ambiente 'semântico' próprio. O falso na semântica do registro é o que não corresponde à realidade da operação que nele se assenta. Não o que material ou ideologicamente divirja do declarado. Assim, se alguém comparece ao registro e declara a outrem como filho seu, por supor, equivocadamente, tê-lo gerado, não faz surgir um assentamento falso. $O$ assento é, ao contrário, verdadeiro e produzirá efeitos jurídicos típicos até que seja desconstituído. Se depois o declarante, de posse da informação de que o filho tem outra procedência genética, quiser invalidar o registro, não lhe basta

\footnotetext{
${ }^{145}$ Maria Celina Bodin de Moraes (Danos morais em família..., cit., p. 9) elucida que"Dano moral será, em conseqüência, a lesão, a violação, a algum desses aspectos ou substratos que compõem a dignidade humana, isto é, a violação à liberdade, à igualdade, à solidariedade ou à integridade psicofísica de uma pessoa humana. Estes princípios, porém, podem entrar em colisão entre si. Neste caso, será preciso ponderar, através do exame dos interesses em conflito, tais princípios em relação a seu fundamento, isto é, a própria dignidade humana

${ }^{146}$ João Baptista Villela. (“O Modelo Constitucional da Filiação: Verdade e Superstições”, cit., ,p.140)
} 
isso para o desconstituir. Por isso é que a um reconhecimento de filho, formalmente correto, mas que tenha sido efetuado por equivocada suposição do declarante, não se combate com o manejo da ação de falsidade do registro, senão com ação de nulidade por erro na declaração unilateral não-receptícia de vontade. Filigrana? Parece, mas não é. As hipóteses de falsidade e erro, aliás, estão expressamente discriminadas no art. 348 do Código Civil, na redação que lhe deu o Decreto-Lei ${ }^{0} 5.860$, de 30 de setembro de 1943. Tudo se determina e se esclarece, como se percebe, segundo o horizonte próprio do registro: em sede de filiação, ele não exprime, no direito brasileiro, um arco de ocorrências biológicas".

Portanto, percebe-se claramente que ainda que a ação anulatória de registro seja imprescritível, esta é uma ação que deve ser analisada de forma restrita, devendo ser manejada dentro se seu contexto, regulada pela Lei de Registros Públicos e pelo Código Civil em vigor. Neste sentido, é fundamental o papel do julgador, que deve estar atento para os conceitos de erro e falsidade no registro, pois não há nada que obrigue o registro a exprimir um fato biológico. O que ele deve espelhar é o fato jurídico que lhe deu origem, ou seja, a vontade do pai que, naquele momento, manifestou de forma livre o desejo de registrar aquele filho como seu, o que pode coincidir com o vínculo biológico ou não. Assim, o erro e a falsidade no registro só podem ser alegados em relação ao fato jurídico que lhe deu origem. A ausência de vínculo biológico, por si só, não será suficiente para ensejar a propositura da presente ação.

Já para negatória de paternidade propomos ao legislador a fixação de um prazo decadencial de um ano para a propositura da demanda. Este seria um prazo razoável, na medida que, por um lado ampara o direito à liberdade do pai por um tempo não tão exíguo como o do Código de 1916, mas por outro, 
impõe que este seja diligente, pois se há qualquer desconfiança quanto à paternidade, este terá um prazo para contestá-la, que há de ser breve. "O direito não socorre os que dormem", não devendo estar à disposição da conveniência do pai, o que na prática se associa com a dissolução da sua relação com a mãe daquele filho ou visando proteger direitos patrimoniais, como, por exemplo, fugir do dever de pagar alimentos.

Este também foi o entendimento do Ministro Barros Monteiro em seu brilhante voto vencido pelo não provimento do recurso, que tratava de ação de anulação de registro proposta pelo pai visando contestar à paternidade em relação aos filhos havidos na constância do casamento com sua ex-mulher.

Inicialmente, o ilustre Ministro distingüe a ação negatória de paternidade da anulatória de registro, alegando acertadamente que o pai deveria ter proposto ação negatória e não anulatória de registro, pois a contestação da paternidade era em relação aos filhos havidos na constância do casamento com sua ex-mulher. Assim profere em seu voto: "Conheço, pois, do recurso pela alínea "c" do admissor constitucional. Mas ao recorrente desassiste razão. É que, a despeito de rotulada a ação de "ordinária de anulação de registro de nascimento", o autor - ora recursante - está a almejar, nada mais nada menos, do que contestar a legitimidade dos filhos havidos com a sua ex-mulher na constância do casamento. (...) Afigura-se paradoxal no apelo especial interposto pelo demandante, de um lado, a assertiva de que veio a Juízo postular a anulabilidade dos registros de nascimento com base em alegado vício de vontade e, de outro, a alegação de que as ações de estado são imprescritíveis. À toda evidência que não se confundem a ação de estado e capacidade das pessoas com a ação fundada em ocorrência de vicio de consentimento, cujo regime prescricional inclusive é distinto". 
Em segundo lugar destaca que, ao contrário do que alega o demandante, a ação não é imprescritível, pois deve ser aplicado, no caso em tela, o art. 178, parágrafo $3^{\circ}$, do $\mathrm{CC} / 1916$, à época vigente, ponderando ser totalmente equivocado o entendimento quanto à imprescritibilidade da ação negatória por essa se tratar de ação de estado, invocando decisão em que Ministro Waldemar Zveiter foi Relator (Resp n ${ }^{\text {0 }}$ 89.606-SP, DJU de 09/06/97) onde este ressalta que "a ação negatória de paternidade embora cuide do estado de pessoa, não guarda qualquer relação com a de investigação de paternidade, de que cogita a Súmula n 149, do STF”.

Também pondera ser favorável aos prazos impostos pela legislação na época vigente (CC/1916), citando Orlando Gomes destacando que "são curtos os prazos para evitar que a situação do filho permaneça incerta por longo tempo. Ademais o marido que não reage prontamente, sabendo que não é seu o filho, revela insensibilidade ou indiferença, que não deve merecer amparo legal". 147

Assiste razão o ilustre Ministro em todos os seus argumentos, o que demonstra que a opção do legislador de 2002 também não é pacífica em sede jurisprudencial e embora majoritária, é calcada em argumentos totalmente equivocados como já analisamos anteriormente.

Ademais, tais posicionamentos a favor da imprescritibilidade ora em análise contrariam frontalmente os princípios constitucionais da solidariedade

147 RESP 146548 / GO QUARTA TURMA, Rel. Min. Barros Monteiro. Data do Julgamento 29/08/2000. DJ 05.03.2001. "Vistos, relatados e discutidos estes autos, acordam os Srs.Ministros da Quarta Turma do Superior Tribunal de Justiça, na conformidade dos votos e das notas taquigráficas a seguir, por maioria, conhecer do recurso e dar-lhe provimento, vencido o Sr.Ministro Relator, que dele conhecia, mas lhe negava provimento.Votaram com o Sr. Ministro Cesar Asfor Rocha os Srs. Ministros Ruy Rosado de Aguiar, Aldir Passarinho Júnior e Sálvio de FigueiredoTeixeira.'(Disponível em www.stj.gov.br) 
social e da dignidade humana, e neste ponto, como alertamos no início deste trabalho, não podemos esquecer que o direito de família encontra-se dentro da Constituição, que desenhou um Estado Democrático de Direito com fundamento na tutela da dignidade da pessoa humana, que por sua vez fundamenta o princípio do melhor interesse do filho, por analogia ao princípio do melhor interesse da criança.

Neste sentido, torna-se fundamental a manifestação do legislador para que se imponha um limite ao exercício do direito de liberdade do pai para que este não se torne abusivo em relação à integridade psíquica do filho, dirimindo-se a colisão entre os princípios ora analisados e garantindo ao menor uma proteção ampla e efetiva, priorizando-se os laços de afeto nas relações familiares. 


\section{REFERÊNCIAS}

ALMEIDA. Maria Christina. "O paradoxo da Filiação Biológica e Sócioafetiva”. Boletim do IBDFAM, Set.- Out./ 2003.

ALVAREZ, Alejandro Bugallo. Princípios informativos da relação de filiação: indagações à luz dos progressos da biotecnologia.

BARBOZA, Heloisa Helena. "O Estatuto da Criança e do Adolescente e a disciplina da filiação no código civil". In: PEREIRA, Tânia da Silva C coord.). O melhor interesse da criança: um debate interdisciplinar. Rio de Janeiro: Renovar, 2000.

. "O princípio do melhor interesse da criança e do adolescente". In: Anais do II Congresso Brasileiro de Direito de Família, A Família na Travessia do Milênio. Belo Horizonte: DeI Rey, 2000.

BARROS, Fernanda Otoni de. Do direito ao pai. Belo Horizonte: DeI Rey, 2001.

BARROSO. Luis Roberto. Interpretação e aplicação da constituição. São Paulo: Saraiva, 1999.

BODIN DE MORAES, Maria Celina. "Danos morais em família? Conjugalidade, parentalidade e responsabilidade civil". Obra em homenagem ao Prof. Caio Mário da Silva Pereira. IBDFAM/Forense, no prelo.

- Novos paradigmas do Direito Civil. Palestra proferida na Escola de Magistratura do Rio de Janeiro (EMERJ) em 20/05/2005.

- "Danos morais e relações de família". In: PEREIRA, Rodrigo da Cunha (org.) Anais do IV Congresso Brasileiro de Direito de Família. Afeto, Ética, Família e o Novo Código Civil. Belo Horizonte: IBDFAM. Belo Horizonte: Del Rey, 2004.

. Danos à pessoa humana. Uma leitura civil-constitucional dos danos morais. Rio de Janeiro: Renovar, 2003.

. "A tutela do nome da pessoa humana". In: Revista Forense. Rio de Janeiro: Forense, v. 98, n. 364, nov.-dez./2002, pp. 217 a 228.

. “O princípio da solidariedade". In: PEIXINHO, Manoel;

GUERRA, Isabela; NASCIMENTO, Firly (Orgs.). Os principios da Constituição de 1988. Rio de Janeiro: Lúmen Júris, 2001, p. 167-190. 
"Constituição e direito civil: tendências". In: Direito, Estado e

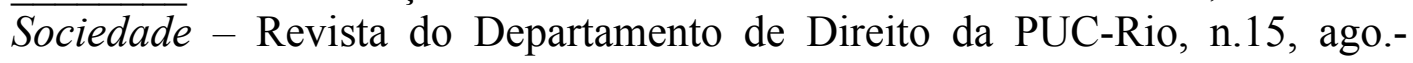
dez./1999.

- "O Direito Personalíssimo à Filiação e a Recusa ao Exame de DNA: Uma Hipótese de Colisão de Direitos Fundamentais". In: Revista Forense, vol. 343, 1998.

- "Recusa à realização do exame de DNA na investigação de paternidade e direitos da personalidade". In: BARRETTO, Vicente (org.).A nova família: problemas e perspectivas. Rio de Janeiro: Renovar, 1997.

. "A caminho de um direito civil constitucional". In: Direito, Estado e Sociedade - Revista do Departamento de Direito da PUC-Rio, 2a ed., n. 1, jul.-dez./1991.

BRAUNER, Maria Cláudia Crespo.“O pluralismo no direito de família brasileiro: realidade social e reinvenção da família”. In: Direitos fundamentais do direito de família (coord.) WELTER, Belmiro Pedro e MADALENO, Rolf. Porto Alegre: ed. Livraria do Advogado, 2004.

."Novos contornos do direito da filiação: a dimensão afetiva das relações parentais". In: Revista da AJURIS, n.78, jun/2000.

.'O pluralismo no direito de família brasileiro: realidade social e

."Considerações sobre a filiação extramatrimonial em Direito de Família francês e brasileiro". In: Revista da Faculdade de Direito, n. 27, Curitiba, 1992/93.

DELINSKI, Julie Cristine. O novo direito da filiação. São Paulo: Dialética, 1997.

DIAS, Maria Berenice e PEREIRA, Rodrigo da Cunha (coord.). Direito de Família e o novo Código Civil. 3. ${ }^{\mathrm{a}}$ ed. rev. e atual. e ampl. Belo Horizonte: Del Rey, 2003.

FACHIN, Luiz Edson. Averiguação e investigação da paternidade extramatrimonial: comentários à Lei no 8.560/92. Curitiba: Genesis, 1995.

- Estabelecimento da filiação e paternidade presumida. Porto Alegre: Sérgio Fabris, 1992. 
FACHIN, Rosana. "Do parentesco e da filiação". In: (coord) DIAS, Maria Berenice e PEREIRA, Rodrigo da Cunha. Direito de família e o novo código civil. $3^{\mathrm{a}}$ ed. rev. e atual e ampl. Belo Horizonte: Del Rey, 2003.

FEREIRA, Lucia Maria Teixeira. Tutela da filiação. In: PEREIRA, Tânia da Silva. O melhor interesse da criança: um debate interdisciplinar. Renovar: Rio de Janeiro, 2000.

FILHO, José Ribas Filho. A Construção de um novo paradigma constitucional. Rio de Janeiro: Renovar, no prelo.

GAMA, Guilherme Calmon Nogueira da. "Reprodução Assistida Heteróloga sob a Ótica do Novo Código Civil". In: Revista Brasileira de Direito de Família, n. 19, ago.- set./2003.

GIORGIANNI, Michele. O direito privado e as suas atuais fronteiras. In: Revista dos Tribunais. São Paulo: Revista dos Tribunais, ano 87, V. 747, p. 3555, jan. 1988.

GUIMARÃES, Luís Paulo Cotrim. A paternidade presumida no direito brasileiro e comparado. Rio de Janeiro: Renovar, 2001.

HIRONAKA, Giselda Maria Ferrnandes Novaes. "Responsabilidade Civil na relação paterno-filial. Anais do III Congresso Brasileiro de Direito de Família. Família e Cidadania - O Novo CCB e a vacatio legis. Belo Horizonte: IBDFAM/Del Rey, 2002.

LEITE, Eduardo de Oliveira. "Exame de DNA ou o limite entre o genitor e o pai”. In: LEITE, Eduardo de Oliveira (coord.). Grandes temas da atualidade DNA como meio de prova da filiação. Rio de Janeiro: Forense, 2000.

.'O exame do DNA: reflexões sobre a prova científica da filiação”. In: Repertório de doutrina sobre direito de família. São Paulo: Revista dos Tribunais, 1999.

LEITE, Heloísa Maria Daltro. (coord.) O Novo Código Civil do Direito de Família. Rio de Janeiro: Freitas Bastos, 2002.

LÔBO, Paulo Luiz Netto. "O direito ao estado de filiação e o direito à origem genética: uma distinção necessária”. In: Revista Brasileira de Direito de Família, n. 19, ago.- set./2003.

Código Civil comentado. Direito de família, relações de parentesco, direito patrimonial: arts. 1.591 a 1.693, vol. XVI. (coord.) AZEVEDO, Álvaro Villaça. São Paulo: Atlas, 2003. 
. "Princípio jurídico da afetividade na filiação". In: Anais do II Congresso Brasileiro de Direito de Família. A Família na Travessia do Milênio. Belo Horizonte: Dei Rey, 2000.

. Novas perspectivas no Direito de Família. Porto Alegre: Livraria do Advogado, 2000.

MONTEIRO, Washington de Barros. Curso de direito civil: Direito de Familia, v.2, 37 ed.. São Paulo: Saraiva, 2004.

NEVARES, Ana Luiza Maia. A tutela sucessória do cônjuge e do companheiro na legalidade constitucional. Rio de Janeiro: Renovar, 2004.

OLIVEIRA, Guilherme de. Critério Jurídico da Paternidade. Coimbra: Almedina, 1998.

PEREIRA, Caio Mário da Silva. Instituições de Direito Civil. v. 5. Rio de Janeiro, Forense, 2004.

Janeiro: Forense, 1991.

PEREIRA, Rodrigo da Cunha. "Pai, porque me abandonaste?" In: PEREIRA, Tânia da Silva (coord.). O melhor interesse da criança: um debate interdisciplinar. Rio de Janeiro: Renovar, 2000.

PEREIRA, Sergio Gischkow. "A imprescritibilidade das ações de estado e a socioafetividade: repercussões do tema no pertinente aos arts. 1601 e 1614 do Código Civil". In: (coord.) WELTER, Belmiro Pedro e MADALENO, Rolf Hanssen. Direitos fundamentais do direito de família. Porto Alegre: Livraria do Advogado, 2004.

PEREIRA, Tânia da Silva. "O princípio do melhor interesse da criança: da teoria à prática". In: Anais do II Congresso Brasileiro de Direito de Família. A Família na Travessia do Milênio. Belo Horizonte: DeI Rey, 2002.

.O melhor interesse da criança". In: $O$ melhor interesse da criança: um debate interdisciplinar. Rio de Janeiro: Renovar, 2000.

. Direito da criança e do adolescente. Rio de Janeiro: Renovar,

1997.

PERLINGIERI, Pietro. Perfis do Direito Civil: Introdução ao Direito Civil Constitucional. (trad. Maria Cristina de Cicco). $2^{\mathrm{a}}$ ed. Rio de Janeiro: Renovar, 2002. 
- "Normas constitucionais nas relações privadas". In: Revista da Faculdade de Direito da UERJ. Rio de Janeiro: Universidade do Estado do Rio de Janeiro, n. 6-7, p. 63-77, 1998-1999.

RASKIN, Salmo. "A análise de DNA na determinação de paternidade: mitos e verdades no limiar do século XXI). In: (coord.) LEITE, Eduardo Oliveira (coord.). Grandes temas da atualidade - DNA como meio de prova da filiação. Rio de Janeiro: Forense, 2000.

ROCHA, Marco Túlio de Carvalho. "Prazo para impugnar a paternidade". In: Revista Brasileira de Direito de Família, n. 13, Abr-Mai-Jun/2002.

RODRIGUES, Silvio. Direito Civil: Direito de família. v. 6. São Paulo: Saraiva, 2002.

ROUDINESCO, Elisabeth. A família em desordem. (trad.) André Telles. Rio de Janeiro: Jorge Zahar, 2003.

SARLET, Ingo Wolfgang. Dignidade da Pessoa Humana e Direitos Fundamentais na Constituição Federal de 1988. $2^{\mathrm{a}}$ ed. rev. e amp. Porto Alegre: Livraria do Advogado, 2002.

SANTOS, Luiz Felipe Brasil. "A posse de estado de fillho e a contestação da paternidade" artigo publicado no Boletim do IBDFAM, set.- out./2003

SARMENTO, Daniel. A ponderação de interesses na Constituição Federal. $3^{\mathrm{a}}$ tiragem, $1^{\mathrm{a} e d . . ~ R i o ~ d e ~ J a n e i r o: ~ L u m e n ~ J u ́ r i s, ~} 2003$.

SCHREIBER, Anderson. A proibição de comportamento contraditório: tutela da confiança e venire contra factum proprium. Rio de Janeiro: Renovar, 2005.

TEPEDINO, Gustavo. Temas de Direito Civil. $3^{\mathrm{a}}$. ed. rev. e atual.. Rio de Janeiro: Renovar, 2004.

“A tutela da personalidade no ordenamento civil-constitucional brasileiro". In: Temas de Direito Civil. $3^{\mathrm{a}}$. ed. rev. e atual.. Rio de Janeiro: Renovar, 2004.

- "A disciplina civil-constitucional das relações familiares. In: Temas de Direito Civil. 3a . ed. rev. e atual.. Rio de Janeiro: Renovar, 2004.

“A disciplina jurídica da filiação na perspectiva civilconstitucional". In: Temas de direito civil. $3^{\text {a }}$ ed. rev. e atual.. Rio de Janeiro: Renovar, 2004. 
."Premissas metodológicas para a constitucionalização do direito civil". In: Temas de Direito Civil. $3^{\mathrm{a}}$. ed. rev. e atual.. Rio de Janeiro: Renovar, 2004.

.Código Civil, os chamados microssistemas e a constituição: premissas para uma reforma legislativa". Revista da Faculdade de Direito da UERJ, n. 6-7,1999.

. "A disciplina civil-constitucional das relações familiares". In: BARRETO, Vicente (org.). A nova familia: problemas e perspectivas. Rio de Janeiro: Renovar, 1997.

VELOSO, Zeno."A dessacralização do DNA". In: Anais do II Congresso Brasileiro de Direito de Família. A Família na Travessia do Milênio. Belo Horizonte: Del Rey, 2000.

“Jurisprudência Comentada". In: Revista Brasileira de Direito de Família. n. 3, Out-Nov-Dez/1999.

. Direito brasileiro da filiação e da paternidade. São Paulo: Malheiros, 1997.

VENCESLAU, Rose Melo. $O$ elo perdido da filiação: entre a verdade jurídica, biológica e afetiva no estabelecimento do vínculo paterno-filial. Rio de Janeiro: Renovar, 2004.

VENOSA, Sílvio. Direito Civil: Direito de Família, 4a ed. São Paulo: Atlas, 2004.

VILLELA, João Baptista. "O Art. 1.601”. Anais do III Congresso Brasileiro de Direito de Família. Família e Cidadania - O Novo CCB e a vacatio legis. Belo Horizonte: Del Rey, 2002.

- "O modelo constitucional da filiação: verdades e superstições". In: Revista Brasileira de Direito de Família, n. 2, jul.- set./1999.

WELTER, Belmiro Pedro. "Filiação biológica e sócio afetiva: igualdade". Revista Brasileira de Direito de Família, n.14, jul.- set./2002. 
